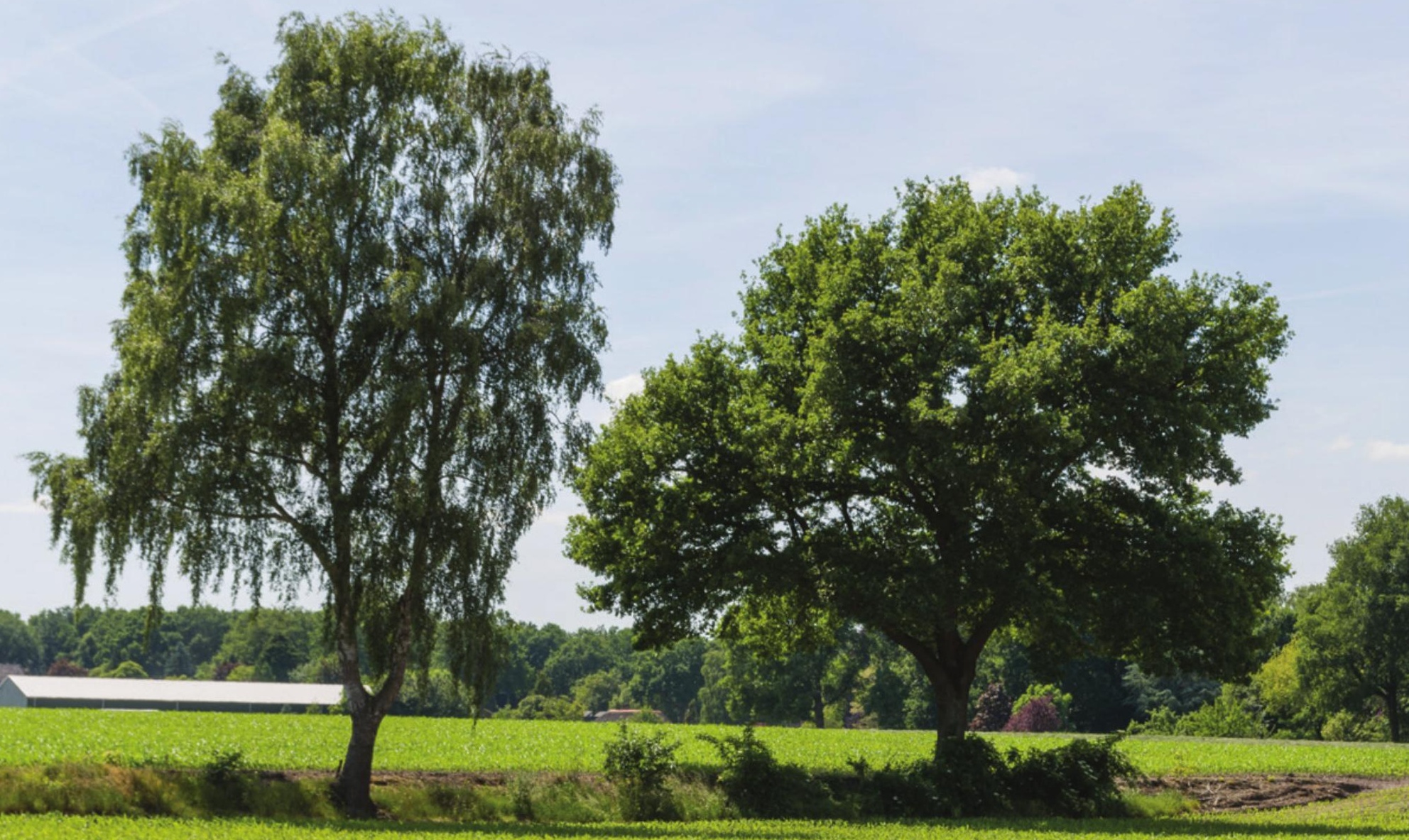

$10.34+4$ IMT ( 1n when 



\section{Beter Boeren in Kleinschalig Landschap in de gemeente Lochem}

G.J. Maas, W. Nieuwenhuizen, M. Paulissen

Dit onderzoek is uitgevoerd door Alterra Wageningen UR in opdracht van en gefinancierd door de provincie Gelderland en de gemeente Lochem.

Wageningen Environmental Research

Wageningen, april 2017

Rapport 2810

ISSN 1566-7197 
Maas, G.J., W. Nieuwenhuizen \& M. Paulissen, 2017. Beter Boeren in Kleinschalig Landschap in de gemeente Lochem. Wageningen, Wageningen Environmental Research, Rapport 2810. 76 blz.; 36 fig.; 5 tab.; 11 ref.

Met de in dit rapport beschreven cascobenadering beschikken gebiedspartijen in het vrijwillige kavelruilproject Lochem-Laren-Epse-Eefde in de gemeente Lochem over een generieke methode om naast landbouwstructuurverbetering vorm te geven aan behoud en ontwikkeling van het landschap. De cascobenadering versterkt de voor elk landschapstype unieke structuur van singels, lanen en bosjes en vergroot de landschapsecologische samenhang in het gebied. De cascobenadering hanteert landschapstype specifieke spelregels voor het behouden, kappen en aanplanten van opgaande, groene landschapselementen. Met de spelregels wordt een koers uitgezet voor de toekomstige ontwikkeling van het landschap. Voor de Gemeente Lochem en initiatiefnemers is de cascobenadering een instrument dat vooraf duidelijkheid geeft over de mogelijkheden van ingrepen in het landschap.

Trefwoorden: landschap, kavelruil, cascobenadering

Dit rapport is gratis te downloaden van http://dx.doi.org/10.18174/413663 of op www.wur.nl/environmental-research (ga naar 'Wageningen Environmental Research' in de grijze balk onderaan). Wageningen Environmental Research verstrekt geen gedrukte exemplaren van rapporten.

(9) 2017 Wageningen Environmental Research (instituut binnen de rechtspersoon Stichting Wageningen Research), Postbus 47, 6700 AA Wageningen, T 03174807 00, E info.alterra@wur.nl, www.wur.nl/environmental-research. Wageningen Environmental Research is onderdeel van Wageningen University \& Research.

- Overname, verveelvoudiging of openbaarmaking van deze uitgave is toegestaan mits met duidelijke bronvermelding.

- Overname, verveelvoudiging of openbaarmaking is niet toegestaan voor commerciële doeleinden en/of geldelijk gewin.

- Overname, verveelvoudiging of openbaarmaking is niet toegestaan voor die gedeelten van deze uitgave waarvan duidelijk is dat de auteursrechten liggen bij derden en/of zijn voorbehouden.

Wageningen Environmental Research aanvaardt geen aansprakelijkheid voor eventuele schade voortvloeiend uit het gebruik van de resultaten van dit onderzoek of de toepassing van de adviezen.

Wageningen Environmental Research Rapport 2810 | ISSN 1566-7197

Foto omslag: Steilrand langs een es nabij Gorssel (Wim Nieuwenhuizen) 


\section{Inhoud}

Woord vooraf $\quad 5$

$\begin{array}{ll}\text { Samenvatting } & 7\end{array}$

1

$\begin{array}{lr}\text { Inleiding } & 9\end{array}$

1.1 Achtergrond 9

1.2 Resultaat van de cascobenadering 9

$\begin{array}{ll}1.3 & \text { Constructieve samenwerking } \\ 1.4 & 10\end{array}$

$\begin{array}{lll}1.4 & \text { Leeswijzer } & 11\end{array}$

2

$\begin{array}{ll}\text { Opzet cascobenadering } & 12\end{array}$

2.1 Opbouw 12

2.2 Landschapstypen $\quad 12$

2.3 Landschapsdynamiek 13

2.4 Generieke bouwstenen $\quad 14$

$\begin{array}{lll}2.5 & \text { Cascokaart } & 15\end{array}$

3

$\begin{array}{ll}\text { Gebiedsopgaven \& ambitie } & 16\end{array}$

3.1 Landschap $\quad 16$

3.1.1 Gemeente Lochem 16

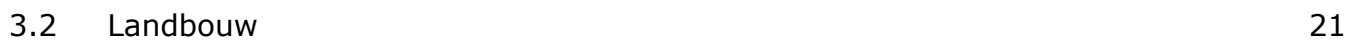

3.2.1 LTO afdeling Lochem $\quad 21$

3.2.2 ANV 't Onderholt $\quad 22$

3.3 Recreatie $\quad 24$

$\begin{array}{lll}3.4 & \text { Water \& klimaat } & 25\end{array}$

3.4.1 Opgaven \& ambities Waterschap Rijn \& IJssel 25

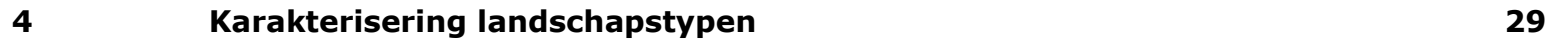

$\begin{array}{lll}4.1 & \text { Inleiding } & 29\end{array}$

4.2 Indeling landschapstypen $\quad 31$

$\begin{array}{lll}4.3 & \text { Landschapstypen rivierengebied } & 31\end{array}$

4.3.1 Uiterwaarden $\quad 32$

4.3.2 Rivierduinen 33

4.3.3 Buitendijks rivierterrassenlandschap 33

4.3.4 Rivierterrassenlandschap $\quad 35$

4.3.5 Oud rivierterrassenlandschap met esdek $\quad 35$

$\begin{array}{lll}4.4 & \text { Landschapstypen Dekzandgebied } & 37\end{array}$

$\begin{array}{lll}4.4 .1 & \text { Beekdalen } & 37\end{array}$

4.4.2 Jonge broekontginningen $\quad 39$

4.4.3 Oude broekontginningen $\quad 41$

4.4.4 Essenlandschap $\quad 42$

4.4.5 Jonge bos- en heideontginningen 44

$\begin{array}{ll}4.4 .6 \text { Kampenlandschap } & 46\end{array}$ 
$\begin{array}{lll}5.1 & \text { Generieke bouwstenen } & 49\end{array}$

5.2 Bouwstenen per landschapstype en landschapsdynamiekklasse $\quad 51$

5.2.1 Essenlandschap 52

5.2.2 Kampenlandschap 54

5.2.3 Beekdallandschap 55

5.2.4 Jonge Broekontginning 57

5.2.5 Oude broekontginningen $\quad 58$

5.2.6 Jonge bos- en heideontginningslandschap 58

5.2.7 Uiterwaarden $\quad 59$

$\begin{array}{ll}5.2 .8 \text { Rivierduinen } & 61\end{array}$

5.2.9 Rivierterrassenlandschap $\quad 62$

5.2.100ud rivierterrassenlandschap met esdek $\quad 62$

$\begin{array}{lll}5.3 & \text { Compensatie } & 63\end{array}$

5.3.1 Kwaliteitsladder 63

6

$\begin{array}{lll}6.1 & \text { Landschap in ontwikkeling } & 65\end{array}$

$\begin{array}{lll}6.2 & \text { De cascokaart } & 67\end{array}$

$\begin{array}{ll}\text { Literatuur } & \mathbf{7 2}\end{array}$

$\begin{array}{lll}\text { Bijlage } 1 & \text { Bestemmingsplan Buitengebied } & 73\end{array}$ 


\section{Woord vooraf}

'Beter Boeren' voor een toekomstbestendig landschap

Voor u ligt het rapport 'Beter Boeren in Kleinschalig Landschap in de gemeente Lochem'. Een stuk waar ik met recht trots op ben! Samen met gebiedspartijen en een klankbordgroep hebben we deze aanpak ontwikkeld.

Het project 'Beter Boeren in Kleinschalig Landschap' is gestart vanuit de wens om binnen het vrijwillige kavelruilproject Lochem-Laren-Epse-Eefde bij te dragen aan de ontwikkeling van het landschap. Met hulp van de Provincie Gelderland en Projecten LTO Noord zijn we in de gemeente Lochem aan de slag gegaan om deze ambitie te verwezenlijken. Om aan alle wensen tegemoet te komen, is een gebiedsproces vormgegeven samen met de LTO Noord afdeling Lochem, het Waterschap Rijn en IJ ssel, de agrarische natuurvereniging 't Onderholt en een aantal natuurorganisaties.

Elk landschapstype in onze gemeente kent een eigen structuur en heeft een bepaalde belevingswaarde. Deze diversiteit vormt het landschap waar we met elkaar in wonen, werken en recreëren en waar we trots op zijn. Waar dat kan willen we kwetsbare en kwalitatieve belangrijke elementen in dit landschap zoals bomenrijen en steilranden behouden. Toch kunnen we niet alleen naar het verleden kijken. We willen ook ruimte bieden aan agrarische ondernemers om elementen te verplaatsen om zo mee te bouwen aan een robuust en toekomstbestendig landschap. 'Beter Boeren in Kleinschalig Landschap' maakt dat mogelijk!

Wij denken dat we met dit plan een instrument hebben ontwikkeld dat enerzijds inzet op behoud en ontwikkeling van het landschap waar we met elkaar zuinig op zijn en dat anderzijds mogelijkheden biedt voor de toekomstgerichte landbouw!

Bert Groot Wesseldijk

Wethouder van Lochem

April 2017

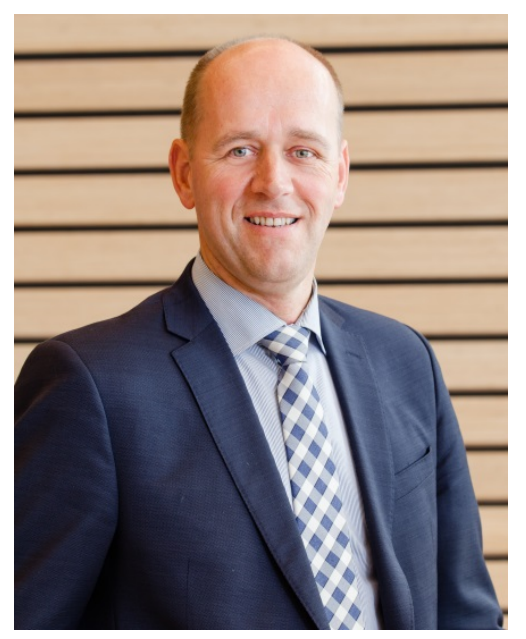




\section{Samenvatting}

Gebiedspartijen in het vrijwillige kavelruilproject Lochem-Laren-Epse-Eefde (Gemeente Lochem) zijn overeengekomen het concept van Beter Boeren in Kleinschalig Landschap bij het kavelruilproces te hanteren. Deze aanpak, ook wel bekend onder de naam 'cascobenadering', is door Alterra Wageningen UR samen met agrariërs (LTO) en gemeenten in het Nationaal Landschap NoordoostTwente ontwikkeld.

De cascobenadering is een methode die de schaalvergroting in de landbouw gebruikt als een impuls om de kwaliteit van landschappen te versterken. Het uitgangspunt is het herkennen van de belangrijkste structuren die het karakter van het landschap vormgeven. Binnen het projectgebied zijn elf verschillende cultuurlandschappen onderscheiden: vijf landschappen in het rivierengebied en zes in het dekzandgebied. De cascokaart geeft aan welke opgaande groene landschapselementen de 'dragers' van deze agrarische cultuurlandschappen zijn. De cascostructuren zijn kenmerkend voor de diverse landschappen en moeten behouden worden om de identiteit van het Lochemse landschap te bewaren. Anderzijds geeft de cascokaart aan agrarische ondernemers inzicht welke houtwallen, singels of bomenrijen in het kader van landbouwstructuurversterking mogen vervallen om deze vervolgens elders in het gebied opnieuw aan te leggen (compensatie) volgens vooraf overeengekomen spelregels.

Voor het projectgebied is met de gebiedspartijen afgesproken dat opgaande landschapselementen die vervallen, een-op-een gecompenseerd worden. Dat betekent dat het landschap er netto niet op achteruitgaat. Een uitzondering op deze regel vormen de gebieden die binnen het Nationaal landschap Graafschap vallen. Hiervoor geldt een compensatiefactor 1:1,5.

De locaties voor compensatie van opgaande landschapselementen hangen nauw samen met het type landschap en de veranderingen die in het landschap hebben plaatsgevonden (landschapsdynamiek). In landschappen met weinig of matige veranderingen draagt compensatie bij aan de versterking van de bestaande landschapsstructuur. In landschappen met een hoge dynamiek wordt voorgesteld oude landschapsstructuren gedeeltelijk los te laten en te compenseren langs de bestaande natte infrastructuur van doorgaande waterlopen en beken en op steilranden langs essen. Het Waterschap Rijn en IJssel (WRIJ) heeft een model ontwikkeld voor het eenzijdig beplanten (zuidzijde) van deze natte structuren. Uitgangspunt voor het waterschap (WRIJ) is wel dat compensatie vanuit de cascobenadering alleen gebruikt mag worden bij waterlichamen met lage ambitie, volgens de Kaderrichtlijn Water (KRW). Belangrijke voorwaarden voor het toepassen van dit model is dat op de betreffende watergang geen KRW-opgave rust en dat aan de tegenoverliggende zijde van de watergang of beek een 4 meter breed onderhoudspad kan worden gerealiseerd.

De wijze waarop de compensatie uitgevoerd moet worden, is vastgelegd in een aparte notitie 'Richtlijnen Objectivering Casco Lochem' (Gemeente Lochem, 2017). Deze notitie geeft richtlijnen voor het bepalen van afmetingen van de bestaande en nieuwe elementen en criteria voor de kwaliteit. Voor het creëren van verbindingen tussen aangrenzende percelen ten koste van landschapselementen zijn in dit rapport maatvoeringen opgenomen.

In het studiegebied is voldoende ruimte voor structuurversterking van de landbouw in de gebieden die niet onder het bestaande reguliere (inter)nationaal natuur- en landschapsbeleid vallen (Gelders Natuurnetwerk, Natura 2000, Nationaal landschap). Het huidige landschap vormt in de regel geen belemmering voor een structuurversterking. De omvang van de percelen, dat wil zeggen de ruimte tussen de landschapselementen, is in het algemeen voldoende voor een effectieve en efficiënte landbouw binnen de kaders die in het gebiedsproces van de cascobenadering zijn afgesproken. In situaties waar dit niet het geval is, voorziet de cascobenadering in een adequate oplossing. 
In deze zogenaamde 'witte' gebieden, waar geen specifiek beleid is geformuleerd voor natuur of landschap, is er juist vanuit het landschap geredeneerd een sterke behoefte aan landschapsstructuurversterking. Dit draagt niet alleen bij aan een de landschapskwaliteit en -beleving in het gebied zelf, maar vergroot ook de ecologische samenhang op regionale schaal, voor soorten die opgaande beplanting gebruiken om zich langs te verplaatsen. Het model van het Waterschap Rijn en IJssel voor agrarisch water-/natuurbeheer kan hier een grote bijdrage aan leveren. Ook voor de landbouw kan dit model aantrekkelijk zijn, omdat het tot een (bescheiden) areaalvergroting leidt en ruimte schept om landschapselementen te verplaatsen. Door de compensatie van landschapselementen te situeren langs de oost-west georiënteerde structuur van beekdalen, worden de landgoederen van Verwolde en Ampsen via een informeel landschappelijk netwerk verbonden met de Gorsselsche heide en de uiterwaardennatuur langs de IJssel.

De vrijwillige kavelruil Lochem-Laren-Epse-Eefde zal naar verwachting minder verplaatsingen van landschapselementen door compensatie opleveren dan wenselijk is om de voorgestelde landschapsstructuurversterking te kunnen realiseren. Daarvoor zijn aanvullende initiatieven nodig. 


\section{$1 \quad$ Inleiding}

\section{$1.1 \quad$ Achtergrond}

\section{Landschapsontwikkelingsvisie als uitgangspunt}

De landschapsontwikkelingsvisie van de gemeente Lochem spreekt van een landschap om trots op te zijn en signaleert tegelijkertijd spanningen tussen ontwikkelingen in de landbouw en de kwaliteit van het landschap. Het opheffen van deze spanning wordt in de Landschapsontwikkelingsvisie verwoord als: "het vinden van een duurzame balans tussen landschap en maatschappelijke activiteiten die in het landschap plaatsvinden" (Duenk \& ten Cate, 2009). Om die ambitie waar te kunnen maken, is meer nodig dan reguliere regels voor kap en aanplant, zoals die nu in de Algemeen Plaatselijke Verordening (APV) van de gemeente staan. Die huidige regels geven geen antwoord op de vraag: waar mogen opgaande groene landschapselementen weg en waar moeten ze juist versterkt worden? Met andere woorden, de regels in de APV geven geen richting aan in de wijze waarop het agrarisch cultuurlandschap versterkt kan worden.

\section{Aanleiding: cascobenadering \& vrijwillige kavelruil versterken elkaar}

Met de start van de vrijwillige kavelruil in het gebied Lochem-Laren-Epse-Eefde, ontstond de mogelijkheid om naast de landbouwstructuur, ook het landschap in het gebied te verbeteren. Het projectgebied voor de vrijwillige kavelruil is ca. 7300 hectare groot en ligt geheel in de Gemeente Lochem. Stichting Effectieve Verkaveling in Gelderland (STEVIG) heeft de mogelijkheden voor kavelruil volgens de methode Verkavelen voor Groei in het gebied verkend (zie voor meer informatie: www.verkavelenvoorgroei.nl). LTO-Noord heeft daarbij het initiatief genomen om in dit kavelruilproject het concept van Beter Boeren in Kleinschalig Landschap te hanteren. Het uitgangspunt van dit concept is ruimte bieden aan toekomstgerichte landbouw en tegelijkertijd het groene karakter van het Lochemse landschap versterken. Deze aanpak, ook wel bekend onder de naam 'Cascobenadering', is door Alterra Wageningen-UR samen met agrariërs en gemeenten in NoordoostTwente ontwikkeld en er is inmiddels in die regio veel ervaring mee opgedaan (Maas \& Boers 2010 \& Nieuwenhuizen \& Maas, 2012). De gemeente Lochem en de provincie Gelderland hebben dit initiatief van LTO Noord ondersteund en hebben de ontwikkeling van de cascobenadering in gang gezet.

Het doel van de cascobenadering is het leveren van een methode die de schaalvergroting in de landbouw gebruikt als een impuls om de kwaliteit van landschappen te versterken. Het uitgangspunt is het herkennen van de belangrijkste structuren die het karakter van het landschap vormgeven. Het robuuste landschappelijke casco dat hiermee ontstaat, kan door (agrarische) ondernemers, buitenlui en gemeenten gebruikt worden om richting te geven aan de ontwikkeling van het landschap.

\section{Bredere toepassing van de cascobenadering}

Hoewel de vrijwillige kavelruil in het gebied Lochem-Laren-Epse-Eefde de aanleiding was, kan de cascobenadering gezien worden als een brede benadering voor de omgang met landschap voor de gehele gemeente Lochem. Dit is wat de verschillende gebiedspartijen die meegewerkt hebben aan de cascobenadering zeggen over de toepassingsmogelijkheden voor de toekomst: 'In principe is de cascobenadering voor de gehele gemeente toepasbaar.'

\subsection{Resultaat van de cascobenadering}

\section{Gedetailleerde kaarten geven richting en duidelijkheid}

De kaart met opgaande groene landschapselementen, die onderdeel uitmaakt van de cascobenadering, geeft agrarische bedrijven inzicht of een houtwal of singel mag vervallen om deze vervolgens elders in het gebied opnieuw aan te leggen, volgens de spelregels van het casco. Anderzijds geeft de cascobenadering aan welke opgaande groene landschapselementen de 'dragers' 
van het agrarische cultuurlandschap zijn. Deze cascostructuren zijn kenmerken van het Lochemse landschap en om die reden moeten ze behouden worden om de identiteit van het Lochemse landschap te bewaren. Ten slotte geeft de cascobenadering ook handvatten voor de ontwikkeling van 'nieuwe' landschappen in samenhang met andere opgaven (water, natuur \& infra) in het gebied.

De gemeente Lochem kan met de uitgewerkte cascobenadering voor het STEVIG-gebied (zie figuur 1.1) ervaring opdoen met deze aanpak in de praktijk. Op dit moment zal de cascobenadering dus alleen functioneren voor dit gebied van de vrijwillige kavelruil. In potentie is de cascobenadering geschikt om voor het gehele gemeentelijke buitengebied richting te geven aan de ontwikkeling van het landschap. De cascobenadering is zo opgezet dat deze past binnen het bestemmingsplan buitengebied.

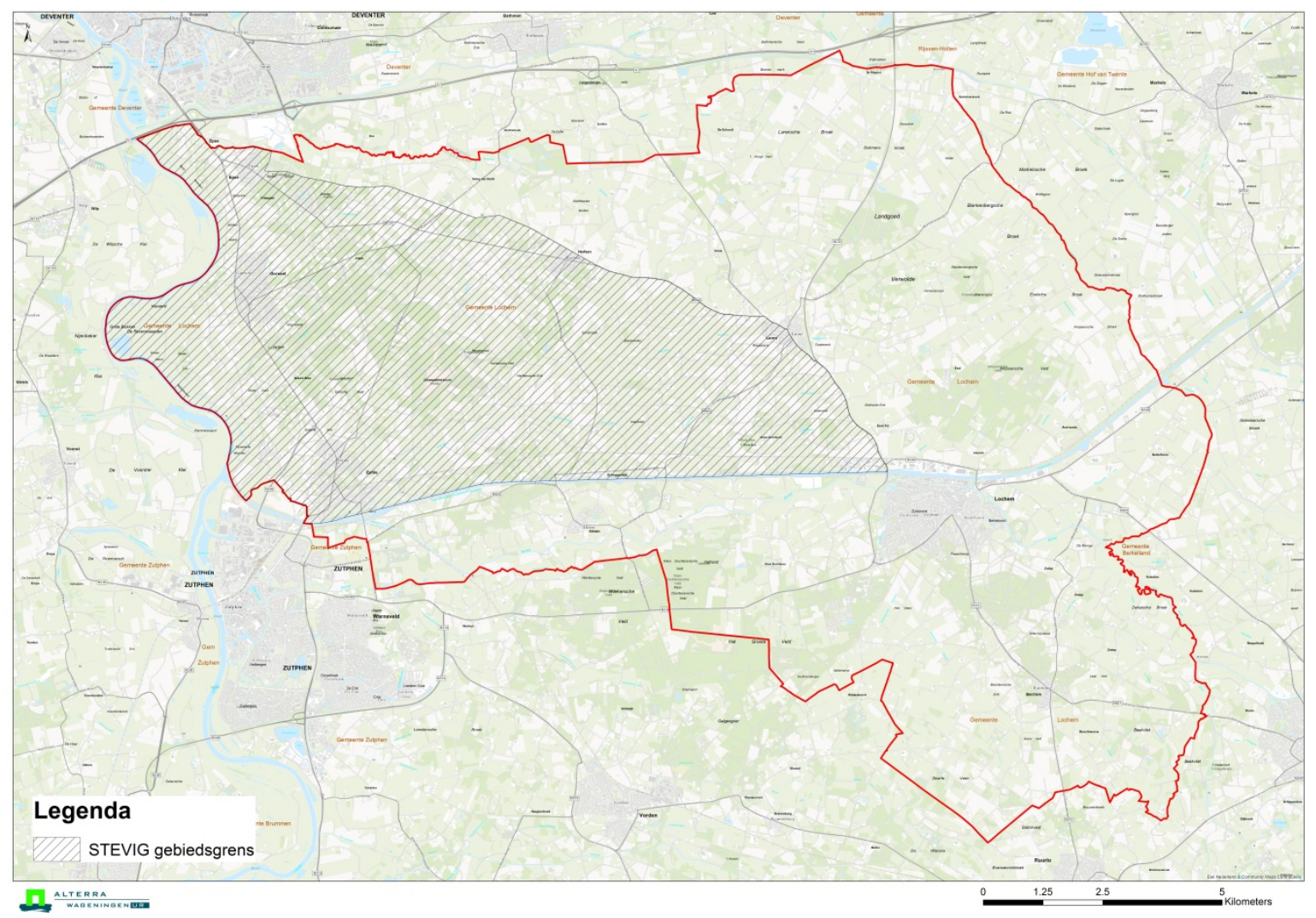

Figuur 1.1 Ligging van het STEVIG-gebied in de gemeente Lochem.

\subsection{Constructieve samenwerking}

Het voorliggende rapport met bijbehorend cascokaart is mede het resultaat van een constructieve samenwerking van de bij het gebiedsproces betrokken partijen in de begeleidingscommissie en de klankbordgroep. De begeleidingscommissie bestond uit de volgende personen:

- Ramon Hesselink namens LTO afdeling Lochem

- Karel Hesselink namens het Waterschap Rijn \& IJssel

- Herman Menkhorst namens ANV 't Onderholt

- Gerard de Ruiter namens de vertrouwenscommissie van het kavelruilproject

- Anne Stortelder namens de Gemeente Lochem

De begeleidingscommissie werd voorgezeten door Saskia Scheer van LTO-projecten

In de klankbordgroep waren de volgende organisaties vertegenwoordigd:

- De Bomenstichting

- IVN afdeling Noord-Midden Achterhoek

- Stichting Natuur in de Graafschap 
De projectleiding bij de Gemeente Lochem was in handen van Jip ten Barge. Het Alterra-projectteam bestond uit Maurice Paulissen, Wim Nieuwenhuizen en Gilbert Maas (projectleider).

\subsection{Leeswijzer}

Na de inleiding (Hoofdstuk 1) waarin de aanleiding, het doel en de achtergronden van deze studie worden beschreven, volgt in hoofdstuk 2 een korte uiteenzetting over de cascobenadering. De stappen die genomen zijn om de cascobenadering uit te werken, vormen de hoofdstukken in dit rapport. Zo beschrijft hoofdstuk 2 niet alleen de methode, maar ook de landschapstypen en landschapsdynamiek, die samen een basis vormen voor de cascobenadering.

Hoofdstuk 3 is een weergave van de gesprekken die we met gebiedspartijen hebben gevoerd om de ambities en opgaven in kaart te brengen. De generieke bouwstenen in hoofdstuk 5.1 zijn het resultaat van deze consultatie.

In hoofdstuk 4 worden de 11 verschillende agrarische cultuurlandschapstypen beschreven. De kenmerken per landschapstype worden in hoofdstuk 5.2 vertaald naar landschap-specifieke bouwstenen voor de cascobenadering. In hoofdstuk 5.3 worden de regels voor compensatie behandeld. De landschapsdynamiekkaart en de cascokaart worden gepresenteerd en toegelicht in hoofdstuk 6 en ten slotte volgen in hoofdstuk 7 de conclusies en aanbevelingen. 


\section{$2 \quad$ Opzet cascobenadering}

\subsection{Opbouw}

\section{Stappen om tot het casco te komen}

Elk landschapstype in de gemeente Lochem heeft een eigen kenmerkende structuur van opgaande beplantingen. Deze structuur is het casco van het landschap. De mate waarin dit casco nog intact is, is afhankelijk van de landschapsdynamiek, de ontwikkeling die de landschappen in de tijd hebben doorgemaakt. De combinatie van landschapstype en dynamiek vormt het vertrekpunt voor de cascobenadering.

Hoe de cascobenadering tot stand is gekomen, kan het best omschreven worden door de stappen die doorlopen zijn in chronologische volgorde te zetten:

1. Landschapstypen in kaart brengen

2. Landschapsdynamiek in kaart brengen

3. Bouwstenen per landschapstypen opstellen

4. Landschapstypen, dynamiek \& bouwstenen combineren tot cascokaart

Elke stap is gedaan in samenspraak met gebiedspartijen in de gemeente Lochem.

\subsection{Landschapstypen}

\section{Landschapstypen tonen de ontginningsgeschiedenis}

Het vertrekpunt van de cascobenadering zijn de landschapstypen. Wie naar de topografische kaart van de gemeente Lochem kijkt, kan veel verschillende cultuurlandschapstypen onderscheiden. Deze variatie in landschappen is ontstaan doordat bewoners het landschap door de eeuwen heen juist daar ontgonnen waar de natuurlijke milieuomstandigheden op dat moment goede bestaansmogelijkheden boden voor bewoning en landbouw. Zo zijn er landschappen die al vele honderden jaren geleden in cultuur gebracht zijn, maar ook landschappen die pas in de twintigste eeuw intensief in cultuur gebracht zijn. De kaart met landschapstypen is het eerste onderdeel van de cascobenadering.

\section{Detaillering van de landschapstypen uit de landschapsontwikkelingsvisie}

In het kader van dit project is een nieuwe indeling en begrenzing van de landschapstypen gemaakt. De bestaande landschapsindeling uit het landschapsontwikkelingsplan (Duenk \& Ten Cate, 2009) was onvoldoende gedetailleerd voor de toepassing van de cascobenadering.

Voor de kartering van de landschapstypen is gebruikgemaakt van historische kaarten uit ca. 1900 (Bonnekaart), de Bodemkaart van Nederland (1:50.000) en de Geomorfologische kaart van Nederland (1:50.000). Tijdens het begrenzen van de landschapstypen is gelet op het (historisch) landgebruik, het verkavelingspatroon, de kavelvorm en -grootte, de beplantingsstructuur, de bodem en het reliëf. De grenzen tussen de landschapstypen sluiten zo veel mogelijk aan bij de moderne topografie. Deze methode voor landschapsclassificatie is ontleend aan De Bont (2008). De grondgedachte achter de classificatie is dat elk oorspronkelijk natuurlijk milieu een op dat milieu toegespitste agrarische ontginningsgeschiedenis kent. De specifieke elementen en patronen die samenhangen met de wijze van ontginning komen binnen de onderscheiden landschapseenheid bovengemiddeld voor en zijn op topografische kaarten herkenbaar. De Bont onderscheidt voor Nederland elf hoofdlandschapstypen en meer dan vijftig sub-landschappen (Dirkx \& Nieuwhuizen, 2013).

Op grond van de geologische ontstaansgeschiedenis delen we het STEVIG-gebied allereerst in 2 hoofdlandschappen in:

- rivierenlandschap

- dekzandlandschap 
Binnen deze hoofdlandschappen onderscheiden we vervolgens de verschillende landschapstypen die het gevolg zijn van de wisselwerking tussen natuurlijke en menselijke landschapsvormende factoren. Deze landschapstypen vormen het uitgangspunt voor de cascobenadering.

Binnen het rivierenlandschap onderscheiden we vijf verschillende landschapstypen (zie figuur 4.3):

- Uiterwaardenlandschap

- Rivierterrassenlandschap (buitendijks)

- Rivierduinenlandschap

- Rivierterrassenlandschap (binnendijks)

- Rivierterrassenlandschap met esdek

Binnen het dekzandgebied worden zes landschapstypen onderscheiden:

- Beekdallandschap

- Oude broekontginning

- Jonge broekontginning

- Bos- en heideontginning

- Kampenlandschap

- Essenlandschap

\subsection{Landschapsdynamiek}

\section{Verschillen in dynamiek per deelgebied}

Zoals bij de landschapstypen staat beschreven, hebben onderdelen van het gebied verschillende ontwikkelingen doorgemaakt die ervoor zorgen dat de landschapstypen niet meer overal even herkenbaar zijn. In die delen waar de ruimtelijke dynamiek groot is geweest, zijn veel karakteristieke kenmerken als opgaande beplanting, kavelgrenzen en steilranden verdwenen. In andere delen van het gebied is de dynamiek kleiner geweest, waardoor meer van de oorspronkelijke kenmerken van het landschapstype bewaard gebleven zijn.

Het landschap ten westen van Laren bijvoorbeeld is in de $20^{\text {ste }}$ eeuw sterk veranderd. Dat is goed te zien als we de situatie uit 1900 met die van 2000 vergelijken. In figuur 2.1 is dit in 3D-animaties van kaarten uit beide periodes weergegeven.

1900

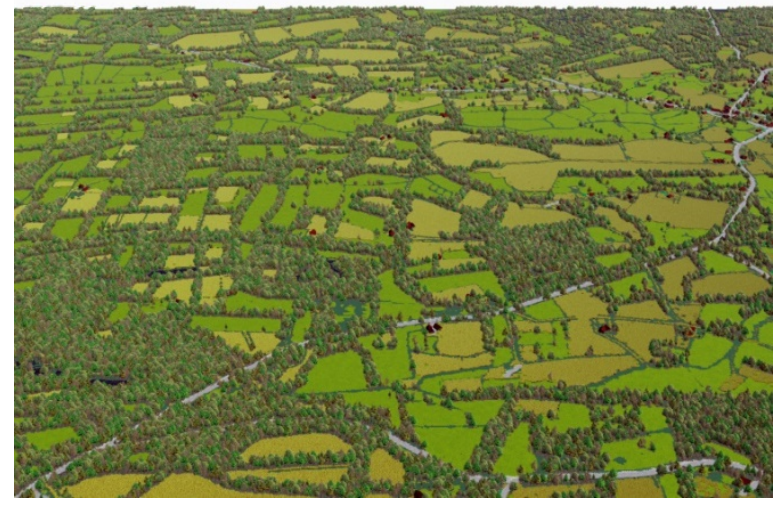

2000

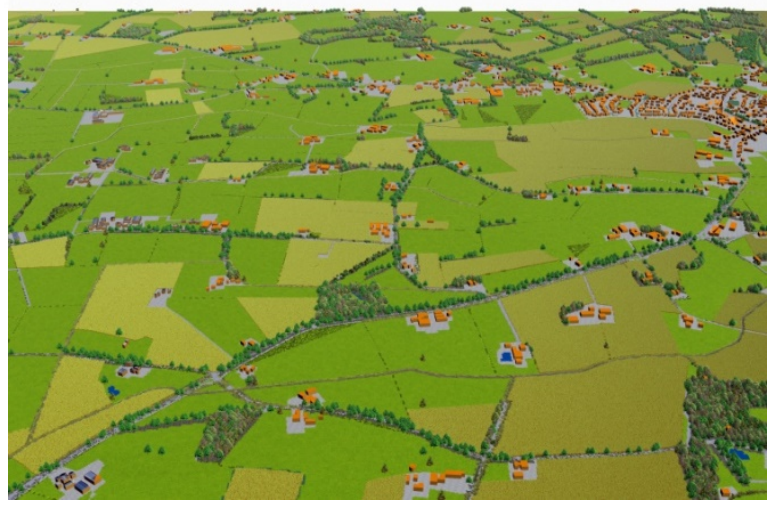

Figuur 2.1 Landschapsdynamiek in de $20^{\text {ste }}$ eeuw ten westen van Laren (Laren ligt in beide figuren in de rechter bovenhoek).

Deze landschapsdynamiek wordt in de cascobenadering gebruikt om te bepalen of de herkenbaarheid van de oorspronkelijke landschappen versterkt kan worden (in geval van lage dynamiek) of dat juist gezocht moet worden naar nieuwe structuren die in feite een nieuw landschap vormen (in geval van hoge dynamiek). Daarmee is de dynamiekkaart bepalend voor de keuze welke elementen tot het casco behoren en welke elementen verplaatst kunnen worden. 


\section{Drie dynamiekklassen}

De landschapsdynamiek kunnen we aflezen uit veranderingen in de structuur, het casco of het raamwerk van het landschap. Elk landschapstype wordt gekenmerkt door een hoofdstructuur bestaande uit de infrastructuur en een ontginningspatroon: regelmatige of onregelmatig blokken of een strokenverkaveling. Op een lager niveau wordt door dichtheid van het netwerk van lijnvormige elementen tussen de hoofdstructuur de schaal van het landschap bepaald. Deze is net als het landschapstype gekoppeld aan de abiotische condities. Naarmate een gebied natter was, werd om het waterpeil te kunnen beheersen de afstand tussen de sloten en greppels kleiner en daarmee het landschap kleinschaliger van structuur.

Om zicht te krijgen op de landschapsdynamiek is een kaart gemaakt waarop het STEVIG-gebied is ingedeeld in drie klassen van dynamiek:

- Laag: hoofdstructuur gaaf, secundaire structuur weinig veranderd tot onveranderd

- Matig: hoofdstructuur weinig veranderd, secundaire structuur sterk veranderd

- Hoog: hoofdstructuur en secundaire structuur matig tot sterk veranderd

Om deze dynamiek te bepalen, is gekeken naar de veranderingen in de landschapsstructuur in de periode 1900 tot heden. Deze periode is om twee redenen gekozen. In de eerste plaats is dit de periode waarin het historische agrarische cultuurlandschap optimaal was ontwikkeld en in de tweede plaats zijn er goede kaartbronnen (Bonnekaart) voor deze periode beschikbaar. De grootste veranderingen in het landschap zijn vanaf 1960 opgetreden door ontwikkelingen in de agrarische bedrijfsvoering en daarmee ook in het landschap.

\section{Dynamiek bepaalt de ontwikkelingsrichting}

De combinatie van landschapstypen, dynamiek en bouwstenen (zie paragraaf 5.1) bepaalt in welke gebieden primair behouden en/of versterken van opgaande groene landschapselementen aan de orde is en waar er, volgens de spelregels van de cascobenadering, ruimte is voor landbouwstructuurverbetering en ontwikkeling van nieuwe landschapsstructuren.

Hiervoor wordt de volgende indeling gehanteerd:

- Lage dynamiek: behouden, geen ruimte voor structuurversterking landbouw

- Matige dynamiek: versterken hoofdstructuren landschap en beperkte ruimte structuurversterking landbouw

- Hoge dynamiek: veel ruimte voor structuurversterking land in combinatie met nieuwe landschapsstructuren

In hoogdynamische landschappen zijn robuuste elementen op (nieuwe) hoofdstructuurlijnen te verkiezen boven lokaal herstel van kleinschalig agrarisch cultuurlandschap. In de matig dynamische gebieden liggen kansen voor behoud en herstel van de oorspronkelijke hoofdstructuren van het agrarische cultuurlandschap. In de laagdynamische gebieden ligt de focus op behouden en waar nodig op herstellen van landschapsstructuren.

\subsection{Generieke bouwstenen}

\section{Van landschapskenmerken en opgaven naar bouwstenen}

Elk landschap heeft zijn eigen kenmerken in termen van opgaande groene landschapselementen en kavelgrootte. Naast deze meer historische kenmerken zijn er in het STEVIG-gebied door de gemeente Lochem opgaven en ambities geformuleerd voor het landschap. Deze nieuwe opgaven zijn samen met gebiedspartijen in de gemeente Lochem geïnventariseerd per landschapstype. De uitkomsten daarvan worden in de cascobenadering 'bouwstenen' genoemd: uitgangspunten en opgaven per landschapstype. Het resultaat van de analyse van de gebiedsopgaven (Hoofdstuk 3) is een set generieke bouwstenen, uitgangspunten die voor alle opgaande groene elementen binnen het STEVIGgebied gelden (tabel 5.1). Samen met kenmerken van de verschillende landschapstypen geven zij richting aan de ontwikkeling van het toekomstige landschap, doordat ze verwerkt zijn in de cascokaart. 


\subsection{Cascokaart}

\section{Gedetailleerde kaart met landschapselementen als basis}

De laatste stap in het opzetten van de cascobenadering is het maken van de zogenaamde 'cascokaart'. De basis voor deze kaart is een digitale kaart van een nulmeting, waarop alle bestaande opgaande groene landschapselementen binnen het STEVIG-gebied staan. Vervolgens zijn alle elementen uit deze nulmeting geclassificeerd naar twee typen:

- Casco-elementen: opgaande groene elementen die 'drager' zijn van het landschappelijk casco en om die reden behouden en versterkt moeten worden.

- Niet-casco-elementen: opgaande groene elementen die niet tot het casco behoren en die, volgens de spelregels van de cascobenadering, verplaatst mogen worden naar een andere plek binnen het STEVIG-gebied om zo de landbouwstructuur te verbeteren.

\section{Richting geven aan compensatie}

Tot slot is deze kaart aangevuld met lijnen die opties aangeven voor plekken waar de te verplaatsen elementen aangeplant kunnen worden (zie Hoofdstuk 5). Op deze manier wordt richting gegeven aan de wijze waarop het landschap versterkt wordt door nieuwe groene structuren zo aan te leggen. De wijze waarop de compensatie wordt uitgevoerd, is vastgelegd in de notitie 'Richtlijnen objectivering Casco Lochem' (Gemeente Lochem, 2017). 


\section{Gebiedsopgaven \& ambitie}

Om de wensen en ambities van de verschillende gebiedspartijen in beeld te brengen en te vertalen in concrete bouwstenen voor de cascobenadering, zijn verschillende interviews en bijeenkomsten gehouden. Dit hoofdstuk geeft de belangrijkste punten voor de bouwstenen weer.

\subsection{Landschap}

\subsubsection{Gemeente Lochem}

\section{Landschapsontwikkelingsplan als uitgangspunt}

Het landschapsbeleid van de gemeente Lochem is vastgelegd in het Landschapsontwikkelingsplan (Landschapsontwikkelingsvisie, 2009) van de gemeenten Bronkhorst, Lochem en Zutphen. Het LOP is door de raad in 2009 vastgesteld. Het LOP schetst een ontwikkelingsvisie, een wensbeeld per landschapstype op basis van de bestaande kwaliteiten en de huidige en toekomstige ontwikkelingen. De visie op het landschap heeft een doorvertaling gekregen in het Bestemmingsplan Buitengebied (2010). De in het LOP geschetste visie is vertrekpunt voor het project Beter boeren in een kleinschalig Landschap in de gemeente Lochem (BBKL).

\section{Landschapselementen in bestemmingsplan \& kapverordening}

Een deel van de landschapselementen is in het bestemmingsplan vastgelegd met de bestemming "bos" of valt binnen een gebied met de bestemming "natuur" (zie figuur 3.1). Deze bestemmingen zijn meegenomen als casco-element. Het merendeel van de landschapselementen is niet apart bestemd. De kap en herplant van deze landschapselementen zijn geregeld in de APV afdeling 3, artikel $4.10 \mathrm{t} / \mathrm{m}$ 4.12. Er zijn recent geen kap- of herplantaanvragen bekend bij de gemeente. De gemeente voert geen actief handhavingsbeleid op kap en herplant.

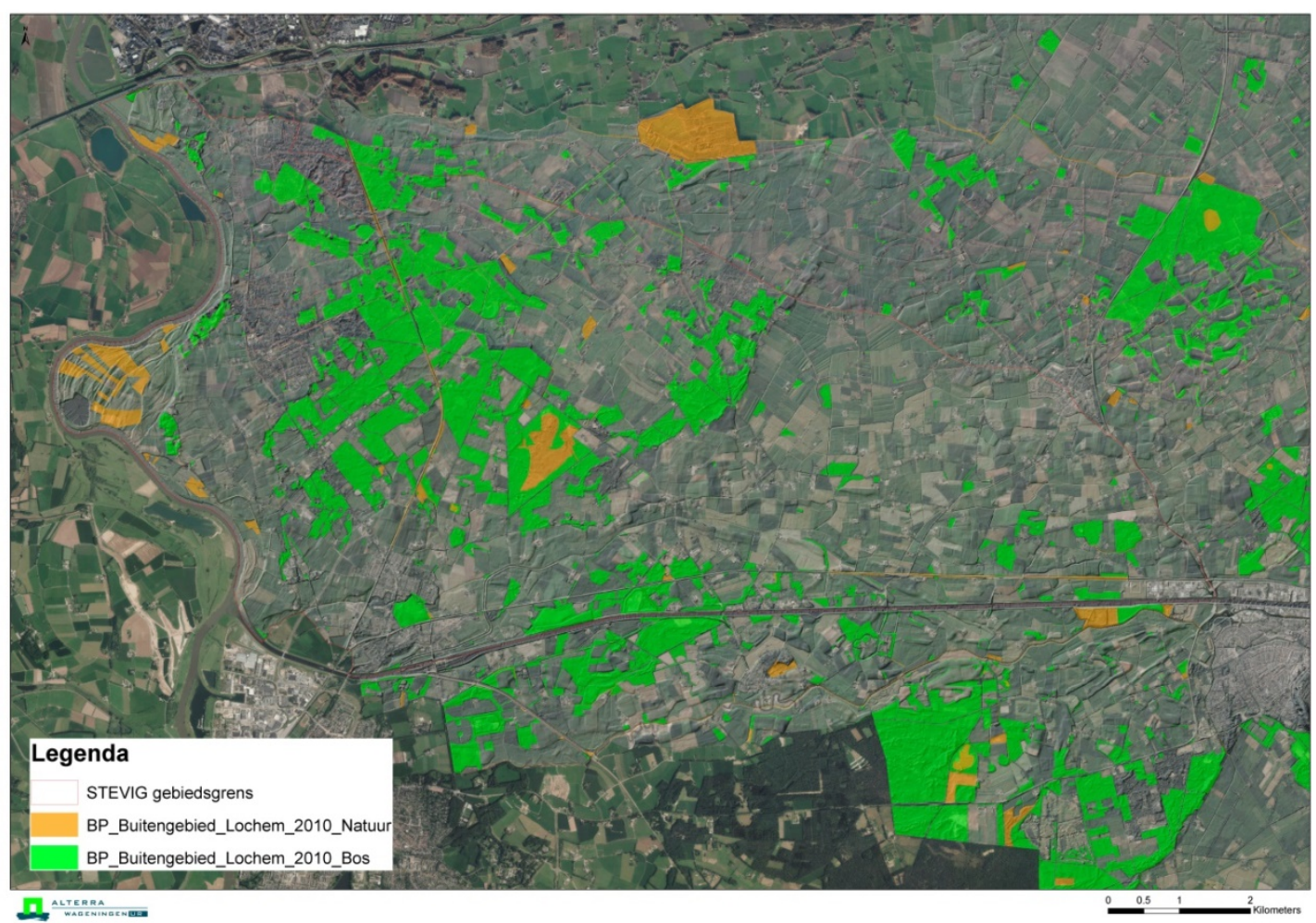

Figuur 3.1 Bestemmingen 'bos' of 'natuur' in het Bestemmingsplan buitengebied van de gemeente Lochem. 
Bij de ontwikkeling van het casco is rekening gehouden met de filosofie van de Natuurkansenkaart, een van de bijlagen bij het bestemmingsplan. De Natuurkansenkaart benadrukt de samenhang die er bestaat tussen het landschap, de bodem, het watersysteem en het natuurlijk reliëf met het voorkomen van habitats, geschikte leefgebieden voor populaties van (bijzondere) flora en fauna, die in het gebied voorkomen. De cascobenadering beoogt een duurzaam netwerk van landschapselementen te creëren, waarlangs soorten zich makkelijker kunnen verplaatsen en waardoor de overlevingskansen van populaties worden vergroot.

\section{Compenseren met kwaliteit wordt beloond}

De Gemeente Lochem staat op het standpunt dat het landschap er in het project BBKL in termen van oppervlakte landschapselementen niet op achteruit mag gaan. Dit betekent dat er wordt uitgegaan van een-op-een-compensatie bij het verwijderen van elementen ten behoeve van structuurversterking van de landbouw. Een uitzondering hierop vormt het deel van het BBKL-gebied dat binnen de grenzen van het Nationaal Landschap de Graafschap valt. Het beleid is voor dit gebied primair gericht op het behouden en versterken van de historische landschapselementen, zoals het kenmerkende waterhuishoudingsysteem, de landgoederen, en structuur van kampen en essen en het kleinschalig landschap met groene karakter. Binnen het Nationaal Landschap de Graafschap geldt daarom een compensatiefactor van $1: 1,5$.

De inzet van de gemeente is gericht op het toevoegen/verhogen van ecologische kwaliteit van bestaande en nieuw aan te leggen landschapselementen en het versterken/creëren van ecologische verbindingen voor soorten die opgaande begroeiing gebruiken voor dispersie en migratiebewegingen (Zoon buro voor ecologie, 2009). Dit betekent dat de gemeente inzet op de ontwikkeling van een netwerk van landschapselementen met soorten die bij het landschap en de groeiplaats passen en met voldoende ruimte voor de ontwikkeling van een mantel- en zoomvegetatie. Het toevoegen van kwaliteit kan beloond worden door een korting te verlenen op de oppervlakte te compenseren landschapselement (zie 5.3.1, Kwaliteitsladder).

Binnen de visie van de gemeente past ook het ontwikkelen van robuuste opgaande groene landschapsstructuur langs beken in het beekdallandschap. Deze oost-west georiënteerde elementen versterken de ecologische netwerkfunctie van het landschap. Het idee van agrarisch waterbeheer langs waterlopen (voorstel Waterschap Rijn en IJssel, zie par. 3.4) past daarmee in de visie van de gemeente.

Het verplaatsen van landschapselementen van agrarische gronden naar de randen van de percelen in de gemeentebermen is geen optie (zie ook kostenneutraal laanbomenbeheer).

Bij de beoordeling van een cascoaanvraag zal de gemeente een referentiejaar hanteren om de lengte van het landschapselement op dat moment als uitgangpunt te bepalen. Er zijn twee jaartallen geopperd om te hanteren als referentie jaar: 2005, afronding gemeentelijke herindeling van Lochem of 2010, vaststelling Bestemmingsplan buitengebied. De gemeente Lochem heeft besloten de vaststelling van het Bestemmingsplan buitengebied in 2010 als referentiejaar te hanteren. Dit betekent dat de plankaart van dit bestemmingsplan als uitgangspunt van de cascokaart is genomen.

\section{Uiterwaarden IJssel vormen aparte gebiedsopgave}

De uiterwaarden van de IJssel in de gemeente Lochem liggen binnen het STEVIG-gebied. Hier ligt een complexe gebiedsopgave. De uiterwaarden zijn vanwege hun bijzondere natuurwaarden aangewezen als N2000-gebied en grote delen daarvan vallen ook binnen de begrenzing van het Gelders NatuurNetwerk. Grote delen van deze gebieden zijn eigendom van of worden beheerd door natuurorganisaties. De landschappelijke elementen in de uiterwaarden, zoals meidoornheggen, knotwilgen en ooibossen bepalen mede de natuurkwaliteit van het gebied en vormen een belangrijk onderdeel van het landschappelijke casco.

In de uiterwaarden is tevens het Programma Stroomlijn van kracht. Stroomlijn is gericht op het in stand houden van voldoende doorstroomcapaciteit in het buitendijkse rivierengebied, zodat bij hoogwater op de rivier het water snel kan worden afgevoerd en de veiligheid wordt gewaarborgd. In het kader van Programma Stroomlijn worden in het hele rivierengebied opgaande landschapselementen afgezet of verwijderd. Ook binnen de uiterwaarden in de gemeente Lochem is dit aan de orde en daarmee van invloed op het landschappelijke casco. 
In de uiterwaarden liggen ook agrarische percelen. Deze percelen liggen verspreid in de uiterwaarden en deels tussen de natuurterreinen van het GNN. De wens vanuit de agrarische sector is om deze landbouwpercelen aaneen te sluiten ten behoeve van een efficiëntere bedrijfsvoering.

In de uiterwaarden ligt een voormalige zandwinplas. Deze plas, maar ook andere gebieden langs de rivier, wordt gebruikt voor recreatie en sportvisserij (zie figuur 3.2). Om de IJssel te bereiken worden landbouwpercelen gebruikt. Eigenenaren van de landbouwpercelen hebben aangegeven dat dit ongewenst is. Anderzijds bestaat er vanuit de bewoners van de kernen Gorssel, Epse en Eefde de behoefte dat de uiterwaarden beter toegankelijk worden voor natuurrecreatie (wandelen en fietsen).

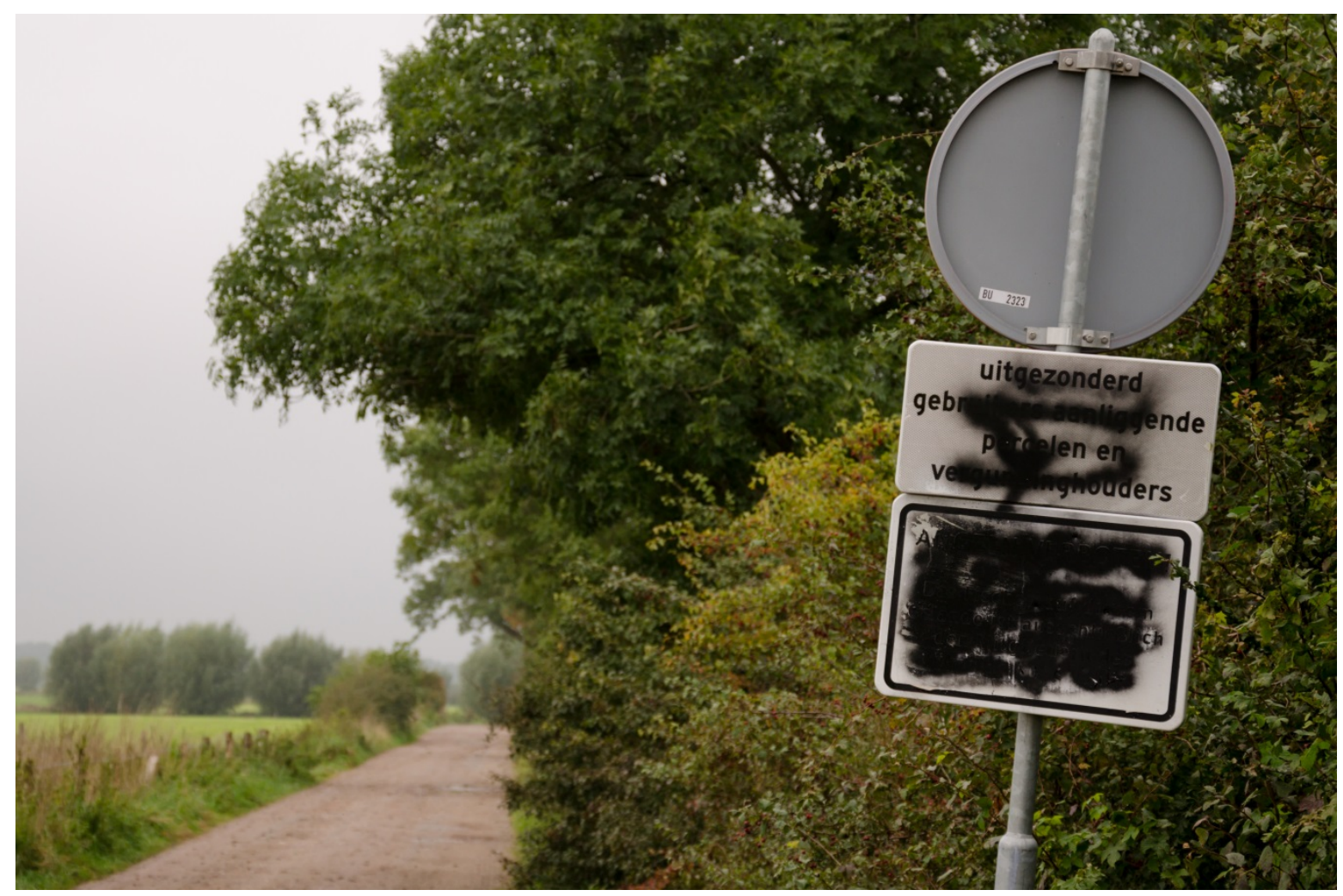

Figuur 3.2 'Uiterwaarden vrijstaat...'

- In de huidige opzet liggen alle landschapselementen in de uiterwaarden binnen het Gelders Natuurnetwerk \& Natura 2000 en maken deel uit van het landschappelijk casco.

- Tegelijkertijd is tijdens de gesprekken met gebiedspartijen gebleken dat een deel van de landschapselementen voor Rijkswaterstaat op de nominatie staat om verwijderd te worden of reeds verwijderd is, om zo de doorstroming bij hoogwater te garanderen (programma Stroomlijn). Een deel van de landschapselementen is 'vergund' en mag blijven staan. De struweelhagen haaks op de rivier leveren veel stromingsweerstand op.

- Een alternatief zou zijn om de opgaven uit programma Stroomlijn te combineren met de ontwikkeling van het casco. Dit zou kunnen door de elementen binnen het Programma Stroomlijn-gebied die dwars op de rivier staan te 'kantelen', door de bestaande elementen te verwijderen en deze elementen zo te compenseren dat ze parallel aan de loop van de IJssel komen te liggen (in hetzelfde gebied).

- Met deze aanpak kunnen meerdere gebiedsopgaven/wensen in de uiterwaarden gerealiseerd worden:

- Verbetering van de doorstroomcapaciteit, met behoud van de landschappelijke waarden;

- Verminderen van de versnippering van de huidige natuurterreinen;

- Verbetering van de landbouwstructuur (kavelruil);

- Verbeteren van de ontsluiting van de uiterwaarden voor recreatief medegebruik.

- Dit vraagt om overleg tussen gemeente, Rijkswaterstaat, STEVIG en de terreinbeherende organisaties, elk vanuit hun eigen opgave. Het cascoconcept kan hierbij leidend zijn om gezamenlijk tot nieuwe oplossingen en structuren in de uiterwaarden te komen. 


\section{Kostenneutraal laanbomenbeheer}

De gemeente is verantwoordelijk voor het beheren en waar nodig kappen van bomen langs wegen in het buitengebied, maar heeft hiervoor geen vastgesteld beleid en budget. De financiële middelen om door aanbesteding het beheer en het kappen van bomen uit te voeren, zijn beperkt. In het project Kostenneutraal laanbomenbeheer zoekt de gemeente zowel in beleid als uitvoering naar nieuwe oplossingen om het beheer en het kappen van bomen in het buitengebied zo mogelijk kostenneutraal en op een duurzame wijze vorm te geven. De gemeente doet dit in samenwerking met een brede vertegenwoordiging vanuit de samenleving (burgers, natuur en landschap, agrarische sector en recreatie).

(http://www.lochem.projectenoverzicht.nl/groep/kostenneutraal-beheer-en-onderhoud-vanlaanbomen)

In het kader van dit project wordt op dit moment de vitaliteit van alle laanbomen in beeld gebracht, met behulp van een Visual Tree Assesment (VTA) (Berkel Groen). Figuur 3.3 geeft een overzicht van alle wegen waar deze inventarisatie plaatsvindt. Geschat wordt dat er in het buitengebied langs gemeentelijke wegen ongeveer 70.000 laanbomen zijn. 20.000 daarvan zijn al in 2014 in beeld gebracht. De overige 50.000 zijn in 2015 geïnventariseerd.

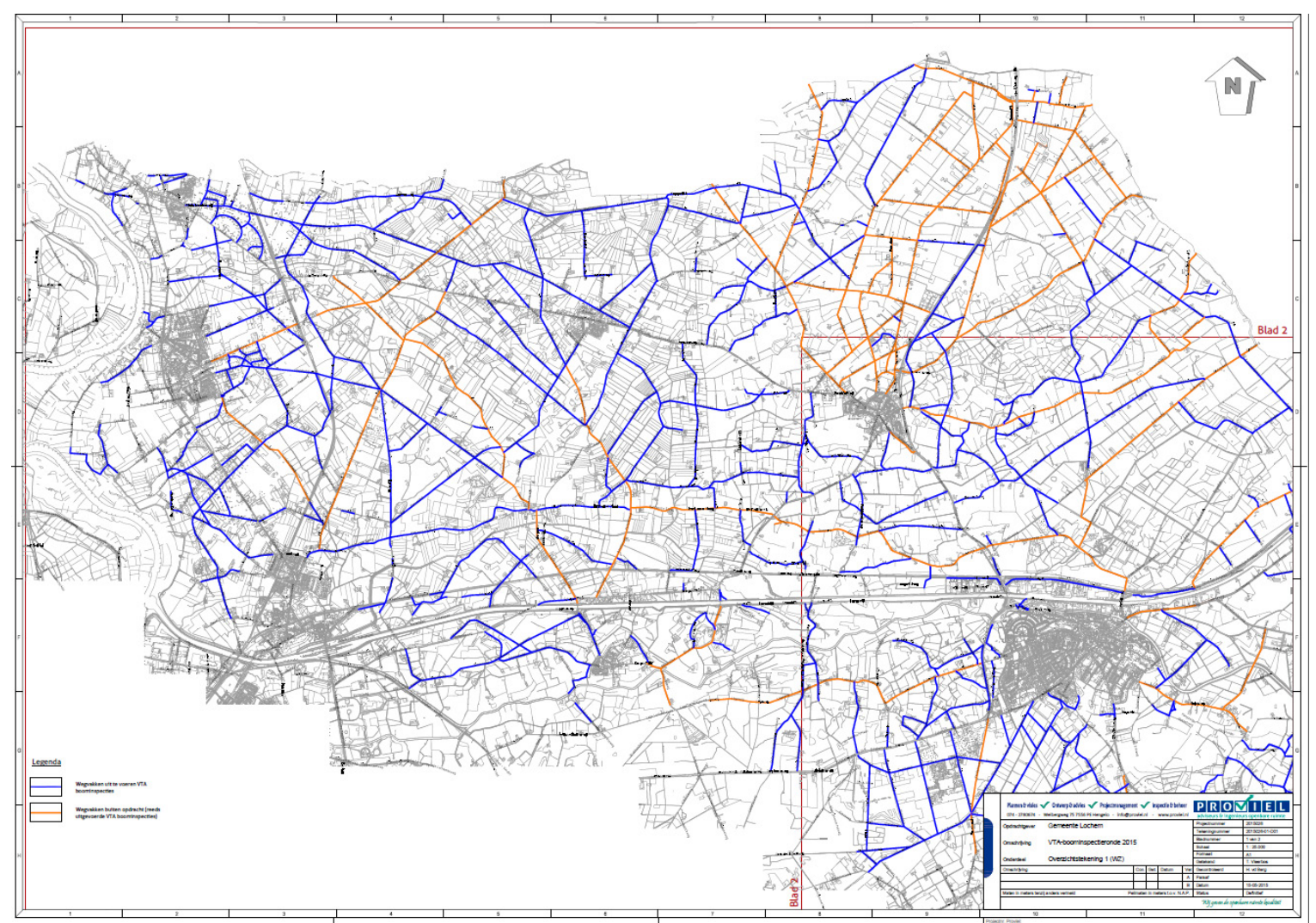

Figuur 3.3 Wegen in de gemeente Lochem waar in 2015 een VTA van laanbomen is uitgevoerd (blauw) of waar in 2014 al vitaliteitsonderzoek heeft plaatsgevonden (oranje).

Het project Kostenneutraal laanbomenbeheer neemt de landschapstypenbenadering uit het LOP als uitgangspunt voor het nieuwe laanbomenbeleid. Per landschapstype zijn kenmerken van het landschap beschreven en zijn richtlijnen geformuleerd voor kap, beheer en herplant van laanbomen naar soort en structuurtype. Tevens zijn uitgangspunten geformuleerd voor sortiment, plantafstanden en de afstand van boom tot bestaande infrastructuur. Er worden twee typen wegen onderscheiden:

- hoofdstructuren, ontsluitingswegen die de diverse landschappen doorkruisen

- secundaire wegen die binnen de landschapstypen vallen

In het kader van kostenneutraal laanbomenbeheer wordt onderzocht in hoeverre de laanbeplanting hierop bij herplant qua soort en structuur kan worden aangepast. 
De projecten BBKL en Kostenneutraal laanbomenbeheer vallen in de tijd samen. Uitgangspunt is dat de projecten elkaar kunnen versterken mits afstemming plaatsvindt. Beide projecten zijn geënt op de landschapstypen van het LOP en nemen de kenmerken van de landschapstypen als vertrekpunt. Ook compensatie/herplant is bij beide projecten aan de orde. Ook in het project Kostenneutraal laanbomenbeheer worden laanbomen die gekapt worden in principe weer herplant. Omvormen van laanbomen naar andere typen landschapselementen met een hogere ecologische kwaliteit (hakhoutsingels) wordt wel gezien als een van de mogelijkheden voor beide projecten. Hier zou synergie te bereiken zijn. Wegbermen zijn te smal om houtsingels te kunnen ontwikkelen, maar een wegbegeleidende houtsingel op grond van een particulier of agrariër wordt als een kansrijk alternatief gezien. Andersom is het niet gewenst een bestaande laanbeplanting te handhaven die concurreert met een naastgelegen houtsingel (zie figuur 3.4). Komt dit voor, dan is maatwerk een vereiste.

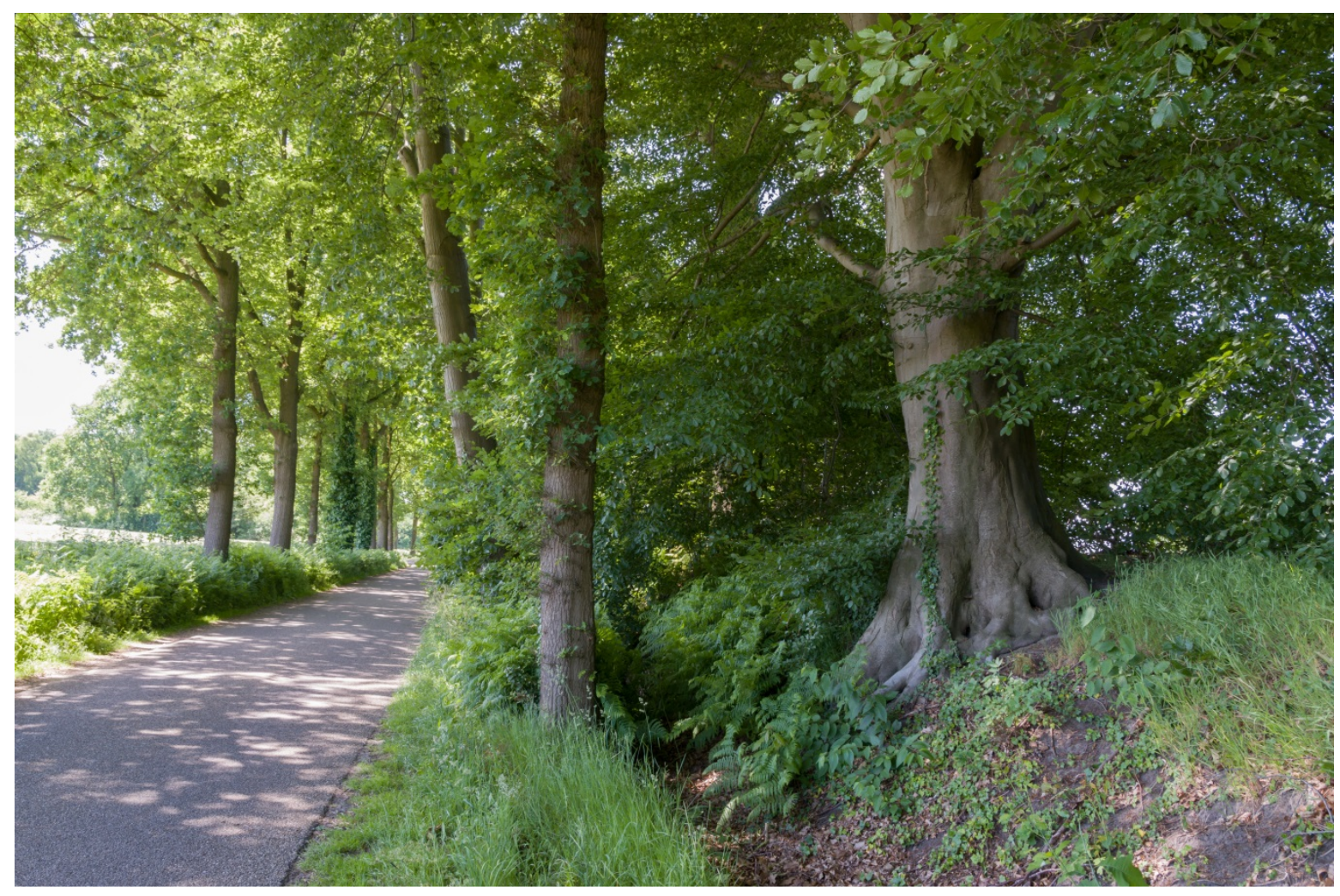

Figuur 3.4 Wegbeplanting van Amerikaanse eik (links) concurreert met houtsingel op de steilrand van een es (rechts).

BBKL biedt geen oplossing voor het oplossen van het budgetvraagstuk. Het is bijvoorbeeld niet gewenst om compensatie in BBKL te regelen via een fonds waarmee het onderhoud van laanbeplanting wordt gefinancierd. 


\subsection{Landbouw}

\subsubsection{LTO afdeling Lochem}

\section{Casco biedt mogelijkheden voor mooiere kavels}

Het kavelruilproject en de cascobenadering Lochem bieden kansen voor:

- mooiere veldkavels, structuurverbetering door verplaatsing van landschapselementen;

- ruimere toegang tot de kavels, het verbreden van doorgangen bij singels en sloten is vaak al voldoende om bewerkbaarheid te vergroten (zie figuur 3.6);

- uitruilen van landschapselementen met particulieren, bijvoorbeeld in het kader van NSW landgoederen.

LTO stelt dat een voorwaarde voor een succesvol verloop van het verkavelingsproces is dat de cascokaart met landschapselementen is vastgesteld (door de raad) voor de start van de werksessies van het STEVIG-project.

De casco-kaart wordt door LTO gezien als richtinggevend voor de mogelijkheden van verkavelen (blauwdruk). De kaart moet het ruilproces op gang brengen en op heldere wijze in beeld brengen wat de mogelijkheden zijn. Het wordt als een voordeel gezien dat je vooraf weet waar je aan toe bent.

LTO geeft aan dat er signalen zijn dat er in het gebied partijen (particulieren) zijn die landschapselementen willen ontvangen.

LTO vraagt of de cascobenadering voor de gehele gemeente geldt, zodat er elementen ook buiten het STEVIG-gebied geplaats kunnen worden. De reactie vanuit het projectteam is dat in principe de cascobenadering alleen voor het STEVIG-gebied geldig is, zodat er geen 'vlucht' van elementen uit het STEVIG-gebied naar de rest van de gemeente plaatsvindt. Wel worden de landschapstypen en de landschapselementen voor de gehele gemeente in beeld gebracht, zodat de cascobenadering (eventueel) in een later stadium voor de gehele gemeente kan gaan gelden.

De huidige praktijk is dat er nauwelijks aanvragen (kapverordening) worden gedaan voor het kappen van landschapselementen.

Agrariërs staan in principe open voor het ontwikkelen/verplaatsen van opgaande groene landschapselementen (singels en houtwallen) langs/naar watergangen mits juridisch goed geregeld.

LTO stelt de compensatiefactor van 1:1 ter discussie. Het moet mogelijk zijn om minder terug te plaatsen als de kwaliteit van het gecompenseerde element hoger is dan het verwijderde element. En als voorbeeld noemen ze het uitgangspunt dat een boer een element dat hij zelf heeft geplaatst ook weer weg moet kunnen halen. Besproken is het principe van de compensatieladder en de bonus die verkregen kan worden op kwaliteit. Besproken is dat het vertrekpunt voor alle partijen in het proces zou moeten zijn dat het landschap netto, op z'n minst, niet achteruit mag gaan. In het gesprek is niet duidelijk geworden of dit ook door de agrarische sector wordt onderschreven.

LTO onderschrijft het voorstel dat de cascobenadering niet van toepassing is op bouwblokken (en erven).

LTO onderkent de waarde van de steilranden in het gebied en geeft aan dat dit kansrijke plekken zijn om te compenseren. Het projectteam heeft bevestigd dat hiermee het landschap versterkt kan worden. Het behoud van steilranden staat niet ter discussie. Door steilranden te beplanten of door een raster te plaatsen waardoor spontaan struweel of hakhout kan ontstaan, wordt voorkomen dat deze aardkundig, ecologisch en cultuurhistorisch waardevolle elementen in het landschap langzamerhand verdwijnen.

Besproken is dat bosjes $<0,5$ ha $(\mathrm{SNL})$ nog onder de cascobenadering vallen. Grotere bossen zijn per definitie niet te verplaatsen. 


\subsubsection{ANV 't Onderholt}

\section{Collectief VALA kan beheerscontracten sluiten in STEVIG-gebied}

ANV 't Onderholt werkt samen met andere ANV's in de Achterhoek in het collectief met de naam: "coöperatieve Vereniging Agrarisch Landschap Achterhoek" (VALA). Het werkgebied van 't Onderholt omvat de gemeenten Lochem, Bronckhorst, Berkelland (alleen het deel van de voormalige gemeente Ruurlo) en het buitengebied van de gemeente Zutphen aan de oostzijde van de IJssel. Ten westen van de IJssel werkt 't Onderholt in de gemeenten Brummen en Rheden. De VALA heeft een gebiedsaanvraag bij de provincie ingediend voor agrarisch natuurbeheer in de Achterhoek. De basis voor deze gebiedsaanvraag is een voorintekening waarin grondeigenaren/pachters hebben aangegeven bepaalde pakketten met het collectief te willen afsluiten. Dit kan alleen in gebieden die door de provincie zijn aangewezen in het natuurbeheerplan. Figuur 3.5 toont het STEVIG-gebied met de plekken waar het collectief een aanbod kan doen, onderverdeeld in open grasland (weidevogels), droge dooradering, natte dooradering en natuur \& droge dooradering. De contracten worden in het nieuwe stelsel Agrarisch Natuur \& Landschapsbeheer (ANLB 2016) niet meer individueel afgesloten, maar het collectief sluit één contract met de provincie en aan de "achterdeur" sluit het collectief overeenkomsten met de grondeigenaren/pachters.

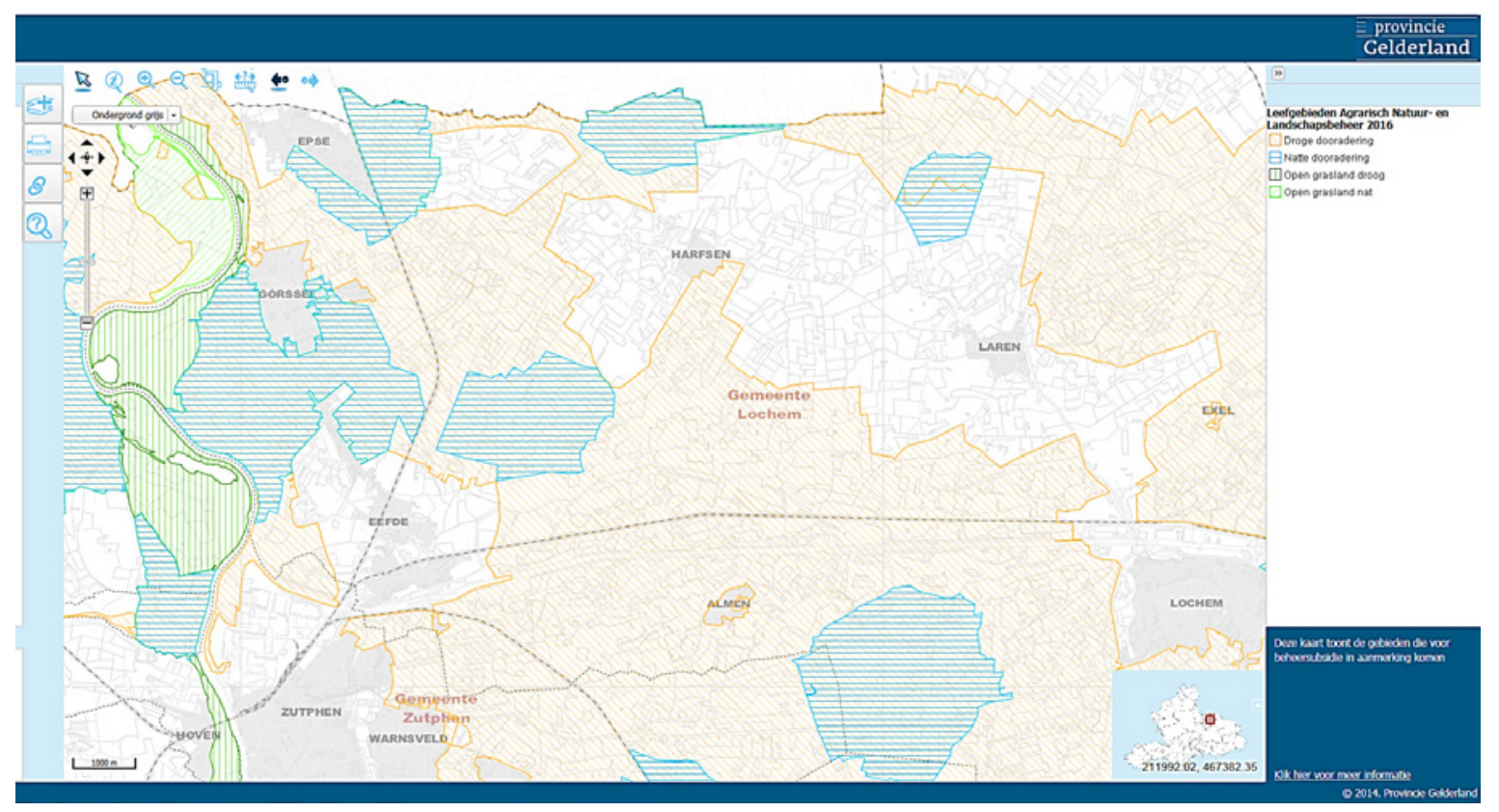

Figuur 3.5 Leefgebieden Agrarisch Natuur en Landschapsbeheer 2016 (Bron: Natuurbeheerplan: http://www.gelderland.nl/natuurbeheerplan).

\section{Vertegenwoordiging en kengetallen ANV 't Onderholt}

Agrarische natuurvereniging (ANV) het 't Onderholt heeft ruim 500 leden, zowel boeren als burgers. 't Onderholt is ook in het STEVIG-gebied vertegenwoordigd, onduidelijk is hoeveel boeren/burgers zijn aangesloten en hoeveel landschapselementen door het 't Onderholt worden beheerd.

De ANV is betrokken bij veel uitvoeringsopgaven in het gebied, zoals het beheer van elementen in uiterwaarden (programma Stroomlijn), beheer van elementen van particuliere grondeigenaren, agrariërs en het Waterschap en denkt mee in het laanbomenproject van de gemeente Lochem.

Er lopen in het STEVIG-gebied zowel oude SNL-contracten met een looptijd van max. 6 jaar als nieuwe afspraken in het kader van de gebiedsofferte. In het gebied zijn ook boeren en particulieren die op eigen initiatief en zonder subsidie landschapselementen beheren. 


\section{Coulisselandschap moet behouden blijven}

ANV benadrukt dat vanuit de landbouw zelf wordt aangegeven dat het niet nodig is om hele landschapselementen te verplaatsen. $\mathrm{Er}$ is een toenemend besef dat het coulisselandschap behouden moet blijven. Algemene mening van de landbouw is dat het hier geen 'polderlandschap' moet worden met bos aan de randen. Wel is er behoefte aan het creëren van voldoende doorgangen tussen aangrenzende percelen, zodat men niet via de openbare weg van het ene naar het andere perceel hoeft te rijden. Een generieke bouwsteen zou kunnen zijn: casco-landschapselement handhaven en voorzien van ruime doorgangen aan beide zijden van het perceel, waarbij het casco-element voldoende omvang dient te behouden.

In het kader van BBKL-Lochem is aan de vertegenwoordiging van LTO in de begeleidingscommissie gevraagd om te onderbouwen hoe breed een 'ruime' doorgang voor een goede agrarische bedrijfsvoering dan moet zijn. In figuur 3.6 wordt dit toegelicht. De werkbreedte van agrarische machines is veelal een meervoud van 3 meter. Vanuit agrarisch perspectief is een 18 meter brede doorgang de optimaalste breedte. De doorgang zelf kan dan volledig in de bedrijfsvoering worden opgenomen doordat alle bewerkingen op de aangrenzende percelen (bemesten, maaien, harken, oogsten) in dezelfde werkgang ook kunnen worden uitgevoerd in de doorgang. Voor het maken van goede verbindingen tussen percelen voldoet een breedte van 9-12 meter (zie figuur 3.7). De meeste landbouwmachines kunnen hier zonder problemen passeren.

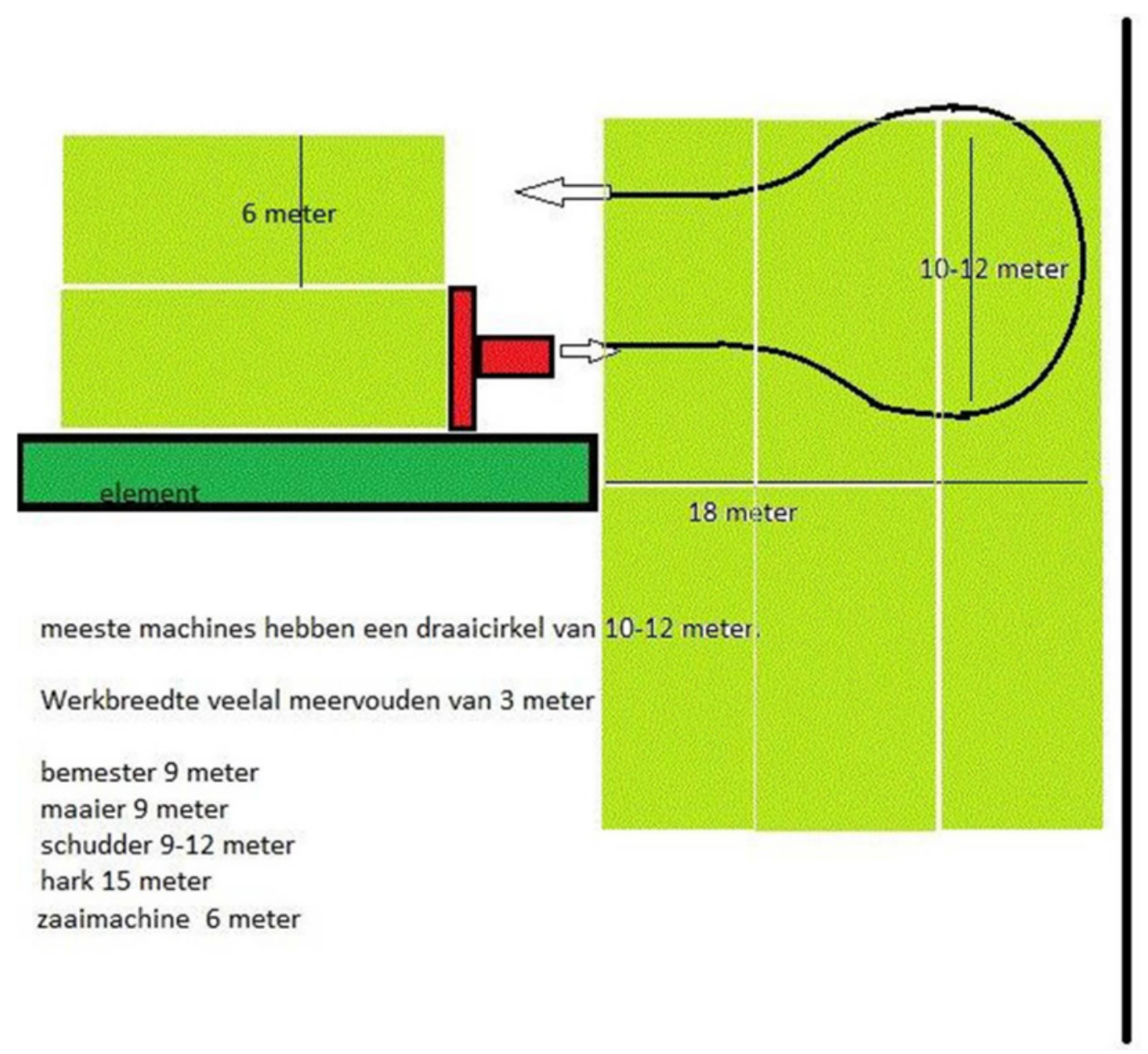

Figuur 3.6 Motivering maatvoering doorgang tussen aangrenzende percelen, gescheiden door een landschapselement om beide percelen in een werkgang te kunnen bewerken. De gewenste breedte is 18 meter, maar ook een breedte van 9-12 is voldoende voor een goede bereikbaarheid van de percelen. 


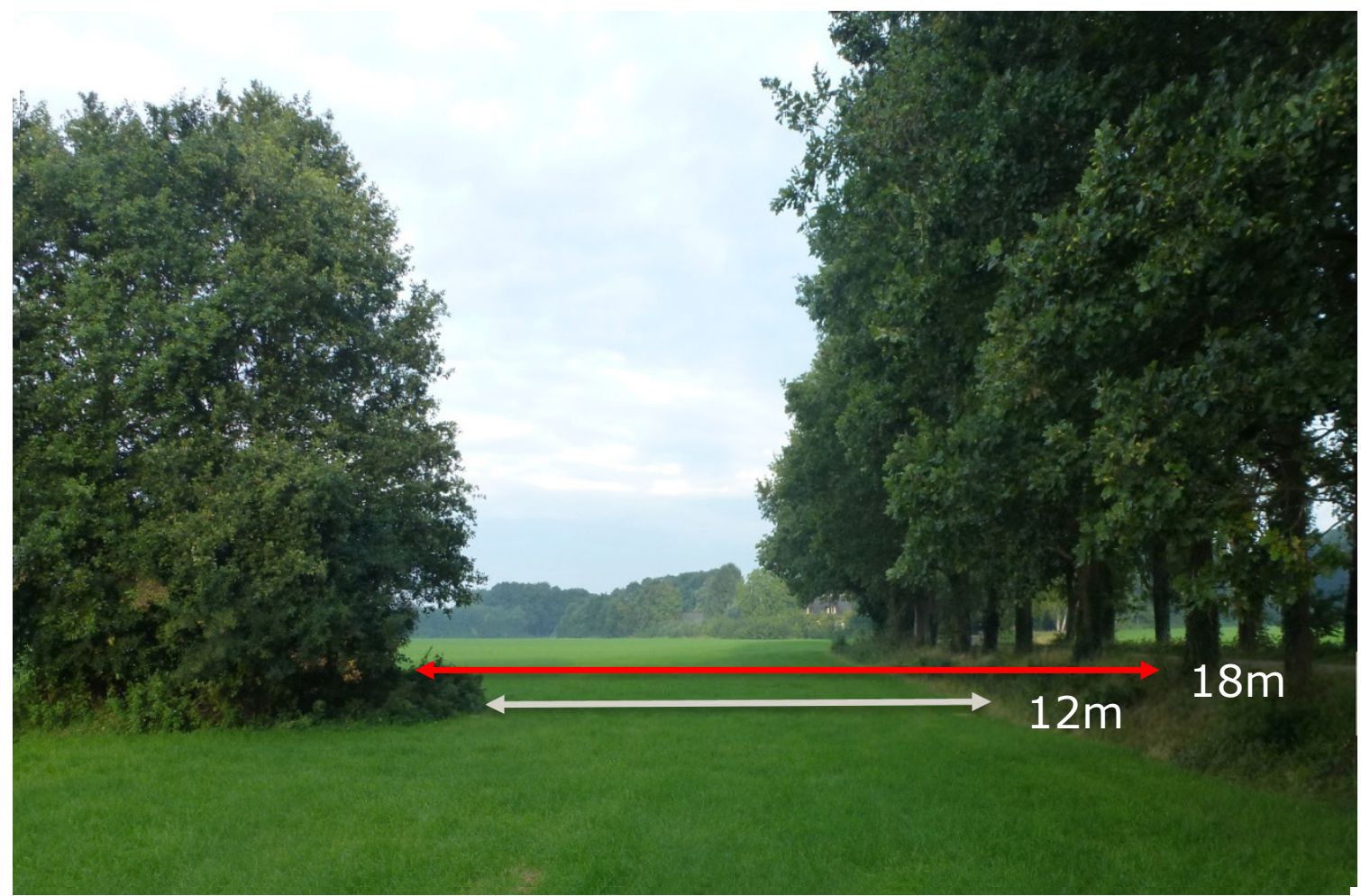

Figuur 3.7 Voorbeeld van een doorgang tussen aangrenzende percelen. De bruto-breedte is in dit voorbeeld 18 meter. De netto-breedte tussen de mantel van de houtsingel en de berm is 12 meter en is ruim voldoende voor een goede bereikbaarheid van beide percelen met modern agrarisch materieel.

\section{Herstel van het hakhoutbeheer}

Het herstellen van hakhoutsingels is zeker een van de opties voor het gebied. Opgaande eiken verwijderen en enkele overstaandens laten staan, is een belangrijke invalshoek. Ook kunnen kleine restanten van elementen, bijvoorbeeld op de steilranden, aangegrepen worden om het landschap te versterken.

De ANV is van mening dat agrarische bouwpercelen niet onder de cascobenadering moeten vallen.

Een risico voor het project is dat er in de loop van het project steeds meer bijkomt ten koste van de beschikbare grond, bijvoorbeeld een fietspad of wandelpad. Belangrijk is dat de aanspraken en belangen vooraf helder in beeld worden gebracht, zodat men niet achteraf met verrassing wordt geconfronteerd. Er is in het gebied geen behoefte aan extra paden. Door de kleinschaligheid zijn er voldoende verbindingen en op de landgoederen is voldoende wandel- en fietsgelegenheid.

De ANV heeft geen rol in het onderhoud van laanbomen in het buitengebied.

\subsection{Recreatie}

\section{Geen specifieke wensen voor recreatie}

Er liggen geen specifieke opgaven of wensen vanuit de recreatieve sector in het gebied op tafel, anders dan het op peil houden en zo mogelijk versterken van de belevingswaarde van het Achterhoekse coulisselandschap. Er is in de Achterhoek een fietsknooppuntennetwerk en er wordt gewerkt aan een knooppuntennetwerk voor wandelpaden. Het wandelpadennetwerk wordt opgebouwd uit de bestaande wandelingen (onder andere LAW's) die de Achterhoek doorkruisen. Achterhoek Toerisme coördineert dit. Door het STEVIG-gebied loopt een aantal van deze fiets- en wandelknooppuntroutes. Voor zover bekend, liggen er geen knelpunten in deze routes. Een uitgewerkt landschappelijk casco kan op den duur wel aanleiding zijn om routes te verleggen of nieuwe routes toe te voegen. 


\section{$3.4 \quad$ Water \& klimaat}

\subsubsection{Opgaven \& ambities Waterschap Rijn \& IJssel}

Het Waterschap Rijn en IJssel vraagt het landschappelijk casco zo uit te werken dat het:

- één samenhangend, ruimtelijke systeem op stroomgebiedsniveau vormt

- losse landschapselementen verbindt in een robuust netwerk

- een stelsel van opgaande beplantingen vormt dat ecologisch samenhangt met bestaande natte structuren (beken en waterlopen) en (korte vegetaties) ruige oever- en moerasvegetaties

- efficiënt is in beheer en onderhoud

Vanuit de cascobenadering worden in het plangebied een aantal watergangen aangemerkt als landschappelijk waardevol structurerend element, namelijk de Eefsebeek, Heurnerbeek, Molenbeek, Oude Eefsebeek, Dommerbeek en Flierderbeek en enkele grotere waterlopen in het Emsbroek.

Twee waterlopen zijn daarbij aangewezen als KRW-waterlichaam:

- Eefse beek

- Dommerbeek

De KRW-ambitie voor beide beken is 'laag', dat betekent dat de doelen bereikt worden door middel van (regulier) beheer en onderhoud. Ook voor niet-KRW-waterlopen is inzet van de cascobenadering mogelijk, bijvoorbeeld Oude Flierderbeek en Heurnerbeek, indien deze waterlopen vanuit de landschapsbenadering als casco-element worden voorgedragen.

Uitgangspunt voor het waterschap (WRIJ) is dat de compensatie vanuit de cascobenadering niet gebruikt mag worden om Kaderrichtlijn Water (KRW) opgaven in te vullen, daar waar (her)inrichting van het waterlichaam door het waterschap aan de orde is. Dit geldt met name voor waterlichamen met ambitieniveau 'matig' en 'hoog'. Langs KRW-waterlichamen met een lage ambitie zijn wel mogelijkheden voor de cascobenadering, omdat daar geen maatregelen van het waterschap voorzien zijn. Het aanbrengen van opgaande groene elementen kan, onder voorwaarden, door het waterschap als een plus worden gezien op de algehele waterkwaliteit en robuustheid van het betreffende watersysteem als casco-element.

Daarnaast vindt er momenteel een Nationaal Bestuursakkoord Water (NBW) toetsing in deze regio plaats, maar naar verwachting zal dit niet leiden tot grote opgaven. Wel ligt er een relatief kleine kwantitatieve opgave voor de benedenloop van de oude Fliederbeek en de Dommerbeek. De Oude Flierderbeek staat in dat kader op de lijst om de komende jaren te worden 'geherprofileeerd'. Voor de Eefsebeek geldt een beheerprobleem, deze wordt zeer frequent gemaaid, mogelijk als gevolg van een voedselrijke slib en/of waterbodem. Wellicht dat de cascobenadering hiervoor vanuit een gewenste herinrichting naar bijvoorbeeld breedspoor of beschaduwing mogelijkheden biedt.

Vanuit beheer is er een wens tot optimalisatie van het onderhoud door het omvormen van smal naar breedspoor, maar dan wel over grotere effectieve afstanden. Vanuit de cascobenadering kan hier invulling aan gegeven worden of rekening mee worden gehouden.

\section{Aanbod Agrarisch waterbeheer}

Een kansrijke ontwikkeling voor de cascobenadering is de mogelijkheid om het beheer en onderhoud van de onderhoudspaden onder agrarisch waterbeheer te brengen, als onderdeel binnen het Agrarisch natuurbeheer. Door het waterschap is hiervoor in samenspraak met de VALA en provincie een model uitgewerkt. Door toepassing van dit model ontstaan er mogelijkheden om aan één zijde langs de watergang en gedeeltelijk op het hier veelal aanwezige onderhoudspad opgaande groene landschapselementen te compenseren. Bij voorkeur vindt dit plaats op de zuidoever in verband met de schaduwwerking op de beek. De andere zijde van de watergang dient daarbij dan een $4 \mathrm{~m}$ brede strook voor het beheer van de watergang te verkrijgen (niet per se in eigendom van het Waterschap). Hierop kan een agrarisch waterbeheerovereenkomst op worden afgesloten. Dit zou ook van toepassing kunnen zijn voor de hierboven genoemde watergangen binnen het STEVIG-gebied. 
Het waterschap beoogt met agrarisch waterbeheer de volgende doelen en/of gebiedsvoordelen te bereiken:

- Verbetering waterkwaliteit door bufferstroken

- Optimalisering bedrijfsvoering onderhoud en verlagen onderhoudskosten

- Vergroten van waterberging in het systeem door aanleg van schuine bosoevers

- Vergroting beleving waterlopen en verbetering biodiversiteit

- Benutten maaisel voor het verhogen van het organische stofgehalte in de bodem t.b.v. een betere nutriënten- en vochtbalans

- Vergroting draagvlak en verdienmodel agrariër

- Efficiënte inzet en benutting grondgebruik

- Gebiedscoalities en denken vanuit de 'Watervisie'

Voor het overeenkomen van agrarisch waterbeheer gelden de volgende vooraarden:

Voorwaarden vanuit het waterschap:

- Alleen langs waterlopen opgenomen in de kaart agrarisch waterbeheer als onderdeel van het agrarisch natuurbeheer

- Minimaal aaneengesloten trajecten van brug tot brug

- Implementeren in grote aaneengesloten gebieden, opstarten in deelgebieden is mogelijk

- Acceptatie en verwerking maaisel op bouwland in de nabije omgeving

- Onderhoudspaden dienen voorafgaand aan de te maaien watergang gemaaid te zijn

- Het onderhoud van de houtsingels ligt bij derden

- Er geldt een ontvangstplicht voor maaisel

Voorwaarden vanuit Agrarisch waterbeheer als onderdeel uit het Natuurbeheerplan:

- Spuit- en mestvrije zones, afvoeren bagger/maaisel uit watergangen

- Beheervoorwaarden (extensief hooiland): maaien en afvoeren en/of begrazen, minimaal 4 doelsoorten uit de vegetatielijst

De ontwikkeling van opgaande beplanting langs waterlopen in combinatie met een agrarisch waterbeheer leidt tot robuuste watersystemen, die een wezenlijke bijdrage leveren aan het landschappelijk cascoraamwerk. Naast agrarisch waterbeheer op de onderhoudsstrook geldt ook de mogelijkheid van een reguliere bruikleenovereenkomst. Hierbij wordt over en weer tussen waterschap en grondeigenaar een overeenkomst onder voorwaarden afgesloten voor het gebruik van het onderhoudspad.

\section{Cascobenadering bij waterlopen}

De cascobenadering langs hiervoor aangewezen waterlopen is hieronder nader uitgewerkt. Het principe werkt als volgt: opgaande groene landschapselementen die niet tot het landschappelijk casco behoren, kunnen op de zuidoever van daartoe aangewezen beken en watergangen worden gecompenseerd (voor een schematische uitwerking zie figuur 3.8). Figuur 3.9 laat een watergang zien met aan weerzijden van de beek een onderhoudspad dat kan worden omgezet naar een situatie met een eenzijdig onderhoudspad van 4 meter en een beekbegeleidende (elzen)singel op de zuidoever van de watergang (figuur 3.10).

Het bestaande onderhoudspad wordt aan een zijde van de watergang verbreed tot een 4 meter brede strook. Het bestaande onderhoudspad blijft eigendom van het waterschap, maar wordt in bruikleen uitgegeven onder voorwaarden van mest- en spuitvrij beheer. Op de noodzakelijke aanvullende meters voor het verkrijgen van een 4 meter brede strook voor onderhoud met breedspoormaterieel wordt door het waterschap een zakelijk recht gevestigd. Aanvullend kan op deze 4 meter strook een agrarisch waterbeheerovereenkomst worden afgesloten, waarbij als voorwaarde geldt dat maaisel wordt afgevoerd en het pad als extensief hooiland wordt beheerd (mest/spuitvrij, 1 à 2 x maaien en afvoeren, behalen 4 doelsoorten).

Aan de andere zijde (bij voorkeur de zuidzijde) van de waterloop wordt het bestaande onderhoudspad ( 1.80 of $3 \mathrm{~m}$ ) omgezet in een casco-beplantingselement. Het nieuw aan te leggen casco-element is breder dan het oorspronkelijke onderhoudspad; de minimale breedte van het compensatie-element is 3-5 m, dit is inclusief het onderhoudspad. Het totale element komt in beheer en ook in eigendom van de boer. Het is mogelijk hierop een landschapssubsidie af te sluiten in het kader van agrarisch natuur \& landschapsbeheer. 
Brede watergangen (Dommerbeek en Eefsebeek o.a. KRW waterlichamen)

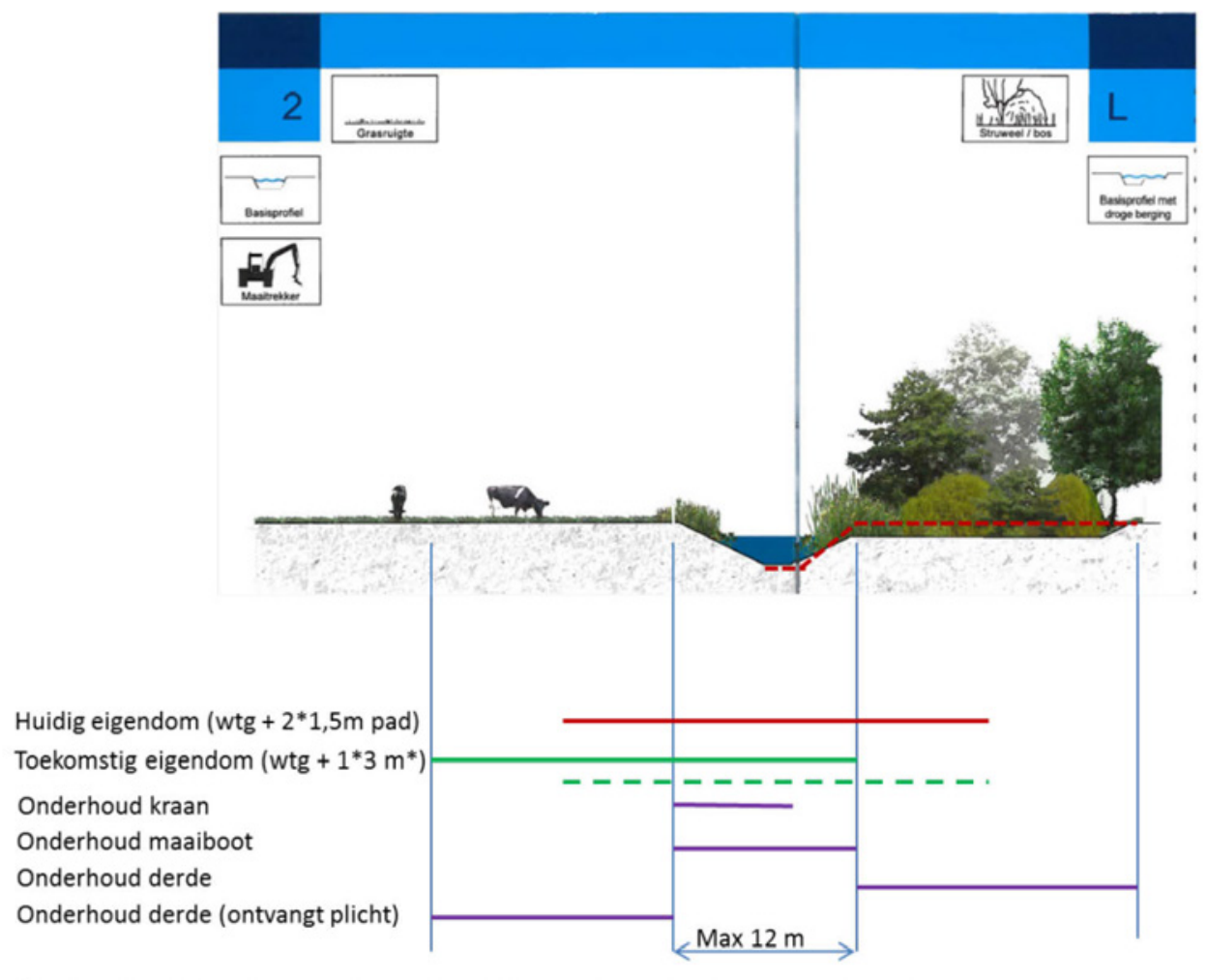

* Voorkeur WRIJ is $4 \mathrm{~m}$ breed breedspoor pad in eigendom, in dit geval is de 2×1,50m aan één kant gelegd.

Figuur 3.8 Het voorstel van het Waterschap Rijn \& IJssel voor aanleg van beplanting langs watergangen.

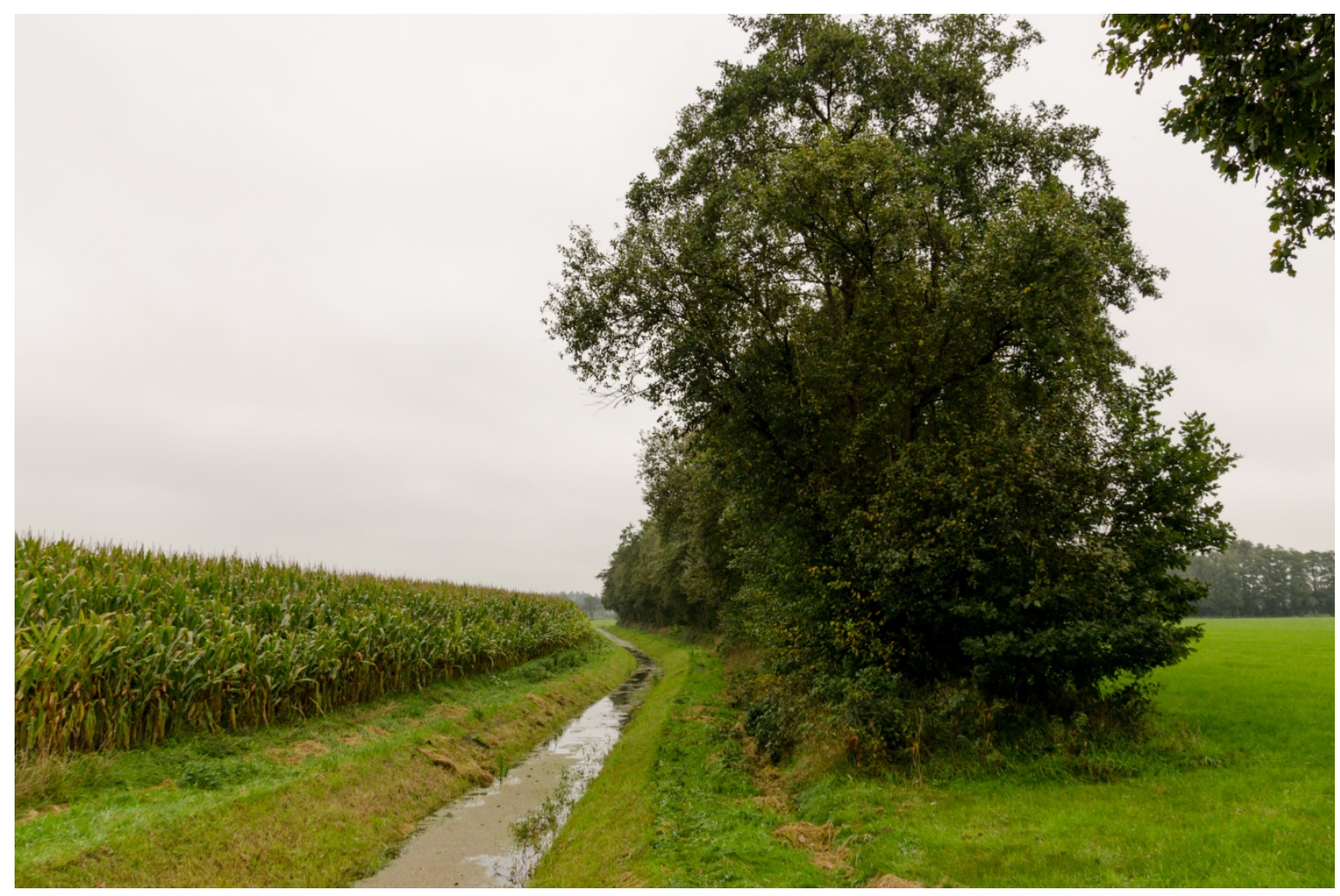

Figuur 3.9 Houtsingel langs een watergang in het Emsbroek met aan weerzijden een onderhoudspad van $1.80 \mathrm{~m}$. 


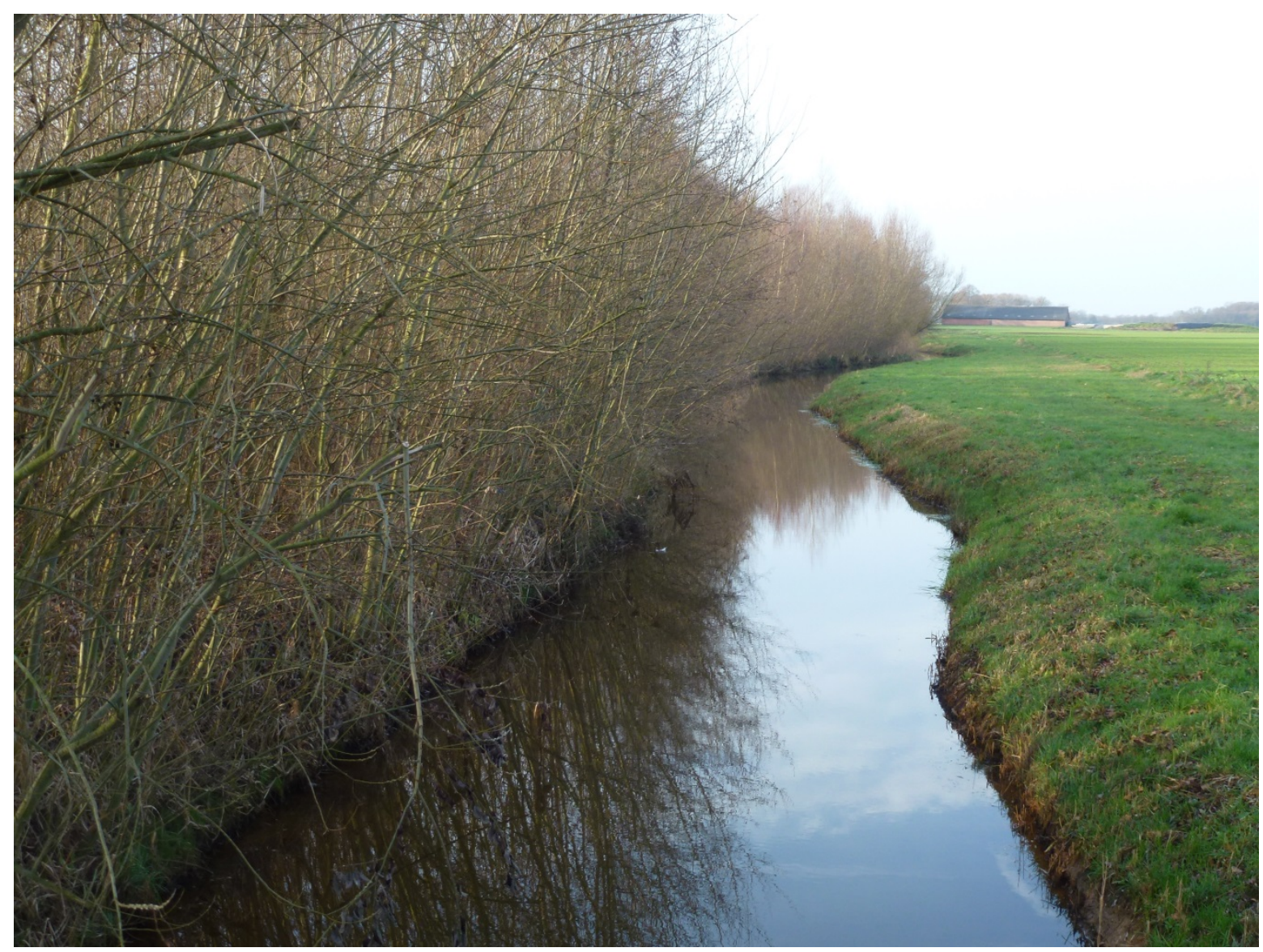

Figuur 3.10 Voorbeeld van een situatie in het beheergebied van het Waterschap Rijn en IJssel van een beekbegeleidende elzensingel op de zuidoever van een watergang met een 'eenzijdig' onderhoudspad van circa 4 meter.

\section{Grondverrekening en rechten}

WRIJ stelt voor de betreffende casco-waterlopen haar gronden aan beide zijden van de waterloop beschikbaar. Deze zijn als hooiland/houtsingel/struweel te gebruiken en komen voor agrarisch waterbeheer of een bruikleenovereenkomst in aanmerking. WRIJ streeft in beginsel naar een gesloten grondverrekening waarbij het eigendom van de ondergrond van een te vormen casco-element wordt verruild naar de overzijde van de waterloop ten behoeve van een 4 meter brede strook, geschikt voor breedspoormaterieel. Als verruiling niet lukt, kan het pad verkocht worden. De vastlegging geschiedt via bruikleenovereenkomsten en zakelijk recht. Daarnaast zijn er wellicht mogelijkheden van betalingsrechten en GLB-vergroening. De landbouw levert bij agrarisch waterbeheer aanvullend een strook landbouwgrond in. Het totaal wordt omgezet naar een agrarisch waterbeheerovereenkomst en daarmee komt de totale strook naar verwachting in aanmerking voor betalingsrechten bij gebruik als extensief grasland. Toetsing vanuit RVO blijft geboden.

Voor de mestboekhouding mag alle grond worden meegeteld die in de gewaspercelenregistratie als landbouwgrond staat geregistreerd. Op een perceel dat onder SNL-agrarisch valt, mag volgens de pakketvoorwaarden geen mest worden gebracht. Deze gronden die als botanisch grasland beheerd worden, kunnen wel worden meegenomen in de mestplaatsingsruimte. Alles onder goedkeuring van RVO. 


\section{$4 \quad$ Karakterisering landschapstypen}

\section{$4.1 \quad$ Inleiding}

In dit hoofdstuk gaan we in op de agrarische cultuurlandschappen in het STEVIG-gebied binnen de gemeente Lochem. Door te beschrijven wat de belangrijkste kenmerken van elk historisch landschapstype zijn en hoe deze herkend kunnen worden op oude kaartbeelden en wellicht ook nu in het veld of op luchtfoto's, dragen we bij aan een basis en landschappelijk referentiekader voor het STEVIG-project als geheel en voor de analyse van de landschappelijke dynamiek in het bijzonder.

Het landschap is het resultaat van een wisselwerking tussen natuurlijke en menselijke landschapsvormende factoren. Mensen richten een landschap in en ze moeten daarbij rekening houden met de mogelijkheden die het landschap biedt. Landschappen veranderen door natuurlijke ontwikkelingen, maar vooral onder invloed van maatschappelijke (politiek-economisch-technische) veranderingen. Niet alleen in de vorige eeuw hebben de Nederlandse landschappen een sterke gedaanteverwisseling ondergaan, ook in de eeuwen daarvoor kwamen landschapstransformaties periodiek voor, als antwoord op veranderende economische, politieke of technische situaties en mogelijkheden. Met andere woorden: ook het landschap van 1900, van 1800 of van 1700 heeft vele voorgangers gehad.

Het STEVIG-project gebruikt als historisch referentiekader het landschap van omstreeks 1900. Waarom 1900? Enerzijds was het STEVIG-gebied toen al voor het grootste deel ontgonnen, zodat we vrijwel vlakdekkend kunnen terugvallen op een agrarisch referentie-cultuurlandschap. Anderzijds was dat agrarische cultuurlandschap nog niet sterk veranderd door ruilverkavelingen en schaalvergroting. Dankzij de zogenoemde Bonnekaart (officieel Chromotopografische Kaart des Rijks) weten we tot in detail hoe het landschap er rond 1900 uitzag.

Per historisch landschapstype (zie figuur 4.3) worden de volgende kenmerken met bijbehorende bronnen beschreven:

- Kenmerken:

- ruimtelijke situering, hoogteligging en reliëf

- bodemtypen volgens de Bodemkaart van Nederland 1:50.000 (De Vries et al. 2003), zie figuur 4.1

- grondwatersituatie volgens de Bodemkaart van Nederland 1:50.000, grondwatertrappen (De Vries et al. 2003), zie figuur 4.2

- verkavelingsstructuur en historisch landgebruik (Bonnekaart ca. 1900)

- karakteristieke landschapselementen

- evt. kenmerkende veld- of plaatsnamen

- Kenmerken van de grens met andere historische landschapstypen

- Overige bijzonderheden: bijv. Natura 2000 en project Stroomlijn (RWS) in Uiterwaarden/IJsselterraslandschap

We illustreren dit zo veel mogelijk met kaarten en foto's. 


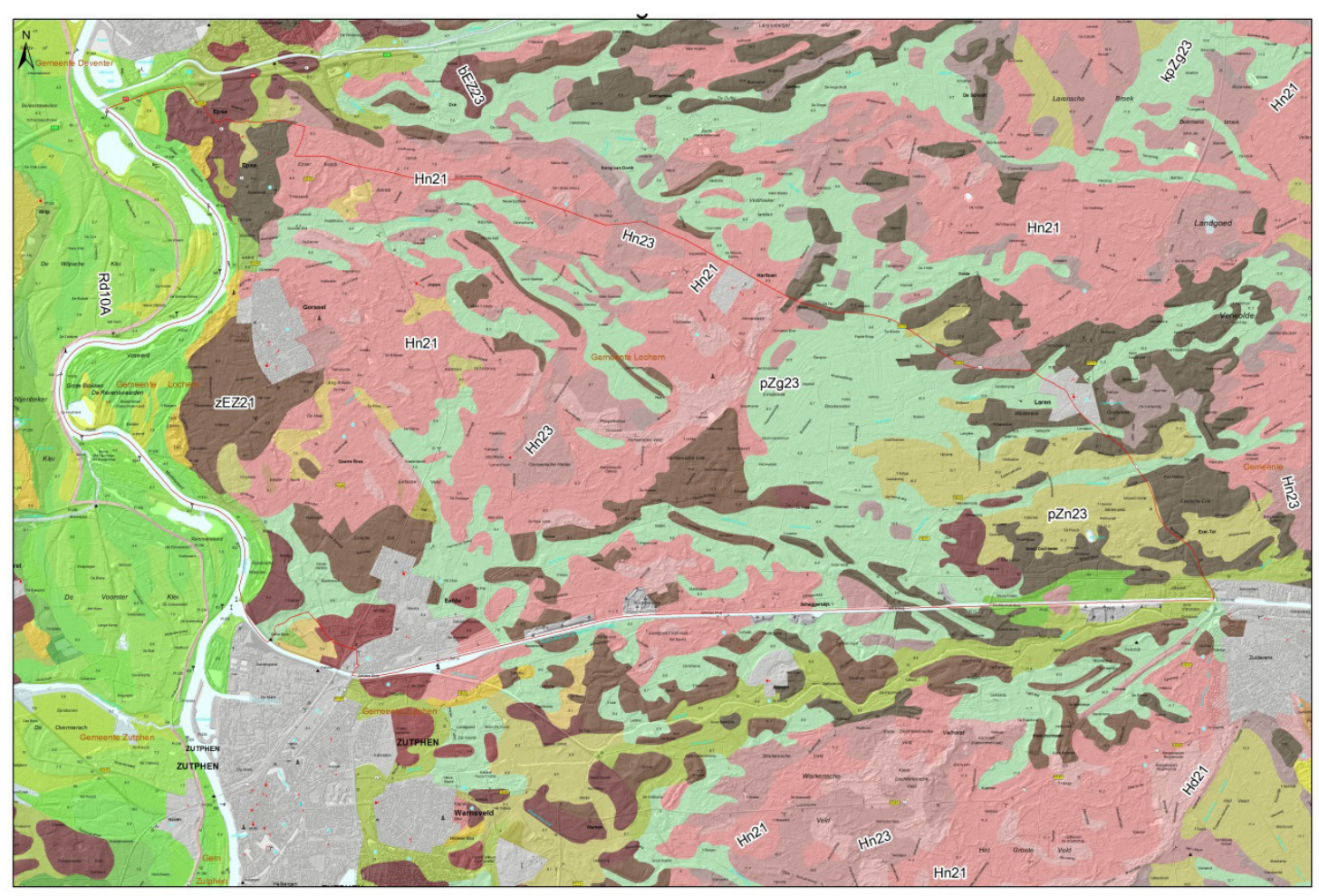

D. ALtERRA

Figuur 4.1 Bodemtypen volgens de Bodemkaart van Nederland 1:50.000 (De Vries et al. 2003). De rode lijn geeft de grens aan van het STEVIG-gebied.

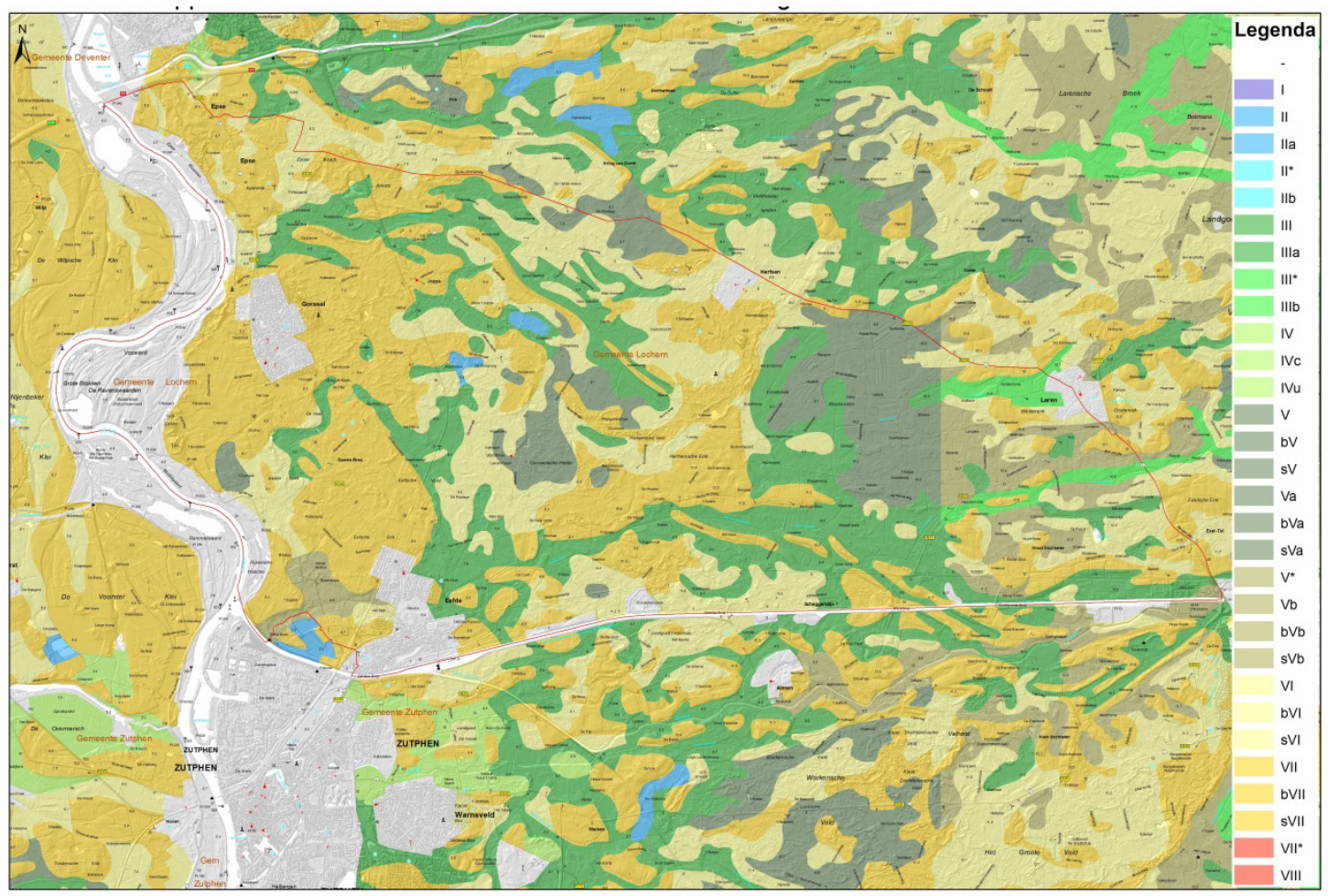

D.

Figuur 4.2 Grondwatertrappenkaart van Nederland (De Vries et al. 2003). De rode lijn geeft de grens aan van het STEVIG-gebied. 


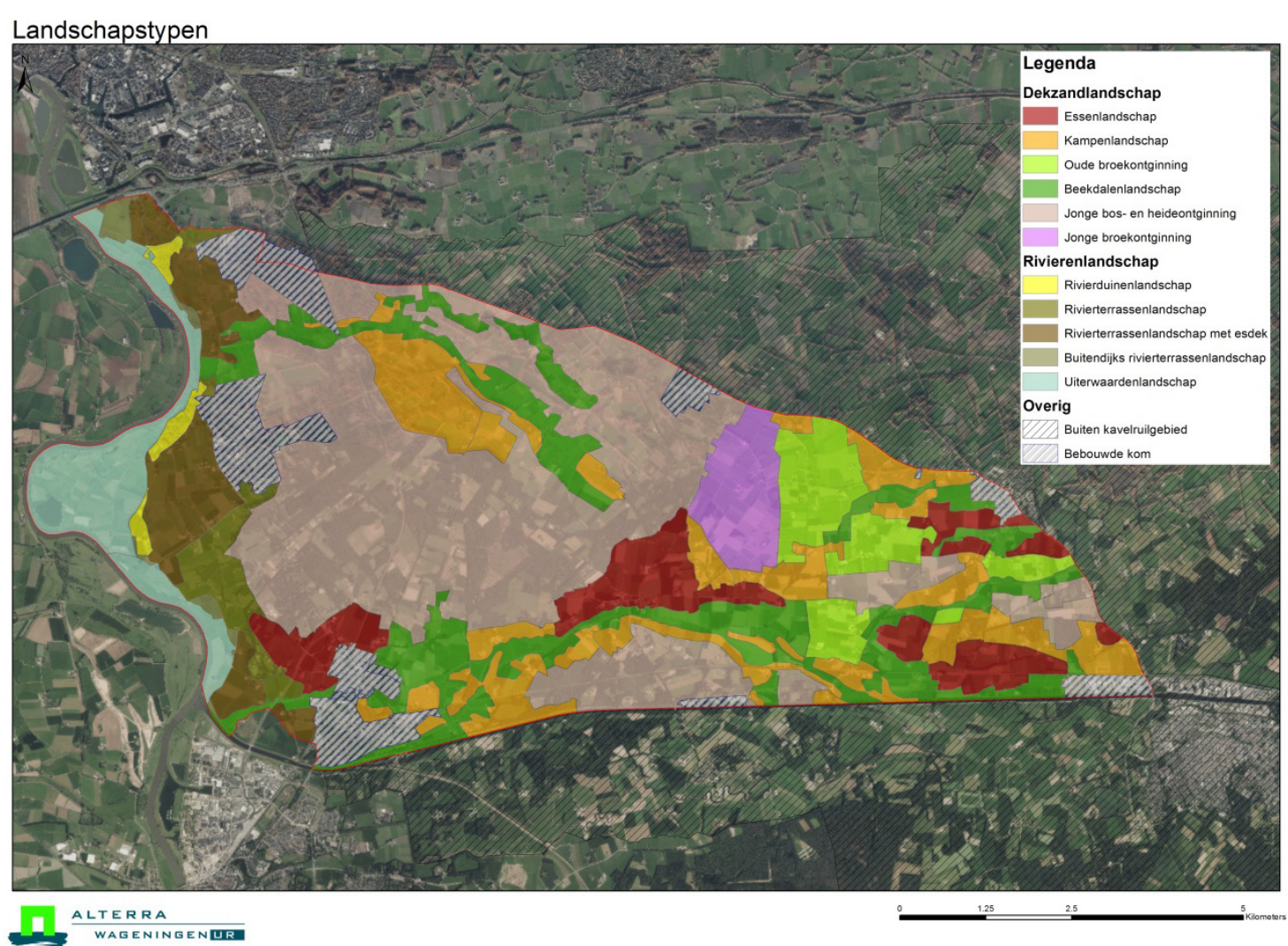

Figuur 4.3 Overzicht van de onderscheiden historische landschapstypen. Achtergrond: actuele luchtfoto 2014 (PDOK).

\subsection{Indeling landschapstypen}

Op grond van de geologische ontstaansgeschiedenis delen we het STEVIG-gebied in twee hoofdlandschappen:

- rivierenlandschap

- dekzandlandschap

Binnen deze hoofdlandschappen onderscheiden we vervolgens de verschillende landschapstypen die het gevolg zijn van de wisselwerking tussen natuurlijke en menselijke landschapsvormende factoren. Deze landschapstypen vormen het uitgangspunt voor de cascobenadering.

\subsection{Landschapstypen rivierengebied}

Binnen het rivieren landschap onderscheiden we vijf verschillende landschapstypen (zie figuur 4.3):

- Uiterwaardenlandschap

- Rivierterrassenlandschap (buitendijks)

- Rivierduinenlandschap

- Rivierterrassenlandschap (binnendijks)

- Rivierterrassenlandschap met esdek

Het rivierenlandschap begint, zoals men zou verwachten, niet bij de winterdijk van de IJssel, maar ook het binnendijkse landschap ten westen van de lijn Eefde-Gorssel-Epse is van oorsprong door een rivier gevormd. Dit deel van het rivierenlandschap onderscheidt zich van de buitendijkse uiterwaarden doordat het wat hoger ligt en de kenmerken heeft van een rivierterras. Dit komt tot uiting in onder andere het reliëf, de bodem, het landgebruik en de (planten)soorten die er van nature voorkomen. De rivierduinen markeren de randen van dit terras. Doordat de IJsseldijk niet overal de rand van het 
terras volgt, zijn delen van het rivierterrassenlandschap na aanleg van de winterdijk buitendijks komen te liggen. We behandelen de verschillende landschappen in volgorde van hun ligging ten opzichte van de rivier: de uiterwaarden eerst en het rivierterras met esdek als laatst.

\subsubsection{Uiterwarden}

\section{Ruimtelijke situering, hoogteligging en reliëf}

Het Uiterwaardenlandschap vormt het laagstgelegen deel van het projectgebied en bevindt zich buitendijks, in het winterbed van de IJssel (figuur 4.4). Het reliëf wordt in dit landschapstype gevormd door de afwisseling van meanderruggen, -geulen en oeverwallen.

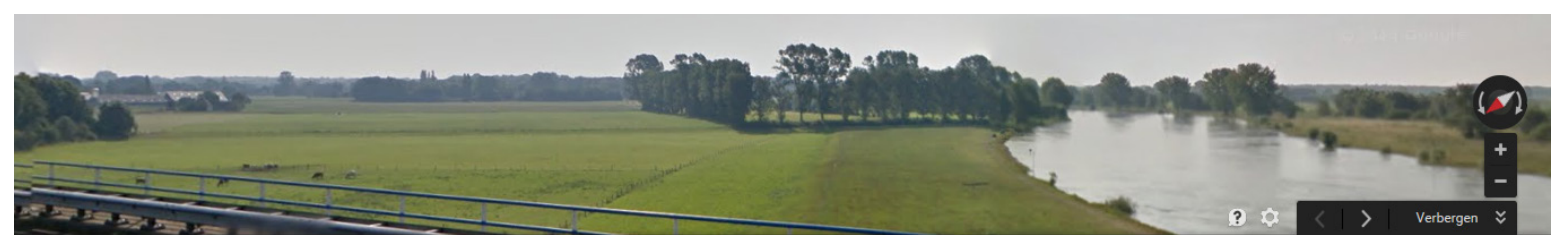

Figuur 4.4 Zicht vanaf de A1 op de uiterwaarden van de IJssel in het noorden van het projectgebied. Bron: Google Streetview.

\section{Bodemopbouw en grondwatertap}

In het Uiterwaardenlandschap in het projectgebied vinden we overwegend kalkhoudende ooivaaggronden ( $R d 90 A, R d 10 A$ ) en poldervaaggronden (Rn95A), bestaande uit lichte of zware zavel of lichte klei. Ook komen er lokaal wat hoger gelegen zandiger afzettingen voor (oeverwallen) die gerekend worden tot de kalkhoudende vorstvaaggronden (Zb20A). De kalkloze ooivaaggronden in de uiterwaarden bestaande uit lichte zavel ( $\mathrm{Rd} 10 \mathrm{C})$ behoren tot het buitendijkse rivierterassenlandschap. In de uiterwaarden zijn geen grondwatertrappen onderscheiden, omdat de grondwaterstand hier sterk beïnvloed wordt door de fluctuatie van de waterstand van de IJssel.

\section{Verkavelingsstructuur en historisch landgebruik}

Onregelmatige blokverkaveling, plaatselijk onregelmatige strokenverkaveling (Ravenswaard). Historische landgebruik bestond voornamelijk uit grasland. Op de hogere delen (bijv. fijnzandige kalkhoudende vorstvaaggronden) ook bouwlandpercelen. Perceelgrootte variabel: van minder dan 1 ha tot ca. 6 ha.

\section{Mate van openheid en karakteristieke landschapselementen}

Relatief open. Her en der bomenrijen en struweel, soms lijnvormig. Aan oevers IJssel lijkt sprake van zachthoutooibos (wilgen?). Ook (lijnvormige) moerassige zones, oude watervoerende nevengeulen/strangen en plasjes, soms onderdeel van een gegraven afwateringssysteem.

Actueel: relatie van opgaande landschapselementen met Natura 2000 en project Stroomlijn (RWS).

\section{Kenmerkende veld- of plaatsnamen}

Diverse veldnamen met 'waard'. Gorsselsche Schoor (schoor = (hoge) oever?; vgl. Engelse shore).

\section{Kenmerken van de grens met andere landschapstypen}

Overgang naar ouder rivierterras.

\section{Relatie met landschapstypenindeling uit LOP}

LOP 'Uiterwaarden, kronkelwaarden, komgronden'. Onderscheid met ouder rivierterras in LOP dat deels buiten de huidige winterdijken doorloopt, wordt in LOP niet gemaakt. 


\subsubsection{Rivierduinen}

\section{Ruimtelijke situering, hoogteligging en reliëf}

In het projectgebied vinden we op een aantal plaatsen in het IJsseldal rivierduinen. Ze zijn ontstaan door opstuiving van zand uit het rivierdal en liggen steeds op de rand van het oudere rivierterras, waar dit grenst aan het lager gelegen Uiterwaardenlandschap. De rivierduinen hebben een uitgesproken en vrij grillig reliëf.

\section{Bodemopbouw en grondwatertrap}

Het karakteristieke bodemtype van de rivierduinen in het projectgebied behoort tot de vorstvaaggronden met leemarm en zwak lemig fijn zand (Zb21). Het zand van de rivierduinen is ontkalkt. Het begrip vaaggrond duidt op bodems waarin bodemvorming nog maar in geringe mate heeft plaatsgevonden en waarin bijgevolg nauwelijks of geen sprake is van de vorming van horizonten. Vaaggronden zijn over het algemeen humusarm. Rivierduinen hebben een grondwatertrap VII (GT VII* en VIII werden in de periode dat dit kaartblad werd gekarteerd nog niet onderscheiden).

\section{Verkavelingsstructuur en historisch landgebruik}

De rivierduinen in het projectgebied vertonen op de Bonnekaart ca. 1900 een onregelmatige blokverkaveling en zijn grotendeels bebost, vooral met loofhout, maar lokaal ook met naaldhout. Waarschijnlijk gaat het om actieve beplanting met als doel zandverstuiving naar aangrenzende landbouwgronden tegen te gaan. Meer dan agrarische kavels gaat het in veel gevallen om boskavels. De kavelafmetingen zijn vergelijkbaar met die in het historische Kampenlandschap (van minder dan 0,5 ha tot ca. 8 ha). Plaatselijk zijn de rivierduinen begroeid met heide. Het areaal rivierduin dat in gebruik is als bouwland of grasland is klein; we vinden dit plaatselijk aan de randen en uitlopers.

\section{Mate van openheid en karakteristieke landschapselementen}

De rivierduinen in het projectgebied vormen een klein historisch landschapstype met een gesloten karakter door de hoge bebossingsgraad en het sterke reliëf. Gegeven hun geringe omvang (ca. 15-30 ha per duinlichaam) kunnen we de rivierduinen zelf als landschapselementen in de grotere ruimtelijke eenheid van het IJsseldal beschouwen. Afgezien van de grotere (loof)bossen op de rivierduinen zijn er kleine bosstrookjes als uitloper of voortzetting hiervan en lokaal bomenrijen.

\section{Kenmerkende veld- of plaatsnamen}

Namen met belt (heuvel-veldnaam) en met loo (bos-veldnaam) zoals de veldnaam Eesterloo en de boerderijnamen 't Loo, Boschloo en 'De Beltman'. De loo-veldnamen suggereren dat de bebossing van de rivierduinen mogelijk al eeuwenoud is.

\section{Kenmerken van de grens met andere landschapstypen}

Door het uitgesproken reliëf van de rivierduinen en het feit dat de arme en droge zandgronden waaruit ze bestaan grotendeels bebost zijn, steken de rivierduinen duidelijk af tegen de omringende historische landschapstypen. Op de overgang naar het Uiterwaardenlandschap komt daar de steilrand tussen ouder rivierterras en lagere uiterwaard bij.

\section{Relatie met landschapstypenindeling uit LOP}

Het LOP onderscheidt de rivierduinen niet als afzonderlijk landschapstype. Ze lijken in het LOP onderdeel te zijn van het 'Enken/essenlandschap' (in onze indeling het Oud rivierterrassenlandschap met esdek).

\subsubsection{Buitendijks rivierterrassenlandschap}

\section{Ruimtelijke situering, hoogteligging en reliëf}

Op een aantal plaatsen in het STEVIG-gebied loopt het rivierterrassenlandschap tot in het buitendijkse gebied door. In de meeste gevallen ligt het buitendijkse rivierterrassenlandschap ongeveer 2 meter hoger dan de nabijgelegen uiterwaarden. Er is sprake van vrij kleinschalige hoogteverschillen (ordegrootte meestal 0,5-1 m) in het buitendijks rivierterrassenlandschap. 


\section{Bodemopbouw en grondwatertrap}

De bodemopbouw is variabel. Deels gaat het om enkeerdgronden of veldpodzolgronden die wat betreft ontstaansgeschiedenis aansluiten bij de binnendijkse zandgronden, waarbij in het geval van de enkeerdgronden sprake is van een cultuurdek, ontstaan door het opbrengen van plaggen in het verleden. Deze bodems bevinden zich in de hoogste delen van het buitendijkse rivierterrassenlandschap en hebben hierdoor niet of nauwelijks onder invloed gestaan van de IJssel. Voor een ander deel bestaat de bodem van het buitendijkse rivierterrassenlandschap uit poldervaaggronden en ooivaaggronden, die karakteristiek zijn voor het buitendijkse rivierengebied en veelal ook in de uiterwaarden worden aangetroffen. Deze gronden zijn juist wel ontstaan onder invloed van overstromingen en sedimentafzetting door de IJssel. In het buitendijkse rivierterrassenlandschap zijn geen grondwatertrappen onderscheiden, omdat de grondwaterstand hier sterk beïnvloed wordt door de fluctuatie van de waterstand van de IJssel.

\section{Verkavelingsstructuur en historisch landgebruik}

Binnen het STEVIG-gebied vinden we het buitendijkse rivierterrassenlandschap terug als een aantal kleine landschappelijke zones (minder dan 1 ha tot ca. 25 ha), die enerzijds begrensd zijn door een dijk en anderzijds door het lager gelegen deel van het buitendijkse gebied. Beide grenzen kenmerken zich door een wat bochtig verloop. Door de wat bochtige begrenzing en de kleine oppervlaktes waarin dit landschapstype voorkomt, heeft de historische verkaveling zich sterk gericht op de mogelijkheden die de topografie bood. Het gevolg was een onregelmatige blokverkaveling. Het historisch landgebruik was wisselend: bouwland, grasland en - op de overgangen naar rivierduinen en op steilranden naar de uiterwaard - ook loofbos.

\section{Mate van openheid en karakteristieke landschapselementen}

Het buitendijkse rivierterrassenlandschap heeft op de Bonnekaart een halfopen tot open karakter. Op sommige plaatsen is het karakter halfopen door de aanwezigheid van bomenrijen op kavelgrenzen. Elders lijken deze op de Bonnekaart te ontbreken en is het landschap open.

Karakteristieke landschapselementen zijn:

- Terrasranden, die plaatselijk voorkomen op de grens naar het uiterwaardenlandschap. Plaatselijk zijn deze overgangen opgenomen in het dijklichaam van de winterdijk.

- Wielen (kolken die gevolg zijn van dijkdoorbraken in het verleden); deze zijn op de Bonnekaart her en der zichtbaar en waterhoudend, in het huidige landschap bevatten ze geen water meer, maar zijn ze als min of meer ronde depressie in het terrein nog zichtbaar.

- Oude dijken vormen her en der een deel van de begrenzing van dit landschapstype.

\section{Kenmerkende veld- of plaatsnamen}

De band die het buitendijkse rivierterrassenlandschap heeft met het binnendijkse zandgebied enerzijds en met het rivierengebied anderzijds, komt tot uitdrukking in namen als Overkamp (een kamp-naam aan de noordrand van het STEVIG-gebied) en Waterdijk ten zuiden van Gorssel.

\section{Kenmerken van de grens met andere landschapstypen}

De grens met het binnendijkse gebied wordt grotendeels gevormd door (winter)dijken en voor een klein deel door rivierduinen. Naar het lager gelegen buitendijkse gebied vinden we een steilrand of een meer geleidelijke overgang.

\section{Relatie met landschapstypenindeling uit LOP}

In het LOP is het buitendijkse rivierterrassenlandschap opgenomen in het landschapstype 'Uiterwaarden, kronkelwaarden, komgronden'. Mogelijk valt een klein deel van het buitendijkse rivierterrassenlandschap in het LOP onder het 'Enken/essenlandschap'. Dit kon op grond van vergelijking met de kleinschalige kaart in het LOP niet duidelijk worden bepaald. 


\subsubsection{Rivierterrassenlandschap}

\section{Ruimtelijke situering, hoogteligging en reliëf}

Binnendijks gelegen landschap dat qua hoogteligging, reliëf en ondergrond enerzijds nauw aansluit bij het Oude rivierterrassenlandschap met esdek, terwijl het anderzijds ook lagere en (voorheen) nattere terrassen omvat. Het verschil met het Oude rivierterrassenlandschap met esdek zit vooral in het ontbreken van het dikke cultuurdek van opgebrachte plaggen dat kenmerkend is voor essen.

\section{Bodemopbouw}

In de lagere delen van het Rivierterrassenlandschap vinden we overwegend beekeerd- en gooreerdgronden, soms met een klei- of zaveldek. Deze bodemtypen verwijzen naar een ontstaansgeschiedenis onder natte condities, deels met periodieke overstromingen. In de hogere delen van het Rivierterrassenlandschap komen vlakvaaggronden met een klei- of zaveldek (kZn23) en loopodzolgronden (cY23) voor. De grondwatertrappen in het rivierterrassenlandschap zijn III, V en VI.

\section{Verkavelingsstructuur en historisch landgebruik}

Binnen het STEVIG-gebied vinden we het Rivierterrassenlandschap terug als een aantal, deels kleine landschappelijke zones, die door hun onregelmatige begrenzing met andere landschapstypen en deels kleine oppervlak een onregelmatige blokverkaveling hebben. Deze situatie is vergelijkbaar met die van het buitendijkse rivierterrassenlandschap. Ook qua historisch landgebruik zijn er raakvlakken tussen het buitendijkse rivierterrassenlandschap en het Rivierterrassenlandschap: bouwland, grasland en plaatselijk loofbos en heide.

\section{Mate van openheid en karakteristieke landschapselementen}

Betrekkelijk gesloten landschap, deels door de kleine oppervlakten/schaal van dit landschapstype, deels door de aanwezigheid van opgaand hout. Karakteristieke landschapselementen zijn bomenrijen, houtsingels, (loof)bosstroken en kleine bosjes.

\section{Kenmerkende veld- of plaatsnamen}

Geen (op de Bonnekaart).

\section{Kenmerken van de grens met andere landschapstypen}

Een deel van het Rivierterrassenlandschap grenst via een winterdijk aan het buitendijkse gebied. Verder grenst het Rivierterrassenlandschap op een aantal plaatsen aan wat hoger gelegen landschapstypen zoals het Oude rivierterrassenlandschap met esdek, Rivierduinen en (hoger gelegen delen van) Jonge bos- en heideontginningen. Anderzijds grenst het Rivierterrassenlandschap lokaal ook aan beekdalen.

\section{Relatie met landschapstypenindeling uit LOP}

In het LOP is het Rivierterrassenlandschap opgenomen in het landschapstype 'Enken/essenlandschap'. Zowel op grond van het grotendeels ontbreken van een esdek als door de deels lage landschappelijke ligging onderscheiden wij het Rivierterrassenlandschap van het 'Enken/essenlandschap' uit het LOP.

\subsubsection{Oud rivierterrassenlandschap met esdek}

\section{Ruimtelijke situering, hoogteligging en reliëf}

De essen behoren tot de hogere delen van het projectgebied. Ze steken duidelijk af bij hun omgeving doordat ze wat hoger liggen, relatief weinig reliëf hebben op de top en vaak een tongvormige of ovale vorm hebben. De grootste es in het oud rivierterrassenlandschap met esdek, de Gorsselse Enk, heeft een afmeting van ca. 1,5 bij 2,5 km.

\section{Bodemopbouw en grondwatertrap}

De essen worden gekenmerkt door de aanwezigheid van enkeerdgronden. In het STEVIG-gebied treffen we enkeerdgronden aan die bestaan uit leemarm of (zwak) lemig fijn zand. Enkeerdgronden bestaan uit een humusrijke bruingekleurde laag grond van ten minste 50 centimeter dik. Deze gronden zijn ontstaan door bemesting met dierlijke mest en plaggen. Wanneer het ging om heideplaggen heeft dit geleid tot zwarte enkeerdgronden (zEZ21 en zEZ23). Wanneer het ging om 
door grassen gedomineerde plaggen leverde dat bruine enkeerdgronden op (bEZ21 en bEZ23). Als weerspiegeling van de aanwezige vegetatie werd deze laatste groep van plaggen vaker in beekdalen verzameld en de eerste meer in heidegebieden. In het STEVIG-gebied treffen we zowel bruine als zwarte enkeerdgronden aan. Er lijkt een relatie te bestaan tussen het bodemtype op het Oud rivierterrassenlandschap met esdek en de nabijheid van heidegronden (figuur 4.5). De grondwatertrappen in het rivierterrassenlandschap zijn VI en VII.

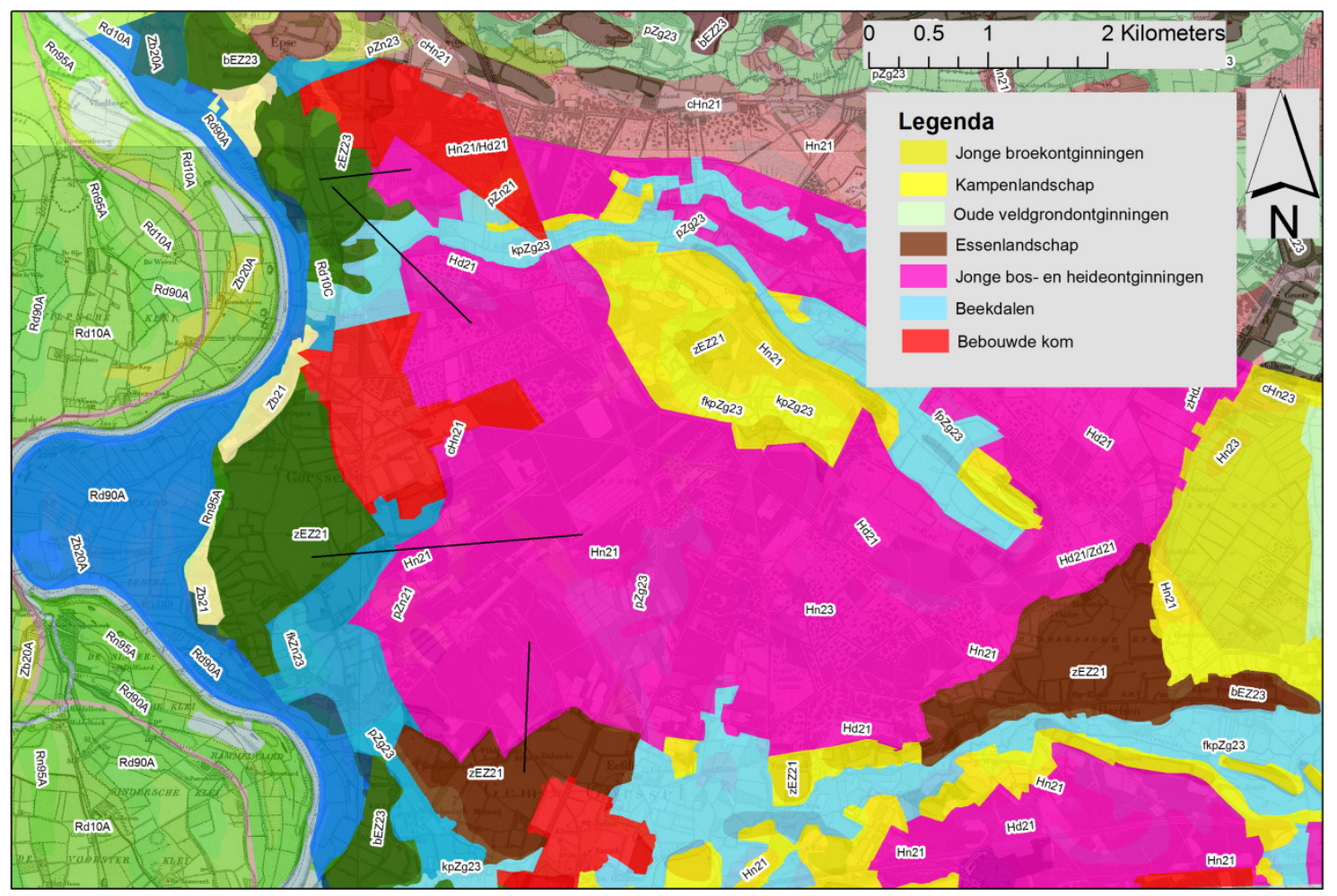

Figuur 4.5 Visualisatie van het mogelijke verband (zwarte lijnen) tussen de nabijheid van (voormalige) heidegronden (roze) en de aanwezigheid van zwarte enkeerdgronden (code zEZ..) op essen op het Oude rivierterrassenlandschap met esdek. De essen die behoren tot het Oude rivierterrassenlandschap met esdek en die op de zuid- en noordrand van de kaart liggen, hebben bruine enkeerdgronden (code bEZ..), wat aangeeft dat daar geen heideplaggen, maar grasrijke plaggen zijn gebruikt.

\section{Verkavelingsstructuur en historisch landgebruik}

Op de Bonnekaart van ca. 1900 springen de essen onmiddellijk in het oog, doordat ze de grootste aaneengesloten bouwlandcomplexen vormen (figuur 4.5). Heide ontbreekt volledig en grasland en bos ontbreken vrijwel op de essen. Wat opvalt, is dat houtsingels vaak wel voorkomen, maar bijna altijd in de randzone van een es. In het centrum van de es ontbraken opgaande perceelscheidingen. Dit betekent dat er vanuit militair oogpunt geen hindernissen waren zoals sloten of houtsingels.

Kavelgrenzen op de essen zijn daarom niet ingetekend op de Bonnekaart. Uit de kadastrale kartering van circa 1830 hebben we individuele perceelgroottes vastgesteld van ongeveer 0,1 tot circa 4 ha.

\section{Mate van openheid en karakteristieke landschapselementen}

De grotere essen hebben een vrij open karakter, doordat ze uit bouwlandpercelen bestaan en opgaande begroeiing langs de kavelgrenzen ontbreekt. De kleinere essen en de uitlopers van de grote essen hebben een meer gesloten karakter door hun kleinschaligheid en de sterkere aanwezigheid van houtsingels op de kavelgrenzen. Kenmerkende landschapselementen zijn kleine loofbosjes, bosstrookjes en houtsingels.

\section{Kenmerkende veld- of plaatsnamen}

Enk-namen, hoewel de Bonnekaart deze voor het Oude rivierterrassenlandschap met esdek nauwelijks vermeldt. 


\section{Kenmerken van de grens met andere landschapstypen}

De essen behoren tot de hoogste delen van het landschap en de overgang naar aangrenzende landschapstypen is deels vrij abrupt en zichtbaar als een steilrand (figuur 4.6).

\section{Relatie met landschapstypenindeling uit LOP}

Het LOP onderscheidt het 'Enken/essenlandschap' dat qua globale ligging overeenkomt met het door ons onderscheiden Essenlandschap. Het LOP maakt echter geen onderscheid tussen de essen in het IJsseldal en de verder oostelijk gelegen delen. Bovendien is het Enken/essenlandschap in het LOP veel ruimer begrensd dan de begrenzing van het Essenlandschap die wij in dit rapport hanteren en die sterk gekoppeld is aan het voorkomen van enkeerdgronden.

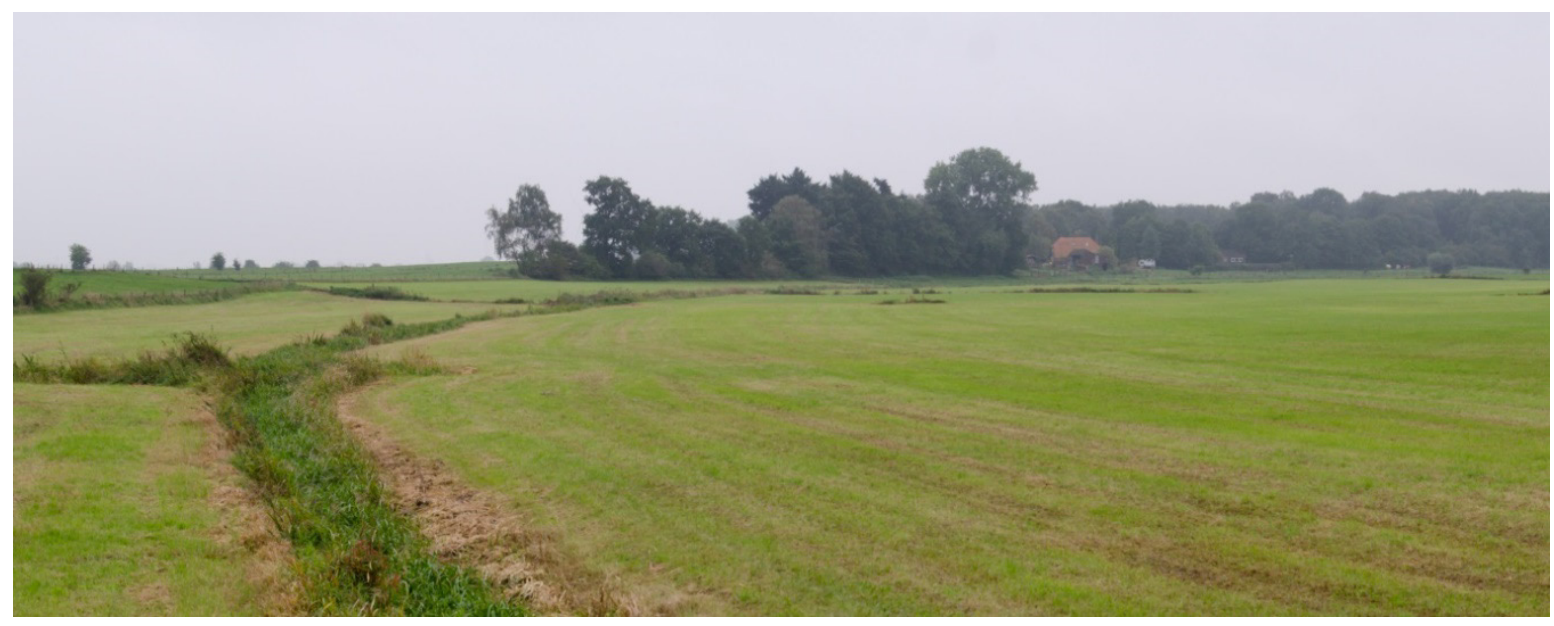

Figuur 4.6 Steilrand op de overgang van het uiterwaardenlandschap (voorgrond) naar het rivierterrassenlandschap (achtergrond links). Het bos op de achtergrond (rechts) is het rivierduinlandschap.

\subsection{Landschapstypen Dekzandgebied}

Binnen het dekzandgebied worden zes landschapstypen onderscheiden:

- Beekdallandschap

- Broekontginning

- Veldontginning

- Bos- en heideontginning

- Kampenlandschap

- Essenlandschap

De landschapstypen worden in volgorde van hun positie in het landschap van laag naar hoog behandeld. Vijf van de zes landschapstypen worden ook in het LOP beschreven. Het landschapstype veldontginning wordt als 'nieuw' landschap in deze reeks geïntroduceerd.

\subsubsection{Beekdalen}

\section{Ruimtelijke situering, hoogteligging en reliëf}

Globaal gezien lopen de beekdalen in het STEVIG-gebied van oost (bovenstrooms, flanken stuwwal Lochemerberg) naar west, waar de beken uitmonden in de IJssel. Uiteraard ligt het beekdallandschap laag ten opzichte van de meeste aangrenzende landschappen. Maar ook binnen het beekdallandschap is vaak sprake van (geringe) hoogteverschillen, bijvoorbeeld door de aanwezigheid van kleine dekzandruggen (figuur 4.7).

De beekdalen zijn plaatselijk opvallend breed gegeven de afmetingen van de beek die erdoorheen stroomt. Dit kan verklaard worden vanuit de geologische geschiedenis van dit deel van de Achterhoek. In de laatste ijstijd (ca. 100.000-10.000 jaar geleden) stroomde een vlechtende, grotere rivier (de voorloper van Berkel en IJssel) van het zuidoosten naar het noordwesten door de Achterhoek. Door 
bewegingen in de ondergrond verschoof deze rivier steeds verder naar het noorden. Tussen de verschillende takken van deze rivier werden door de wind dekzandruggen afgezet. In het projectgebied, tussen Berkel en Schipbeek, vinden we een aantal van deze oude rivierbeddingen terug in het landschap. Na de laatste ijstijd zijn kleinere beken, die hun oorsprong vinden in het hoger gelegen gebied net ten oosten van het projectgebied, deze oude rivierbeddingen gaan volgen richting de IJssel. Zo ontstonden de huidige beekdalen.

\section{Bodemopbouw en grondwatertrap}

De beekdalen worden gedomineerd door beekeerdgronden met lemig fijn zand (pZg23).

Beekeerdgronden bevatten een relatief vruchtbare humusrijke bovenlaag. Doordat de beekdalen laaggelegen zijn, is er (in het verleden) vaak sprake (geweest) van kwel. Dit uittredende grondwater bevat vaak veel opgelost ijzer, waardoor de bodems plaatselijk ijzerrijk zijn (toevoeging $\mathrm{f}$ ). De (voormalige) kwel en de daaruit voortkomende natte en zuurstofarme omstandigheden zijn verantwoordelijk voor de rijkdom aan organisch materiaal in deze bodems. Daarnaast komt door periodieke overstromingen lokaal in de beekdalen een zavel- of kleidek van $15-40 \mathrm{~cm}$ dik voor (toevoeging k). Het beekdal in de zuidoosthoek van het projectgebied vormt bodemkundig een geheel met het nabij gelegen huidige dal van het riviertje de Berkel, maar wordt daarvan gescheiden door het Twenthekanaal. De bodem bestaat daar uit ijzerrijke kalkloze poldervaaggronden met een dun cultuurdek die behoren tot de rivierkleigronden (fpRn59). De grondwatertrappen in de beekdalen zijn III en III*.

\section{Verkavelingsstructuur en historisch landgebruik}

De Bonnekaart ca. 1900 toont een onregelmatige blokverkaveling met soms gebogen kavelgrenzen (figuur 4.7) met percelen die meestal ca. 0,75-5 ha groot zijn, soms tot ca. 10 ha. Vanwege het relatief vochtige karakter van de laaggelegen beekdalen, is het landgebruik overwegend grasland. Hogere (dekzand)koepels binnen de beekdalen zijn vaak in gebruik als bouwland. Ook kleine loofbosjes komen plaatselijk voor in de beekdalen, zowel in zeer lage en natte delen (broekbos) als op wat hogere delen.

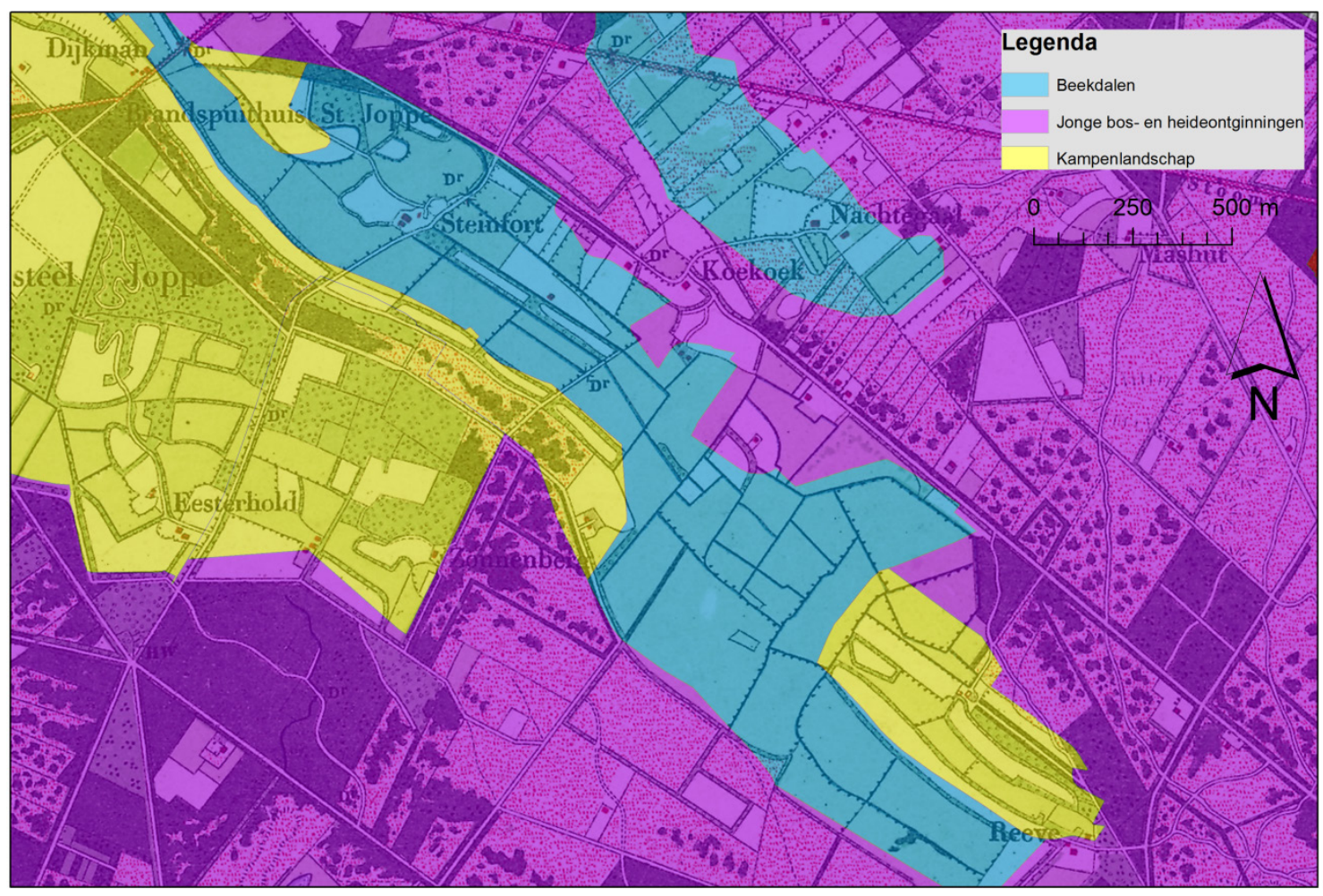

Figuur 4.7 Voorbeeld Beekdallandschap ten oosten van Kasteel Joppe. Zichtbaar zijn de bomenrijen op graslandkavelgrenzen en de 'dichtere' houtsingels langs (akker)percelen, vergelijkbaar met die in het Kampenlandschap. De akkerpercelen liggen relatief hoog en droog op zandopduikingen in het beekdallandschap. NB De landschapstypen zijn begrensd op de huidige topografie. 


\section{Mate van openheid en karakteristieke landschapselementen}

Halfopen landschap door vrij algemene aanwezigheid van bomenrijen op graslandkavelgrenzen en door de doorgaans beperkte breedte van het Beekdallandschap (doorgaans ca. 200-500, soms tot ca. $800 \mathrm{~m}$ ). Karakteristieke landschapselementen: bomenrijen op graslandkavelgrenzen, sloten die als grens tussen de graslandpercelen fungeren, plaatselijk kleine (broek)loofbosjes. De her en der voorkomende akkers zijn vaak omgeven door (hak)houtstroken. Langs de Heurnerbeek ten zuiden van Laren vinden we - aansluitend bij het aangrenzende Kampenlandschap - ook houtsingels rond de graslandpercelen.

\section{Kenmerkende veld- of plaatsnamen}

Behalve de beek-waternamen, vinden we op de Bonnekaart 1900 in het Beekdallandschap her en der veldnamen die op een natte omgeving wijzen, zoals Moespot en Marshave (langs de Dommerbeek, ten noorden van Joppe; 'moes' en 'mars' verwijzen naar een moerassig of venig gebied).

\section{Kenmerken van de grens met andere landschapstypen}

De overgang van het Beekdallandschap naar hoger gelegen landschapstypen zoals de Jonge bos- en heideontginningen, het Kampenlandschap of het Essenlandschap, is in het veld her en der zichtbaar als een steilrand (figuur 4.8). Vaak is de overgang echter ook subtiel en niet goed zichtbaar.

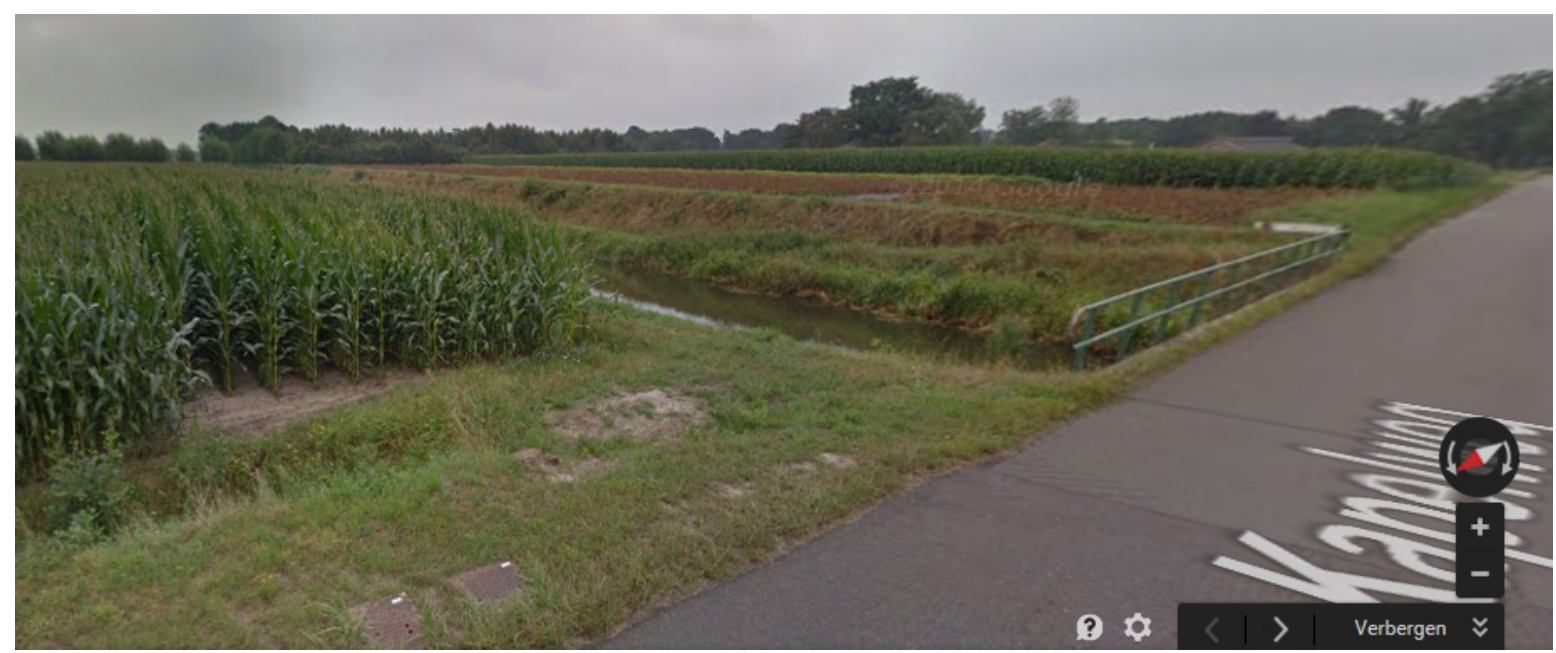

Figuur 4.8 Steilrand op overgang Beekdallandschap naar Essenlandschap, op de foto direct aan de overzijde van de Eefsebeek. Zicht vanaf de Kapelweg bij Almen richting zuidoosten. Bron: Google Streetview.

\section{Relatie met landschapstypenindeling uit LOP}

In het LOP (Landschapsontwikkelingsvisie Gemeenten Bronckhorst-Lochem-Zutphen, 2009, p. 72) vinden we het Beekdallandschap in het grootste deel van het projectgebied terug als landschapstype 'Beekdal'. In het noordoostelijke deel van het projectgebied, tussen de Koelerweg in het westen en Laren, wordt het Beekdallandschap niet apart onderscheiden in het LOP, maar maakt het onderdeel uit van het 'Enken-/essenlandschap' en het 'Kampenlandschap'.

\subsubsection{Jonge broekontginningen}

\section{Ruimtelijke situering, hoogteligging en reliëf}

In het projectgebied vinden we het Broekontginningen-landschap in het Emsbroekgebied tussen Harfsen en Laren. Ongeveer halverwege loopt van noord naar zuid een brede hoger gelegen rug. Deze stuwt als het ware het van oost naar west afstromende (grond)water op, waardoor zich ten oosten van de rug een broeklandschap kon vormen, dat in 1850 al (deels) ontwaterd en ontgonnen blijkt, getuige de Topografisch-Militaire Kaart (TMK).

Net als het Beekdallandschap ligt het Broekontginningen-landschap laag ten opzichte van de aangrenzende Essen- en Kampenlandschappen en Jonge bos- en heideontginningen. Toch is ook binnen het Broekontginningen-landschap sprake van lokale (geringe) hoogteverschillen, bijvoorbeeld door de aanwezigheid van kleine dekzandruggen. 


\section{Bodemopbouw en grondwatertrap}

Het bodemvorming in het van oorsprong zeer natte Broekontginningen-landschap heeft veel raakvlakken met die in de Beekdalen (zie hierboven). Net als in de beekdalen wordt het Jonge Broekontginningen-landschap gekenmerkt door beekeerdgronden met lemig fijn zand die behoren tot de kalkloze zandgronden (pZg23). De grondwatertrappen in de jonge broekontginningen zijn III, III*, $\checkmark$ en $V^{*}$.

\section{Verkavelingsstructuur en historisch landgebruik}

De Jonge broekontginning van het Emsbroek toont een vrij regelmatige en rationele blokverkaveling die duidt op een relatief late ontginning (figuur 4.9). Het dominante historische landgebruik is grasland. In het laaggelegen centrale deel van het Emsbroek komt volgens de Bonnekaart 1900 over een oppervlakte van zo'n 2 ha moeras voor. In het zuidelijke deel van het gebied liggen her en der kleine perceeltjes heide. De combinatie van de Bonnekaart met de bodemkaart laat zien dat deze heitjes kennelijk op beekeerdgrond liggen. Plaatselijk is er ook opslag van naaldhout volgens de Bonnekaart.

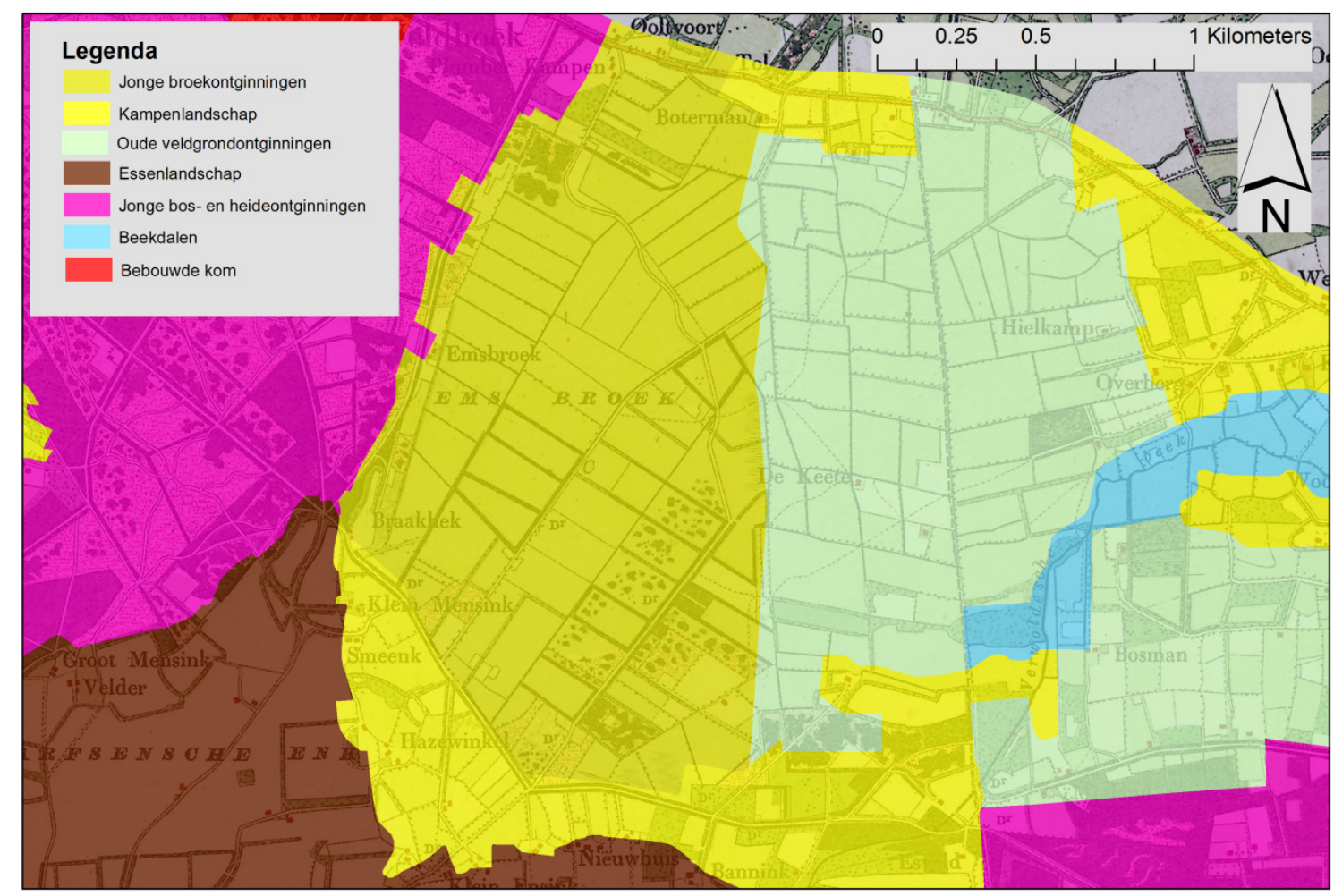

Figuur 4.9 Jonge broekontginningen-landschap van het Emsbroek op de Bonnekaart van ca. 1900.

\section{Mate van openheid en karakteristieke landschapselementen}

Door de aanwezigheid van houtsingels op kavelgrenzen en van plaatselijke opslag van (naald)hout is het Jonge broekontginningen-landschap halfopen, vergelijkbaar met het Beekdallandschap. Karakteristieke landschapselementen van het Jonge broekontginningen-landschap zijn sloten, bomenrijen en houtsingels.

\section{Kenmerkende veld- of plaatsnamen}

De broek-veldnaam 'Emsbroek'.

\section{Kenmerken van de grens met andere landschapstypen}

De overgang naar de ten westen van het Emsbroek gelegen brede rug met daarop Jonge bos- en heideontginningen is qua reliëf het meest uitgesproken. Ook de overgang naar het Kampenlandschap is relatief abrupt qua hoogteligging. Aan de oostrand is de overgang naar de Oude broekontginningen qua reliëf en bodemkundig geleidelijk. 


\section{Relatie met landschapstypenindeling uit LOP}

Het LOP onderscheidt een landschapstype 'Broeklanden' dat wat breder begrensd is dan het door ons onderscheiden Broekontginningen-landschap van het Emsbroek. In het LOP wordt het oostelijke deel van het Emsbroek, dat door zijn verkaveling afwijkt van het westelijke deel en dat wij tot de Oude broekontginningen rekenen, gerekend tot het landschapstype 'Broeklanden'.

\subsubsection{Oude broekontginningen}

\section{Ruimtelijke situering, hoogteligging en reliëf}

In het STEVIG-gebied onderscheiden we een aantal Oude broekontginningen. Sommige daarvan liggen laag in het landschap, andere hoger. In het eerste geval zal in het verleden sprake zijn geweest van een moeras-, broekbos- of natte heidevegetatie. Een voorbeeld van een laaggelegen natte Oude broekontginning is de oostelijke helft van het Emsbroek. Iets oostelijker vinden we juist een hogere en drogere Oude broekontginning die aansluit bij een kampenlandschap (figuur 4.9). Binnen de Oude broekontginningen is sprake van enig hoogteverschil, waarbij de hooggelegen delen op de Bonnekaart terug te vinden zijn als akkers.

\section{Bodemopbouw en grondwatertrap}

De bodemsamenstelling van de laaggelegen Oude broekontginningen heeft veel raakvlakken met de Beekdalen en de Jonge broekontginningen. Landschappelijk gaan deze historische landschappen binnen het STEVIG-gebied vloeiend in elkaar over. Kenmerkende bodemtypen voor dit landschap zijn gooreerdgronden ( $p$ Zn23) en beekeerdgronden (pZg23) in lemig fijn zand, al dan niet met klei- of zaveldek, wat wijst op invloed van periodieke overstroming met beekwater in het verleden. Voor meer informatie over deze bodemtypen verwijzen we naar de paragraaf Beekdalen. In de hoger gelegen delen van het Oude broekontginningen vinden we ook laarpodzolgronden ( $\mathrm{cHn} 23$ ). Deze bestaan uit lemig fijn zand. De grondwatertrappen in de oude broekontginningen zijn III, III*, V en V*.

\section{Verkavelingsstructuur en historisch landgebruik}

Kenmerkend voor de Oude broekontginningen is een kleinschalige, vrij regelmatige blokverkaveling. Op de Bonnekaart kunnen we de Oude broekontginningen dankzij deze verkavelingsstructuur onderscheiden van de aangrenzende Jonge broekontginningen, Beekdalen en Kampenlandschappen. De Oude broekontginning in het oostelijke deel van het Emsbroek heeft op de Bonnekaart percelen van ca. 0,75 tot ca. 5 ha groot. Het historisch landgebruik is overwegend grasland, op hoger gelegen delen ook bouwland. Daarnaast kleine loofbosjes.

\section{Mate van openheid en karakteristieke landschapselementen}

Vrij open landschap met bomenrijen op kavelgrenzen, vooral in de grotere gebieden. In de kleinere, oude broekontginningen ook vrij veel houtsingels langs sloten op kavelgrenzen en kleine loofbosjes.

\section{Kenmerkende veld- of plaatsnamen}

De veldnaam 'De Slagen' is mogelijk een verwijzing naar de vrij regelmatige verkaveling (Van Petersen, 2002).

\section{Kenmerken van de grens met andere landschapstypen}

Zowel de laaggelegen als de hoger gelegen varianten van de Oude broekontginningen kenmerken zich door een onduidelijke overgang naar de aangrenzende landschapstypen (Beekdal, Jonge broekontginningen, Kampenlandschap).

\section{Relatie met landschapstypenindeling uit LOP}

Het LOP onderscheidt geen landschapstype Oude broekontginningen. Dit landschapstype is in het LOP onderdeel van de typen 'Broeklanden', 'Kampenlandschap' en mogelijk 'Enken/essenlandschap'. Dit laatste kon door de kleinschaligheid van de landschapstypenkaart in het LOP niet goed worden nagegaan. 


\subsubsection{Essenlandschap}

In de Achterhoek is de benaming 'enk' in plaats van 'es' gangbaar. We zien dit terug in de veldnamen in het STEVIG-gebied. In navolging van de vakliteratuur gebruiken we hier de term 'es' als generieke benaming voor landschappelijke eenheden met regionaal verschillende namen (es, eng, enk).

\section{Ruimtelijke situering, hoogteligging en reliëf}

De essen behoren tot de hoogste delen van het projectgebied. Ze steken duidelijk af bij hun omgeving doordat ze wat hoger liggen, relatief weinig reliëf hebben op de top en vaak een tongvormige of ovale vorm hebben. De grootste essen in het projectgebied hebben een afmeting van 1,5 bij 2 of 1,5 bij $3 \mathrm{~km}$. Daarnaast zijn er in het projectgebied kleinere uitlopers van essen die net ten oosten van het projectgebied liggen, zoals in de omgeving van Laren.

We maken onderscheid tussen de essen die in de nabijheid van de IJssel liggen (Oud rivierterrassenlandschap met esdek) en de verder naar het oosten gelegen essen (Essenlandschap).

\section{Bodemopbouw en grondwatertrap}

De essen worden gekenmerkt door de aanwezigheid van enkeerdgronden. In het STEVIG-gebied treffen we enkeerdgronden aan die bestaan uit leemarm tot lemig fijn zand. Enkeerdgronden bestaan uit een humusrijke bruingekleurde laag grond van ten minste 50 centimeter dik. Deze gronden zijn ontstaan door bemesting met dierlijke mest en plaggen (https://nl.wikipedia.org/wiki/Enkeerdgronden). Wanneer het ging om heideplaggen heeft dit geleid tot zwarte enkeerdgronden (zEZ23). Wanneer het ging om door grassen gedomineerde plaggen leverde dat bruine enkeerdgronden (bEZ23) op. Als weerspiegeling van de aanwezige vegetatie werd deze laatste groep van plaggen vaker in beekdalen verzameld en de eerste meer in heidegebieden. In het STEVIG-gebied treffen we zowel bruine als zwarte enkeerdgronden aan. De correlatie van bruine enkeerdgronden met beekdalen is hier niet heel duidelijk. Nabij de IJssel (Oude rivierterrassenlandschap met esdek) lijkt de relatie tussen nabijheid van heidegebieden en het gebruik van heideplaggen op de es duidelijker. De grondwatertrap op de essen is VII.

\section{Verkavelingsstructuur en historisch landgebruik}

Op de Bonnekaart van ca. 1900 springen de essen onmiddellijk in het oog, doordat ze de grootste aaneengesloten bouwlandcomplexen vormen (figuur 4.10). Heide ontbreekt volledig en grasland en bos ontbreken vrijwel op de essen. Wat opvalt, is dat houtsingels vaak wel voorkomen, maar bijna altijd in de randzone van een es. Soms begrenzen ze de es, zoals bij de Wester Enk van Laren (figuur 4.11) en soms begrenzen ze individuele percelen, vooral in de periferie van de es, bijvoorbeeld bij de Harfsensche Enk (figuur 4.12). In het centrum van de es ontbraken opgaande perceelscheidingen. Dit betekent dat er vanuit militair oogpunt geen hindernissen waren zoals sloten of houtsingels. Kavelgrenzen op de essen zijn daarom niet ingetekend op de Bonnekaart. Uit de kadastrale kartering van circa 1830 hebben we aan de hand van het voorbeeld van de Harfsensche Enk individuele perceelgroottes vastgesteld van ongeveer 0,1 tot circa 4 ha. 


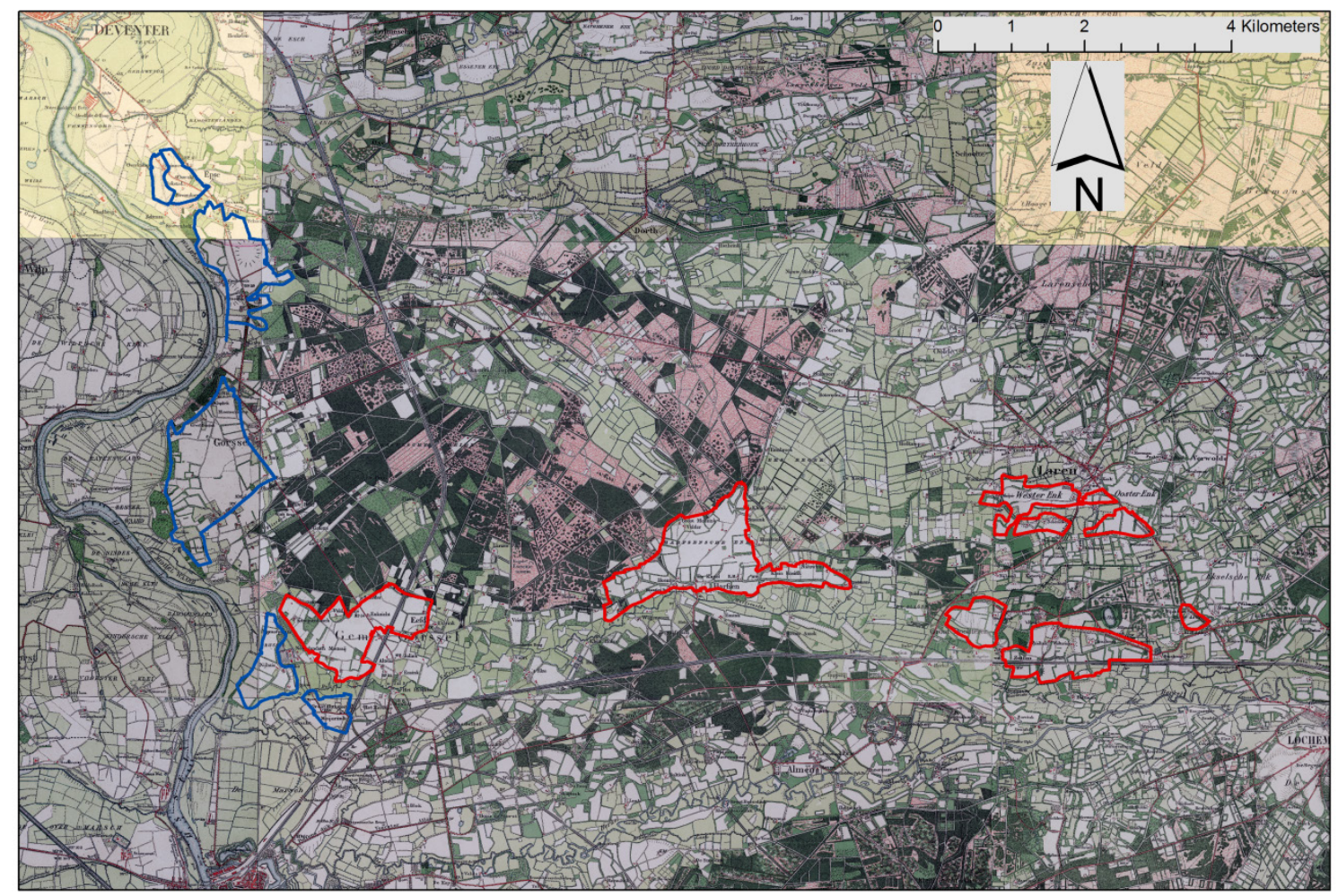

Figuur 4.10 Overzichtskaart STEVIG-gebied met als topografische achtergrond de Bonnekaart van omstreeks 1900. Blauw begrensd zijn de essen van het Oude rivierterrassenlandschap met esdek; rood begrensd de essen van het Essenlandschap. Beide landschapstypen herbergen de grootste aaneengesloten bouwlandcomplexen in het gebied.

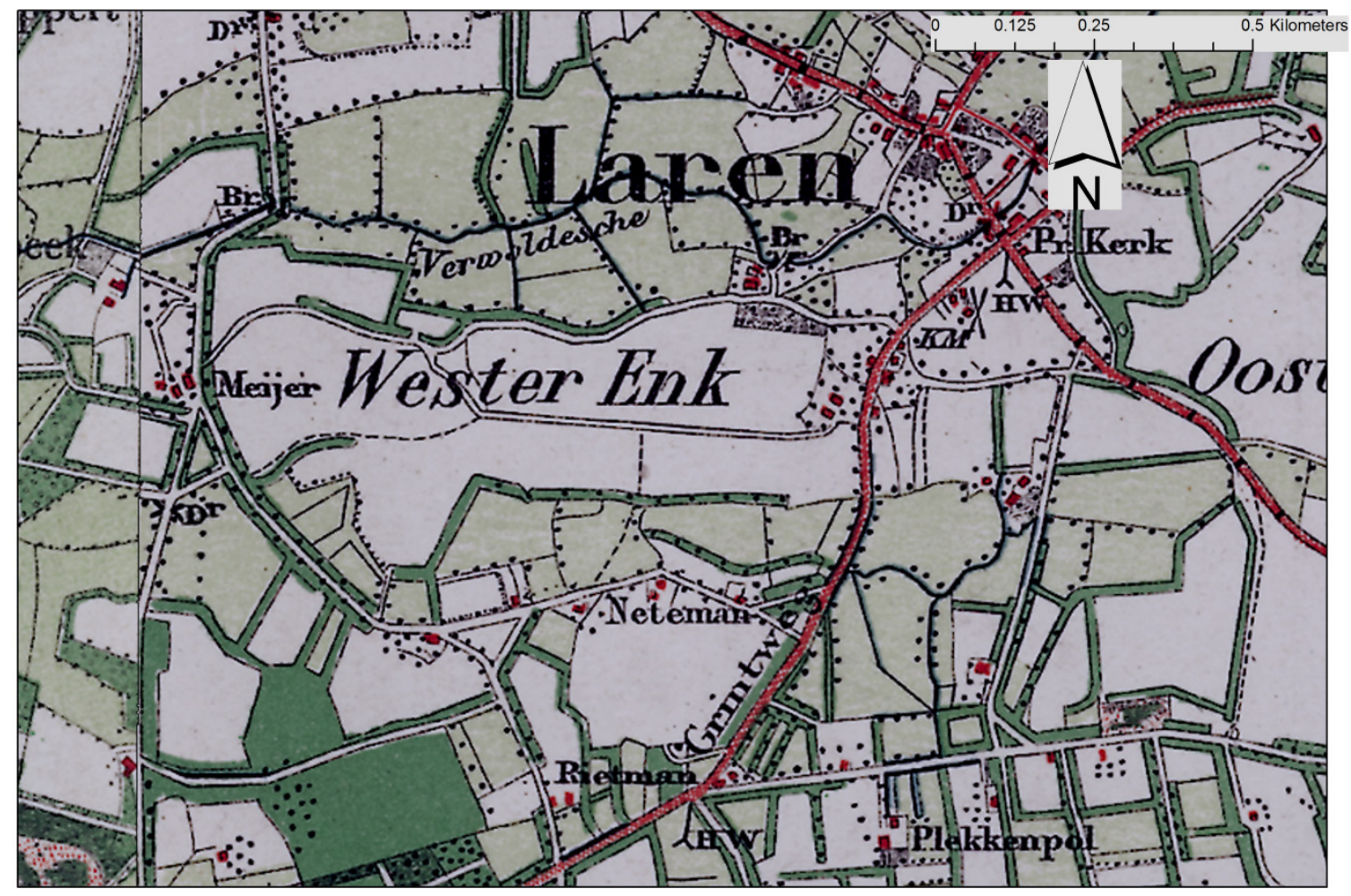

Figuur 4.11 Houtsingel langs de rand van een es; Wester Enk bij Laren. 


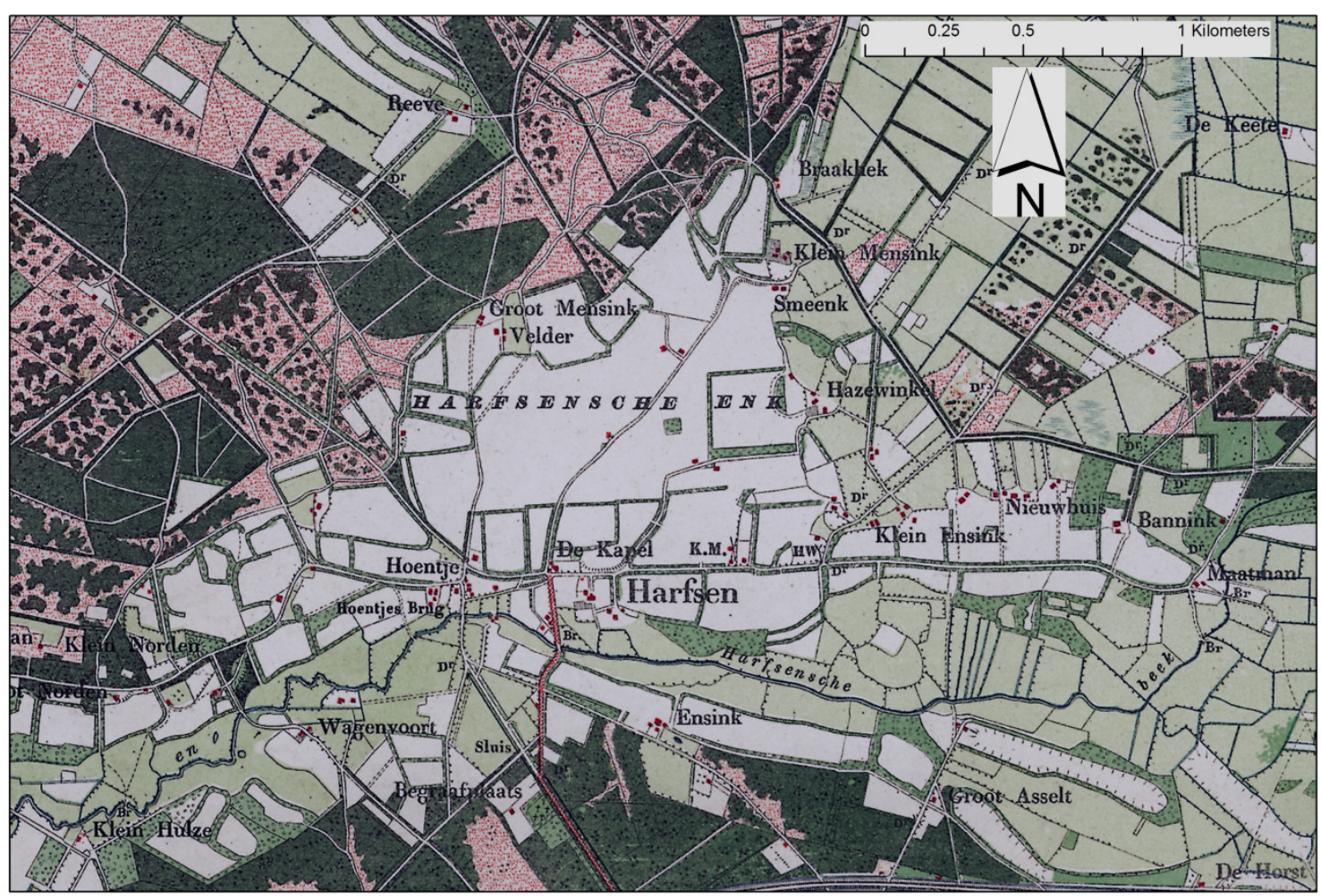

Figuur 4.12 Houtsingel langs individuele percelen in de periferie van een es. Harfsensche Enk.

\section{Mate van openheid en karakteristieke landschapselementen}

De grotere essen hebben een vrij open karakter, doordat ze uit bouwlandpercelen bestaan en opgaande begroeiing langs de kavelgrenzen ontbreekt. De kleinere essen en de uitlopers van de grote essen hebben een meer gesloten karakter door hun kleinschaligheid en de sterkere aanwezigheid van houtsingels op de kavelgrenzen. Vooral op de Eefdese Enk aan de randen ook kleine loofhoutbosjes en bosstrookjes die breder zijn dan een houtsingel.

\section{Kenmerkende veld- of plaatsnamen}

Diverse enk-typoniemen, meestal in combinatie met een plaatsnaam, bijvoorbeeld Harfsensche Enk, maar soms ook boerderijnamen, zoals Enkzicht bij Eefde.

\section{Kenmerken van de grens met andere landschapstypen}

De essen behoren tot de hoogste delen van het landschap en de overgang naar aangrenzende landschapstypen is deels vrij abrupt en zichtbaar als een steilrand.

\section{Relatie met landschapstypenindeling uit LOP}

Het LOP onderscheidt het 'Enken/essenlandschap' dat qua globale ligging overeenkomt met het door ons onderscheiden Essenlandschap. Het LOP maakt echter geen onderscheid tussen de essen in het IJsseldal en de verder oostelijk gelegen delen. Bovendien is het Enken/essenlandschap in het LOP veel ruimer begrensd dan de begrenzing van het Essenlandschap die wij in dit rapport hanteren en die sterk gekoppeld is aan het voorkomen van enkeerdgronden.

\subsubsection{Jonge bos- en heideontginningen}

\section{Ruimtelijke situering, hoogteligging en reliëf}

De Jonge bos- en heideontginningen vormen qua oppervlak het belangrijkste landschapstype in het projectgebied (figuur 4.3). De hoogteligging is variabel, wat in het oorspronkelijke heidelandschap tot uitdrukking kwam als droge heide (hoog) en natte heide (laag). In vergelijking met de hooggelegen en relatief vlakke essen is het reliëf in de Jonge bos- en heideontginningen meestal wat grilliger door de aanwezigheid van dekzandruggen en laagten. De grootste aaneengesloten Jonge bos- en heideontginningen vinden we in het westelijke deel van het projectgebied tussen Eefde, Gorssel en Harfsen. 


\section{Bodemopbouw en grondwatertrap}

- In vergelijking met de voorgaande landschapstypen is de bodemsamenstelling heterogener. Globaal genomen vinden we in de Jonge bos- en heideontginningen vooral podzolgronden. Dit zijn zandgronden waarin mineralen en humus zijn uitgespoeld uit de bovenste bodemlaag, die daardoor asgrijs van kleur is. Iets dieper bevindt zich een donkere inspoelingslaag waar de mineralen en humus zijn blijven zitten. Podzolgronden zijn in het algemeen kalkloze en voedselarme gronden, waardoor ze voor de landbouw minder geschikt zijn. Er zijn diverse typen podzolgronden, waarbij in de Jonge bos- en heideontginningen in het STEVIG-gebied de veldpodzolgronden een belangrijke plaats innemen. Deze zijn ontstaan onder condities met hoge grondwaterstanden (natte heide). Op de hoger gelegen droge delen in dit landschapstype komen haarpodzolgronden voor (Hd21). De podzolgronden in dit landschapstype bestaan uit leemarm tot zwaklemig fijn zand. In natte laagten in de Jonge bos- en heideontginningen komen we in uitlopers van beekdalen lemige beekeerdgronden (pZg23) (zie onder Beekdalen) en, in meer geïsoleerde laagten, gooreerdgronden ( $\mathrm{ZZn21)}$ tegen. Gooreerdgronden worden voornamelijk gevoed door regenwater en plaatselijk door basenarm grondwater. Ze zijn ontstaan in nattere, lager gelegen delen in het Pleistocene zandlandschap. Gooreerdgronden vormen een overgang tussen beekeerdgronden en podzolgronden. De grondwatertrappen in de jonge bos- en heideontginningen zijn III, V en V*, VI en VII.

\section{Verkavelingsstructuur en historisch landgebruik}

Opvallende kenmerken op de Bonnekaart (ca. 1900) zijn de rechte wegtracés die soms in een stervorm bij elkaar komen en de naaldboombeplantingen. Beide wijzen op een relatief jonge ontginning en verkaveling. Daarnaast is ook typerend de aanwezigheid van relatief grote oppervlakten heide op de Bonnekaart.

De perceelgrootte varieert sterk. De meeste percelen liggen qua oppervlakte tussen 1 en 10 ha, maar kleinere en grotere percelen komen ook voor.

\section{Mate van openheid en karakteristieke landschapselementen}

De Jonge bos- en heideontginningen vormen een overwegend halfopen tot gesloten landschap, omdat grote delen rond 1900 al bebost zijn of bestaan uit heide waar opslag van naaldbomen plaatsvindt. Op de Bonnekaart 1900 zijn in de heidepercelen naald- en loofbos, inclusief kleine bosjes en spontane bosopslag zichtbaar. Houtsingels langs percelen en wegen (lanen) bestaan vaak uit naaldhout.

\section{Kenmerkende veld- of plaatsnamen}

Naast Heide-namen komen we hier en daar ook namen met veld tegen, bijvoorbeeld Veldhoek. Interessant is ook de veldnaam Plakhutte ten zuiden van Veldhoek. Dit verwijst mogelijk naar een plaggenhut.

\section{Kenmerken van de grens met andere landschapstypen}

De grens van de Jonge bos- en heideontginningen met andere historische landschapstypen is in sommige gevallen zichtbaar in het reliëf, bijvoorbeeld een dekzandrug die de grens vormt met een beekdal of een steilrand naar het Essenlandschap (figuur 4.12). Vaak echter is er qua hoogteligging geen duidelijke grens aan te geven en wordt de afgrenzing van de Jonge bos- en heideontginningen vooral bodemkundig bepaald. 


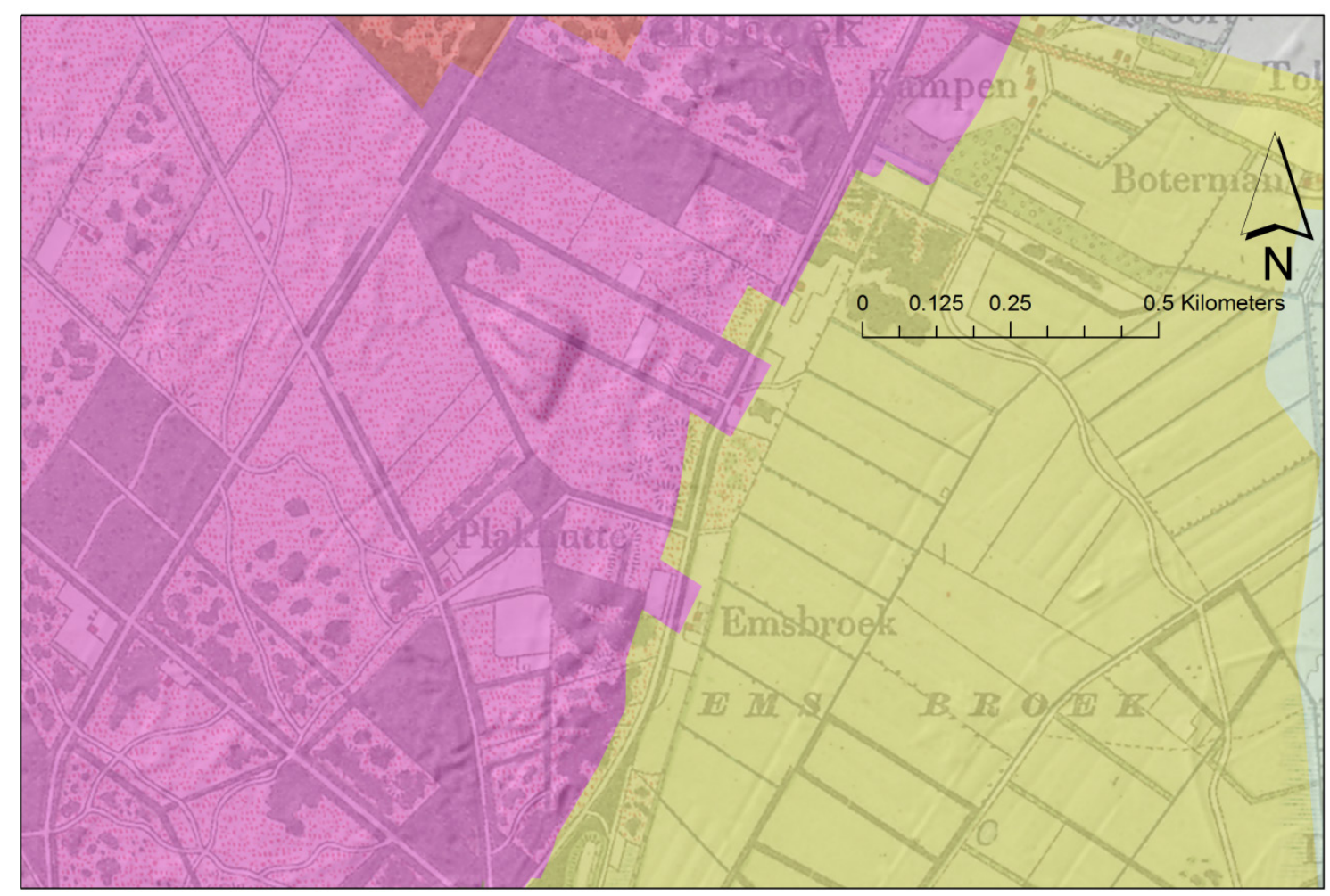

Figuur 4.13 Een zandrug vormt de grens tussen de Jonge bos- en heideontginning (roze gekleurd) en het Emsbroek.

\section{Relatie met landschapstypenindeling uit LOP}

Het LOP onderscheidt het landschapstype 'Bos en landgoederen' dat qua globale ligging overeenkomt met de door ons onderscheiden Jonge bos- en heideontginningen. Meer in detail komen de begrenzingen echter niet overeen. De Jonge bos- en heideontginningen die wij in het oostelijke deel van het STEVIG-gebied onderscheiden, vallen in het LOP onder het 'Kampenlandschap' resp. onder het 'Enken/essenlandschap'.

\section{Overige bijzonderheden}

Rond 1900 vinden we een aantal (voormalige) militaire terreinen in de grote Jonge bos- en heideontginningen tussen Eefde, Gorssel en Harfsen. Buiten dit landschapstype komen we in het projectgebied geen militaire terreinen tegen. Dit geldt in grote lijnen ook voor overig Nederland.

\subsubsection{Kampenlandschap}

\section{Ruimtelijke situering, hoogteligging en reliëf}

Het historische landschapstype Kampenlandschap vinden we op een aantal plaatsen verspreid over het projectgebied. De hoogteligging is variabel en varieert ook binnen het Kampenlandschap, waar het hoogtebestand AHN2 typisch een vrij grillig en kleinschalig reliëf laat zien. Typerend is dat de hoogste delen van het Kampenlandschap vaak bestaan uit kleine esjes ('eenmansessen').

\section{Bodemopbouw en grondwatertrap}

Het historische landschapstype Kampenlandschap wordt gekenmerkt door een afwisseling in bodemtypen, die samenhangt met de hiervoor beschreven (kleinschalige) hoogteverschillen en daarmee samenhangende vochthuishouding. Grofweg kan een tweedeling gemaakt worden in 1) relatief hoog en droog, podzolgronden en enkeerdgronden 2) laag en vochtig tot natte beekeerdgronden ( $p$ Zg23), plaatselijk ijzerrijk of met een zavel- of kleidek (toevoeging $\mathrm{f} / \mathrm{k}$ ) of gooreerdgronden (pZn23). De grondwatertrappen in de jonge broekontginningen zijn III, V en VII. 


\section{Verkavelingsstructuur en historisch landgebruik}

Het historische landschapstype Kampenlandschap wordt gekenmerkt door een (zeer) onregelmatige blokverkaveling. Dit lijkt direct samen te hangen met de variatie in hoogteligging en bodemsamenstelling die we er tegenkomen. Deze variatie uit zich verder in het feit dat binnen het Kampenlandschap meestal een (kleinschalige) afwisseling voorkomt van - vaak met houtsingels omzoomd - bouwland (bijv. op eenmansessen), grasland en kleine stukken bos (figuur 4.13). Door deze kleinschalige fysieke variatie is ook het wegenpatroon op de Bonnekaart 1900 soms nog vrij grillig.

In het historische Kampenlandschap vinden we een afwisseling van zeer kleine tot middelgrote en soms grote percelen (range $<0,5$ ha tot ca. 5 ha, max. 10 ha).

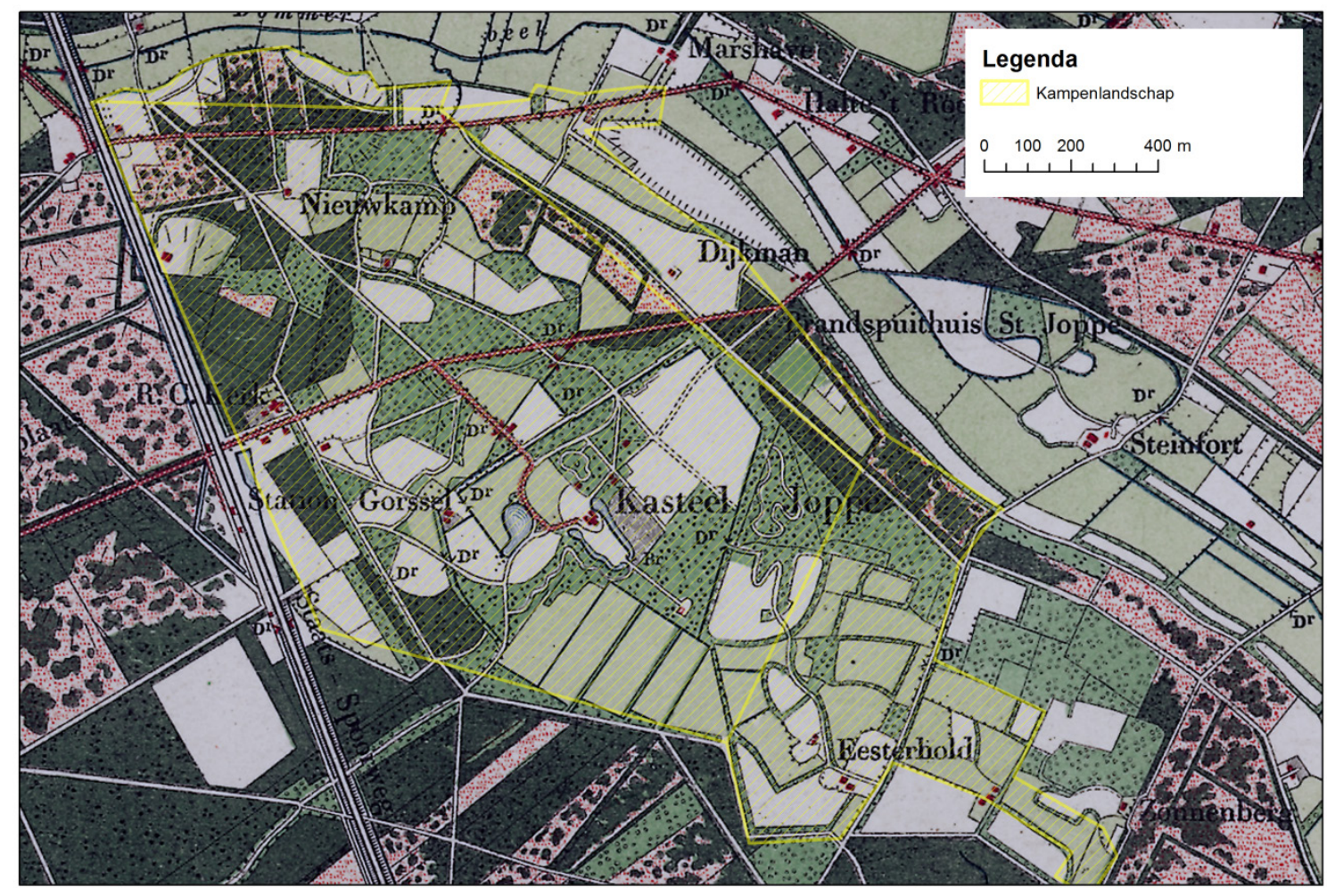

Figuur 4.14 Afwisselend landgebruik en onregelmatige blokverkaveling in Kampenlandschap bij Kasteel Joppe. Bonnekaart 1900.

\section{Mate van openheid en karakteristieke landschapselementen}

Het historische Kampenlandschap heeft een betrekkelijk gesloten karakter door de vaak relatief kleine percelen en de grote rijkdom aan houtige landschapselementen op de kavelgrenzen (figuur 4.13). Kleine bossen en bosjes (vooral loofhout) en singels van loofhout rond de percelen. Verder ook bomenrijen (onderbroken dus i.t.t. houtsingel) op kavelgrenzen en langs wegen.

\section{Kenmerkende veld- of plaatsnamen}

Behalve kamp-veldnamen zoals Hielkamp en Nieuwkamp, komen we op de Bonnekaart 1900 in een van de Kampenlandschappen de naam 'Koterij' tegen. We nemen aan dat deze naam verwijst naar een ook in het verleden als kleinschalig opgevat agrarisch bedrijf en beschouwen deze als kenmerkend voor de schaalbegrenzing die het Kampenlandschap (met bovendien een kleinschalige afwisseling tussen vruchtbare en minder vruchtbare bodems) van oudsher bood aan boeren.

\section{Kenmerken van de grens met andere landschapstypen}

In het hoogtebestand AHN2 is de overgang van het Kampenlandschap naar lager gelegen landschapstypen zoals het Beekdallandschap goed zichtbaar. Ook de eenmansessen binnen het Kampenlandschap steken qua hoogteligging meestal duidelijk af tegen hun omgeving. In het veld zien we deze overgangen soms als een steilrand. Vaak is de overgang echter ook subtiel en niet goed zichtbaar. 


\section{Relatie met landschapstypenindeling uit LOP}

Het Kampenlandschap wordt ook onderscheiden in het LOP, maar wat opvalt, is dat de kartering ervan sterk afwijkt van de onze. Alleen in het Kampenlandschap direct ten oosten van het Emsbroekgebied zit overlap tussen beide karteringen. De Kampenlandschappen die wij onderscheiden, enerzijds rond het dal van de Eefsebeek stroomopwaarts van Eefde en rond Kasteel het Joppe en anderzijds tussen Lochem en Laren en in het noorden van het projectgebied nabij de IJssel, zijn als 'Bos- en landgoederenlandschap' resp. als 'Enken/essenlandschap' gekarteerd in het LOP. Omgekeerd onderscheidt het LOP een Kampenlandschap ten noorden van de Dommerbeek, dat wij karteren als Jonge bos- en heideontginningen. 


\section{$5 \quad$ Bouwstenen}

Op basis van wensen en ambities van alle betrokken partijen zijn door Alterra voor elk landschapstype bouwstenen opgesteld. Deze conceptbouwstenen zijn vervolgens besproken in de begeleidingsgroep en na aanpassing vastgesteld. Op basis van de bouwstenen wordt later in de cascobenadering voor elk opgaand groen landschapselement bepaald of het een onderdeel is van de kenmerkende structuur van dat betreffende landschap, het casco, of niet. Ook geven de bouwstenen richting aan de gewenste kavelvergroting, om tegemoet te komen aan de wens tot structuurversterking voor de landbouw.

\subsection{Generieke bouwstenen}

Tabel 5.1 Generieke bouwstenen

\begin{tabular}{|c|c|}
\hline Opgave & en \\
\hline Behoud \& ontwikkeling landschap & 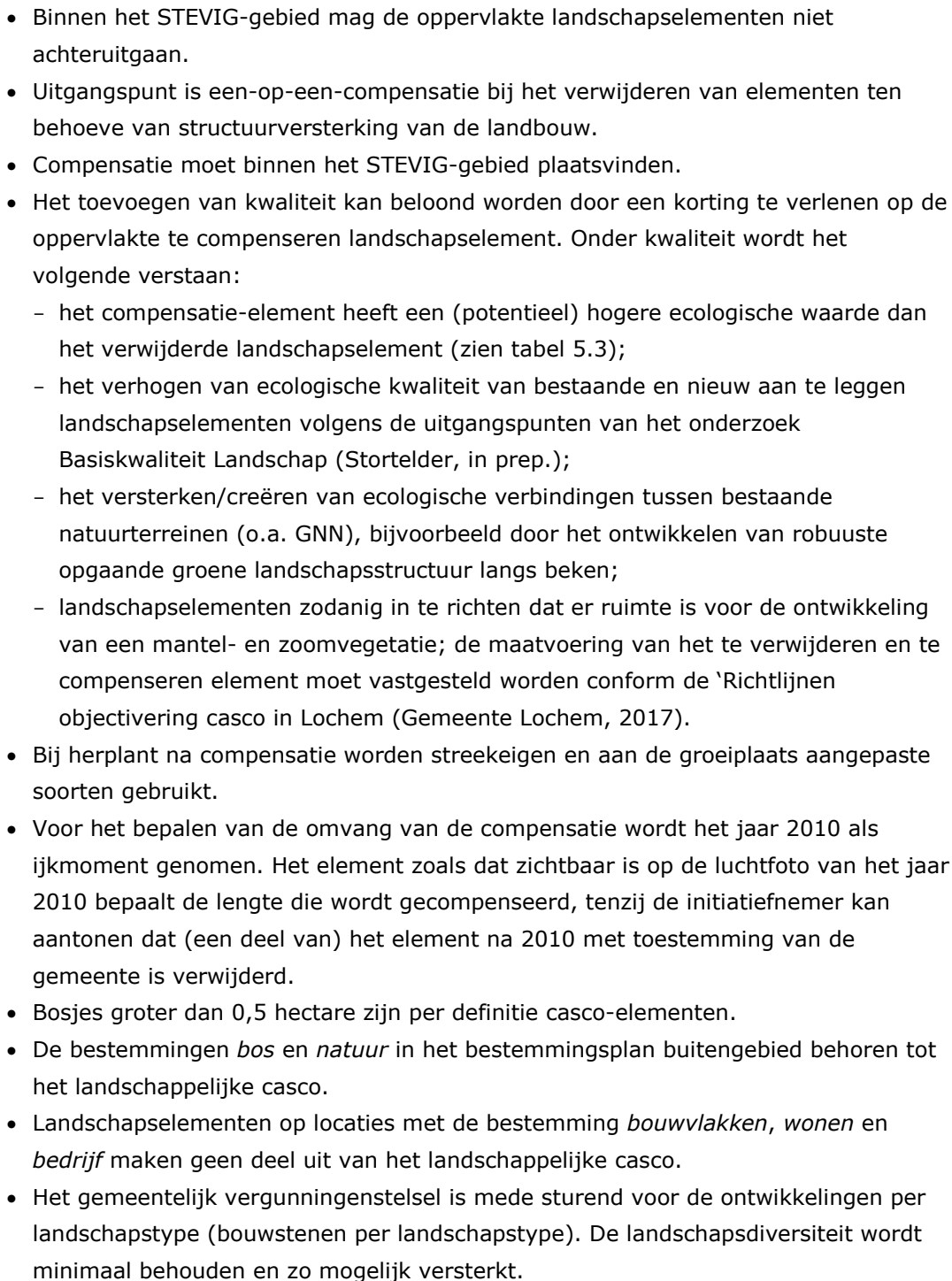 \\
\hline
\end{tabular}


- Het verplaatsen van landschapselementen van agrarische gronden naar de (Kostenneutraallaanbomenbeheer) gemeentebermen is niet mogelijk.

- Omvormen van laanbomen naar andere typen landschapselementen met een hogere ecologische kwaliteit (hakhoutsingels) wordt gezien als een van de mogelijkheden voor beide projecten. Hier zou synergie te bereiken zijn. Wegbermen zijn te smal om singels te kunnen ontwikkelen, maar een wegbegeleidende houtsingel op grond van een particulier of agrariër wordt als een kansrijk alternatief gezien.

Structuurversterking landbouw Wateropgaven (KRW, WB21)
- Vergroting van de veldkavels. Minimale kavelgrootte 2 ha, afhankelijk van landschapstype.

- Structuurverbetering door verplaatsing van landschapselementen van het midden van de percelen naar de randen.

- Ruimere toegang tot de kavels, het verbreden van doorgangen bij singels en sloten is vaak al voldoende om bewerkbaarheid te vergroten; maatvoering nader te bepalen.

- Uitruilen van landschapselementen met particulieren, bijv. in het kader van NSW landgoederen.

- Ontwikkelen/verplaatsen van opgaande groene landschapselementen (singels en houtwallen) langs/naar watergangen, mits juridisch goed geregeld.

- De steilranden in het gebied zijn kansrijke plekken om te compenseren.

- Uitgangspunt vanuit de wateropgave is dat het casco aansluit bij het watersysteem:

- ruimtelijke systemen (stroomgebieden)

- landschappelijk Casco in te richten als verbindende elementen

- landschappelijk Casco niet alleen te benaderen als een stelsel van opgaande beplantingen, maar indien relevant in samenhang met natte structuren (beken en waterlopen) en (kort) ruige oever en moerasvegetaties

- efficiënt beheer en onderhoud

- Uitgangspunt is dat cascobenadering niet gebruikt mag worden om KRW-opgaven in te vullen voor de waterlichamen met een ambitieniveau 'hoog' of 'middel'.

- Voor KRW-waterlichamen met een 'laag' ambitieniveau, Dommerbeek en (Oude) Eefsebeek (plus bovenloop) en alle niet- KRW-waterlichamen, zijn (onder voorwaarden) mogelijkheden voor de cascobenadering door de aanleg houtsingels aan de zuidkant van de watergang. Het waterschap heeft hier een model voor uitgewerkt.

Natuurbeschermingswet \& Flora- - Alle ingrepen toetsen aan NB-wet en FF-wet.

en Faunawet

Natura 2000

- Alle opgaande elementen die vallen binnen grenzen van Natura-2000-gebieden vallen onder het landschappelijke casco.

Gelders Natuurnetwerk

- Alle opgaande beplanting in het Gelders Natuurnetwerk vallen onder het

(figuur 5.1) landschappelijke casco. Bij uitzondering (kleine geïsoleerd liggende landschapselementen/groot maatschappelijke nut) kan hiervan worden afgeweken. Overleg met de provincie vereist.

- De Groene ontwikkelingszones zijn gebieden waar bij voorkeur het landschappelijke casco wordt versterkt. Daarmee wordt de connectiviteit tussen de onderdelen van het GNN vergroot.

Collectief agrarisch natuur- en

- De landschapselementen in de gebiedsaanvraag nieuwe stelsel ANLB en alle elementen met lopende contracten zijn niet vanzelfsprekend onderdeel van het landschappelijke casco. Het streven is om nieuwe gecompenseerde elementen onder deze regeling te brengen. Het afsluiten van beheersovereenkomsten is niet mogelijk buiten de begrenzing van de leefgebieden van het ANLB. 
In het STEVIG-gebied liggen twee oost-weststructuren die niet rechtstreeks gekoppeld zijn aan de agrarische ontginningsgeschiedenis van het gebied: het Twentekanaal en de spoorlijn ZutphenHengelo. De landschapselementen langs het Twentekanaal en de spoorlijn worden generiek tot het casco gerekend. De redenen daarvoor zijn de volgende:

- een deel van de elementen erlangs valt reeds in het GNN of is door de gemeente Lochem als bos of natuur bestemd;

- doorlopende en samenhangende oost-weststructuur die als ecologische verbindingszone kan fungeren;

- robuuste eigenstandige structuur in het landschap zonder directe samenhang met het aangrenzende cultuurlandschap;

- elementen spelen geen rol van betekenis in de landbouwstructuurversterking in het kader van STEVIG.

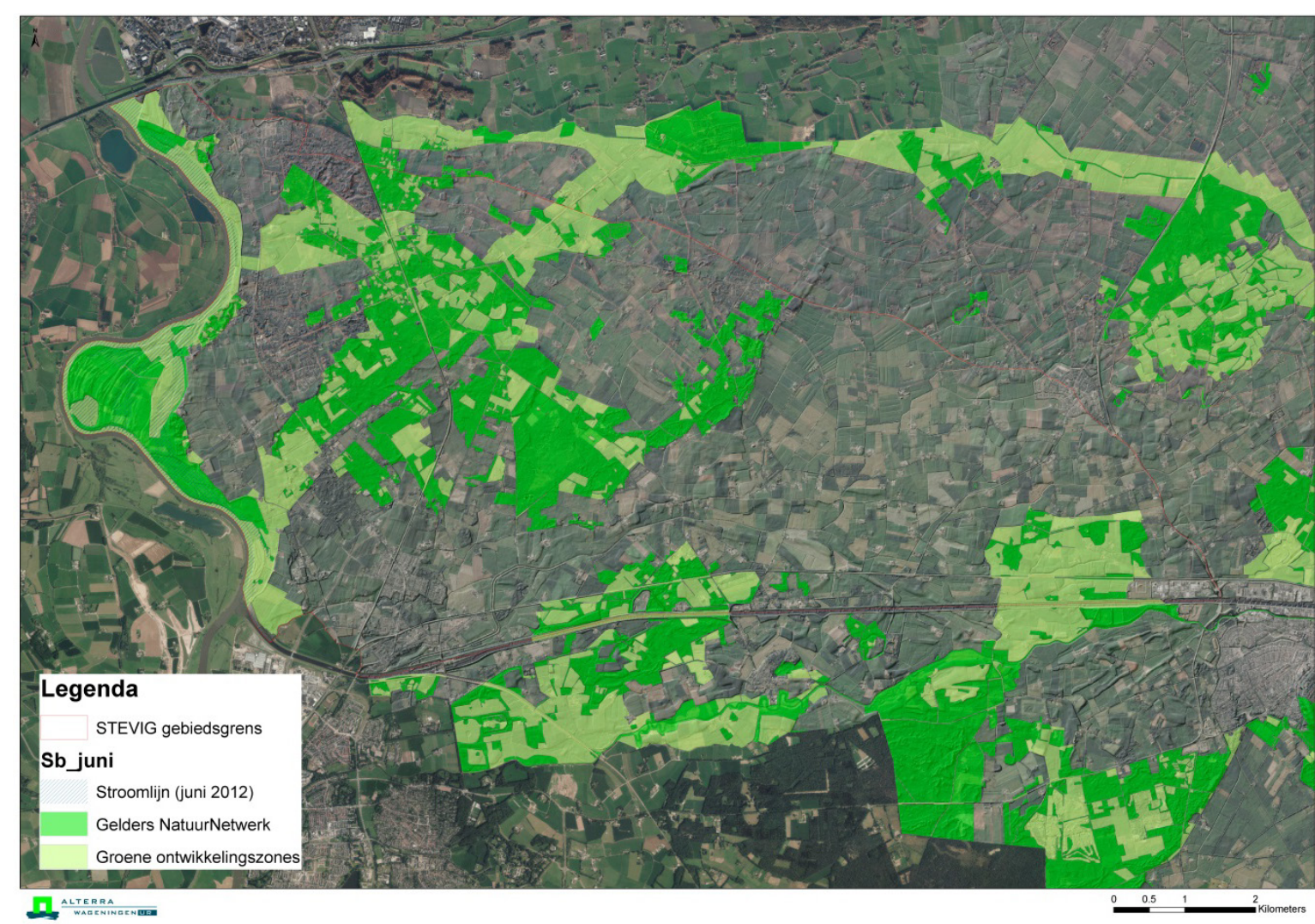

Figuur 5.1 Gelders NatuurNetwerk, de Groene ontwikkelingszones en de gebieden die binnen het Programma Stroomlijn van Rijkswaterstaat vallen in de gemeente Lochem.

\subsection{Bouwstenen per landschapstype en landschapsdynamiekklasse}

Onderstaande bouwstenen zijn afgeleid uit de beschrijving van de landschapstypen, de gesprekken met de stakeholders in het gebied en uit de toelichting van het bestemmingsplan buitengebied van de gemeente Lochem (bijlage 1). De bouwstenen variëren per landschapstype en mate van landschapsdynamiek.

De soortensamenstelling van de landschapselementen verschilt per landschapstype, maar is meer nog gekoppeld aan de groeiplaats, de combinatie van bodemtype en grondwatersituatie. In het document Richtlijnen Objectivering Cascobenadering in Lochem (Gemeente Lochem, 2017) is een lijst streekeigen boom- en struiksoorten te zien per groeiplaats, die de voorkeur heeft om aangeplant te 
worden in Lochem. In de karakterisering van de landschapstypen (hoofdstuk 4) zijn de kenmerkende bodemtypen en grondwatertrappen per landschap beschreven. Figuur 4.1 en 4.2 tonen de Bodemkaart van Nederland 1:50 000 en de Grondwatertrappen 1:50 000 kaart van het STEVIG-gebied. Nietinheemse soorten vallen niet onder de regels van het casco.

Per landschapstype en dynamiekklasse is een richtgetal voor de kavelgrootte, in dit kader gedefinieerd als de open ruimte tussen opgaande landschapselementen vastgesteld. Dit is een maat voor de schaal van het landschap dat in het kader van de cascobenadering wordt nagestreefd.

Tabel 5.2 Kavelgrootte (ha) per landschapstype en dynamiekklasse (voorstel)

\begin{tabular}{llll} 
& \multicolumn{2}{l}{ Dynamiek } & matig \\
\cline { 2 - 4 } Bandschapstypen & laag & $1-5$ & $5-10$ \\
\hline Oude broekontginning & $0,5-2$ & $2-5$ & $5-20$ \\
\hline Jonge broekontginningen & $0,5-2$ & $5-20$ & - \\
\hline Jonge bos- en heideontginningen & - & $3-10$ & $10-15$ \\
\hline Kampenlandschap & $1-3$ & $3-5$ & $5-10$ \\
\hline Essenlandschap & $1-3$ & $3-5$ & $5-10$ \\
\hline Uiterwaarden & - & $0,5-10$ & $5-15$ \\
\hline Buitendijks rivierterrassenlandschap & $0,5-10$ & $5-10$ & $5-15$ \\
\hline Rivierduinen & - & - & - \\
\hline Rivierterrassenlandschap & 0,5 & $3-10$ & $10-30$ \\
\hline Oud rivierterrassenlandschap met esdek & - & $3-10$ & $10-30$ \\
\hline
\end{tabular}

Voorafgaand aan de beschrijving van de bouwstenen per landschapstype wordt een korte visie gegeven op de landschapsontwikkeling gebaseerd op de landschapsbeschrijving en de gebiedsanalyse en worden een of meerdere suggesties gedaan om de kwaliteit van het landschap te verhogen. Dit sluit aan bij het streven van de gemeente Lochem en drie ander achterhoekse gemeenten naar een basisnatuurkwaliteit voor de landschapselementen in het buitengebied (zie notitie: Naar een benchmark voor Basiskwaliteit natuur en landschap en bijzondere natuurkwaliteit (2015)). De visie en kwaliteitsaspecten hebben vooral betrekking op de wijze van compenseren.

\subsubsection{Essenlandschap}

\section{Visie}

Essenlandschappen zijn open tot halfopen agrarische cultuurlandschappen met een landbouwkundig gebruik. Het landschapsdoel is de essen zelf open te houden en alleen verdichting van het landschap na te streven in de randen van de essen en de overgangen naar aangrenzende landschapstypen. Doorgaande wegen zijn geheel beplant of de beplanting begeleidt de wegen tot op de flanken van de es. Op het hoogste deel van de es is de weg dan onbeplant. Waar een wegbeplanting samenvalt met een landschapselement op een steilrand gaat de voorkeur uit naar een optimale ontwikkeling van het element op de steilrand. In het kader van kostenneutraal bomenbeheer kan in deze specifieke situatie de laanbeplanting vervallen.

\section{Verhogen kwaliteit}

Steilranden van essen zijn de voorkeurslocaties voor aanleg van groene elementen ter versterking van het essenlandschap. Landschapselementen beschermen de steilranden tegen verval en door de gradiënt (hoog-laag) en expositie is een landschapselement op een steilrand ecologisch waardevol. Door rekening te houden met de expositie van de steilrand bij de aanleg van landschapselementen kan de potentiële natuurkwaliteit van het element worden verhoogd. Aanbevolen wordt de meer noord georiënteerde steilranden te beplanten met struweel en opgaande hakhoutsoorten (zie figuur 5.2) en de zuid georiënteerde steilranden met struweelbeplanting, maar ook gedeeltelijk onbeplant te laten voor de ontwikkeling van kruidenrijke schraalgraslanden (zie figuur 5.3). 


\section{Hoogdynamisch: open onregelmatige blokverkaveling}

- alle bestaande opgaande groene elementen op de randen van het essencomplex zijn onderdeel van het historisch-agrarisch cultuurlandschap en maken deel uit van het casco;

- behoud/versterk afwisseling tussen de openheid van het essencomplex en de beplanting op steilranden door:

- aanleg beplanting op de steilranden van het essencomplex, op overgangen naar aangrenzende landschapstypen, met name het beekdallandschap;

- op essen/enken zelf geen aanleg van landschapselementen;

- behoud/versterken laanbeplanting langs hoofdwegen mits zicht vanaf wegen op de open essen behouden blijft; bij holle wegen gaat beplanting op de steilrand boven laanbeplanting;

- behoud reliëf van steilranden en bolle percelen;

- behoud grillige kavelstructuur (onregelmatige blokverkaveling, gebogen grenzen);

- de geomorfologie is leidend bij het versterken van de groenstructuur op de esranden, niet de bodem;

- gewenste kavelgrootte nieuwe kavels: 5-10 ha.

Matig dynamisch: halfopen onregelmatige blokverkaveling

- alle bestaande opgaande groene elementen op de randen van de individuele essen zijn onderdeel van het historisch-agrarisch cultuurlandschap en maken deel uit van het casco;

- behoud de bestaande afwisseling tussen de open essen en beplanting op steilranden en kavelgrenzen door:

- aanleg beplanting op de steilranden van het escomplex, op overgangen naar aangrenzende landschapstypen, met name het beekdallandschap;

- op essen/enken zelf geen aanleg van landschapselementen;

- behoud beplanting langs wegen; bij holle wegen gaat beplanting op de steilrand boven laanbeplanting;

- behoud zicht vanaf wegen op de open essen;

- behoud reliëf van steilranden en bolle percelen;

- behoud grillige kavelstructuur (onregelmatige blokverkaveling, gebogen grenzen);

- de geomorfologie is leidend bij het versterken van de groenstructuur op de esranden, niet de bodem;

- gewenste kavelgrootte nieuwe kavels: 3-5 ha.

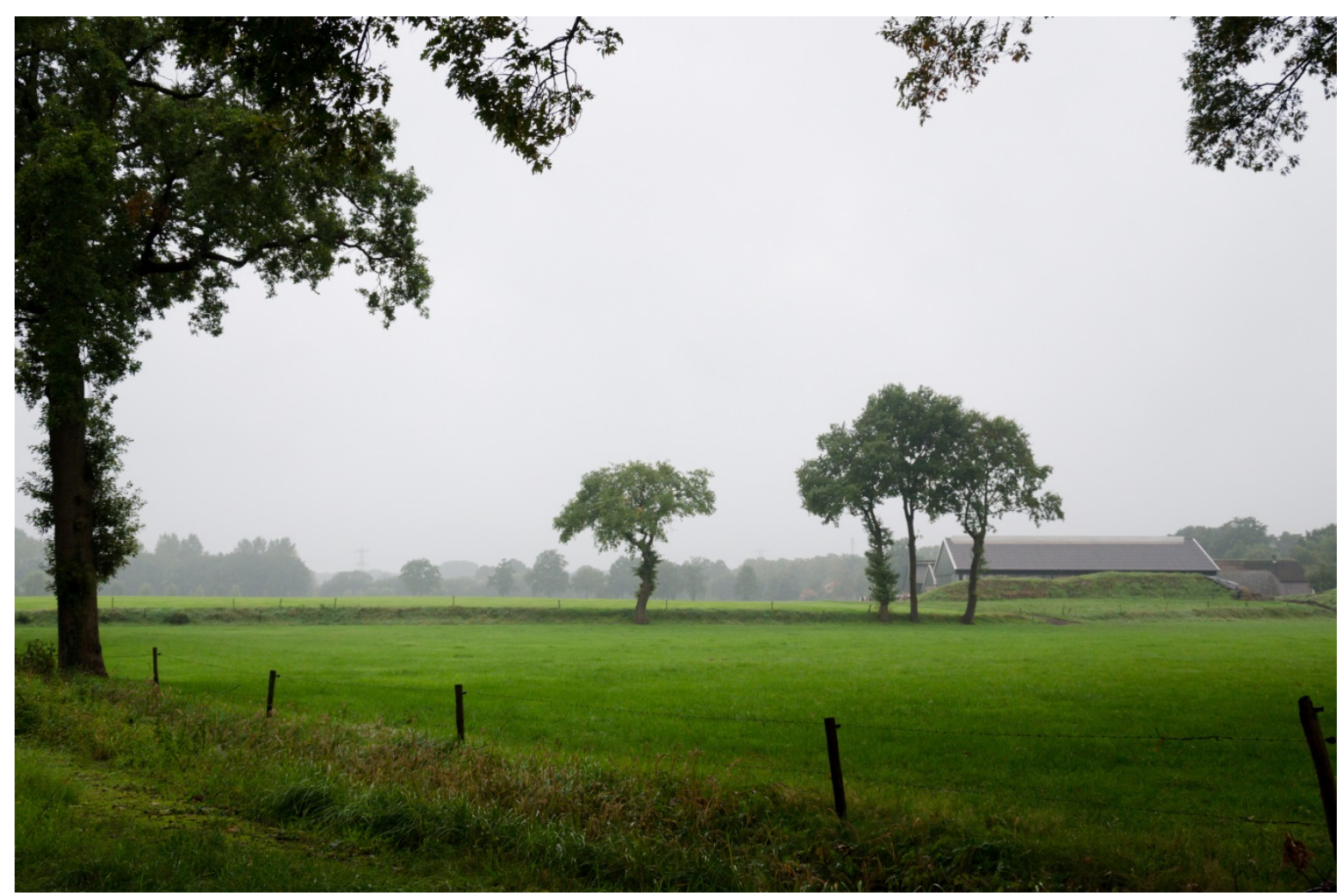

Figuur 5.2 Steilrand van een es met een schaarse beplanting van hoog opgesnoeide eiken. Een geschikte locatie voor compensatie met een gevarieerde steilrandbeplanting van struweel en hakhout. 


\subsubsection{Kampenlandschap}

\section{Visie}

Kampenlandschap met een lage dynamiek vinden we in het projectgebied terug in landgoederen zoals Joppe en Groot Dochteren. De strategie voor dit landschap is gericht op behoud van de bestaande onregelmatig blokverkaveling te midden van bospercelen en brede houtsingels, zonder het landschap verder te verdichten. In de matig en hoogdynamische kampenlandschappen wordt een ontwikkeling ingezet gericht op het ontwikkelen van een samenhangende landschapsstructuur, in samenhang met de naastgelegen beekdalen. Daarbij ligt de focus op het plaatsen van landschapselementen op steilranden grenzend aan de beekdalen.

\section{Verhogen kwaliteit}

Steilranden zijn voorkeurslocaties voor aanleg van groene elementen ter versterking van het kampenlandschap. Landschapselementen beschermen de steilranden tegen verval en door de gradiënt (hoog-laag) en expositie is een landschapselement op een steilrand ecologisch waardevol. Door rekening te houden met de expositie van de steilrand bij de aanleg van landschapselementen kan de potentiële natuurkwaliteit van het element worden verhoogd. Aanbevolen wordt de meer noord georiënteerde steilranden te beplanten met struweel en opgaande hakhoutsoorten en de zuid georiënteerde steilranden met struweelbeplanting, maar ook gedeeltelijk onbeplant te laten voor de ontwikkeling van kruidenrijke schraalgraslanden.

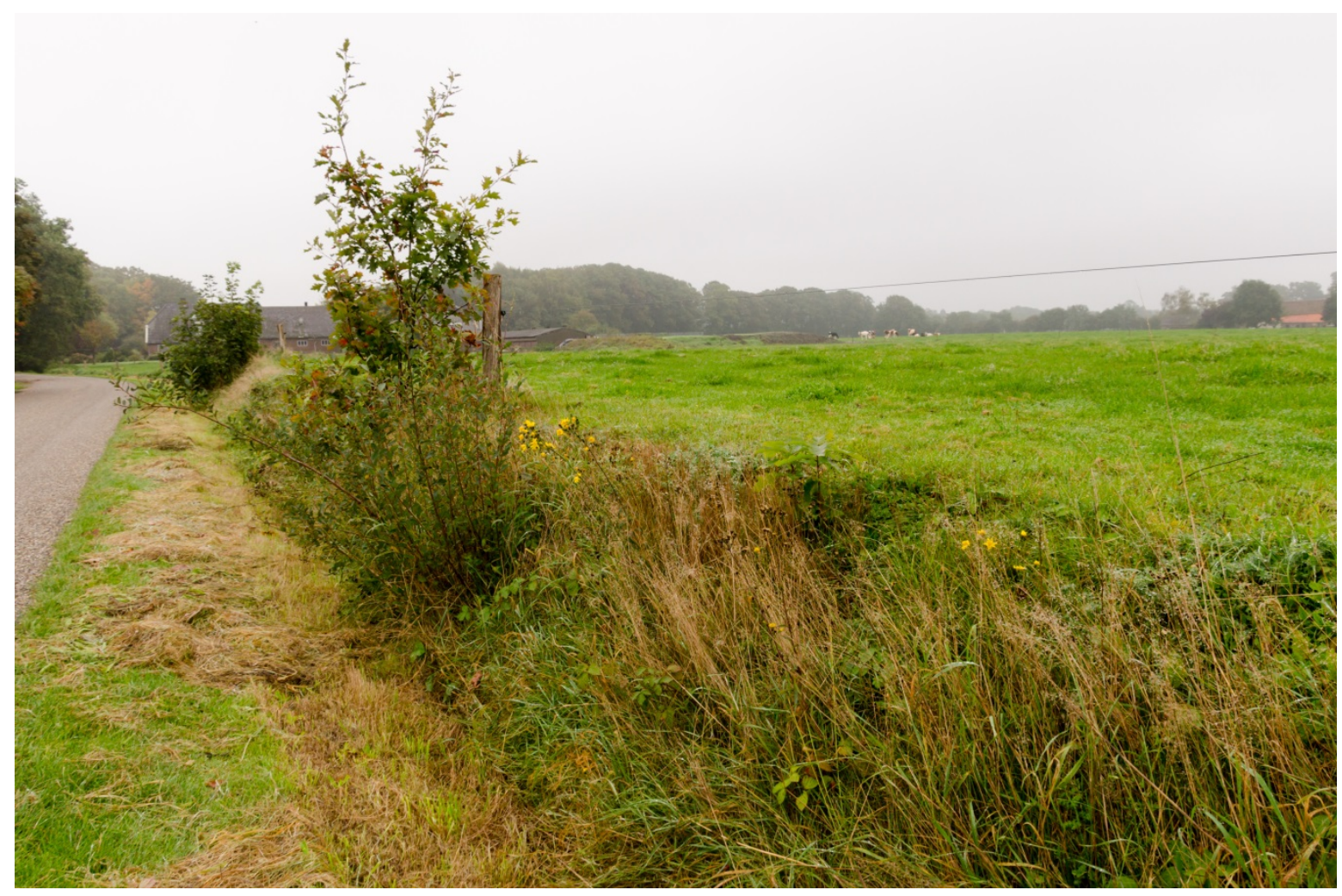

Figuur 5.3 Spontane struweelvorming en vestiging van plantensoorten van schrale graslanden op een steilrand van een kamp. Landschapselementen met een hoge ecologische waarde. Niet alle steilranden hoeven beplant te worden.

Hoogdynamisch: open (onregelmatige) blokverkaveling

- gave (dimensie en kwaliteit) bestaande groene elementen in de hoofdstructuur vormen het casco;

- versterken wegbeplanting als onderdeel van de hoofdstructuur;

- oorspronkelijke kleinschalige structuur wordt vervangen door nieuwe structuur:

- een grootschalige onregelmatige blokverkaveling aansluitend op de gave onderdelen van de hoofdstructuur; 
- nieuwe landschapselementen worden gekoppeld aan de structuur van beeklopen en grotere watergangen ter versterking van de ecologische samenhang van het landschap (Model WRIJ);

- nieuwe elementen niet alleen lijnvormig, maar ook in de vorm van kleine hakhoutbosjes < 0,5 ha;

- opgaande groene elementen niet zijnde het casco kunnen gebruikt worden om de nieuwe hoofdstructuur te versterken volgens de richtlijnen van het compensatiebeginsel;

- behoud steilranden \& microreliëf kampen;

- gewenste kavelgrootte nieuwe kavels: 5-10 ha.

Matig dynamisch: halfopen onregelmatige blokverkaveling

- alle bestaande opgaande groene elementen in de hoofdstructuur vormen het casco van het kampenlandschap;

- opgaande groene elementen in de secundaire structuur kunnen gebruikt worden om de hoofdstructuur te versterken volgens de richtlijnen van het compensatiebeginsel;

- eenmansessen en -kampen worden opengehouden; de randen versterken en daarbij aansluiten op de geomorfologie;

- behoud steilranden \& microreliëf kampen

- beplanting langs wegen;

- behoud grillige structuur van onregelmatige verkaveling \& gebogen grenzen

- gewenste kavelgrootte nieuwe kavels: 3-5 ha.

Laag dynamisch: besloten onregelmatige blokverkaveling

- alle bestaande opgaande groene elementen in zowel de hoofdstructuur als de secundaire structuur zijn onderdeel van het agrarisch cultuurlandschap en vormen het casco van het kampenlandschap;

- kleinschalige secundaire structuur van singels, houtwallen en hagen wordt (waar nodig)versterkt;

- eenmansessen en -kampen worden opengehouden; de randen versterken en daarbij aansluiten op de geomorfologie;

- behoud steilranden \& microreliëf kampen

- beplanting langs wegen;

- behoud grillige structuur van onregelmatige verkaveling \& gebogen grenzen

- gewenste kavelgrootte nieuwe kavels: 1-3 ha.

\subsubsection{Beekdallandschap}

\section{Visie}

Het beekdallandschap is een van de landschappen in het STEVIG-gebied waar sinds de jaren zestig van de vorige eeuw grote veranderingen hebben plaatsgevonden (zie figuur 5.4). Verbetering van de landbouwwaterhuishouding hebben ertoe geleid dat in het merendeel van de beekdalen de relatief kleinschalige blokverkaveling met sloten en beplanting is vervangen door grote aaneengesloten kavels. Verspreid in het beekdal komen opgaande landschapselementen voor.

De beken en beekdalen kunnen de verbindende schakel gaan vormen tussen de natuur en landgoederenzone ten oosten van het STEVIG-gebied (Verwolde en Ampsen) met de onderdelen van het Gelders Natuurnetwerk (GNN) in het westelijke deel van het STEVIG-gebied. De cascobenadering streeft ernaar een oost-west gerichte samenhangende structuur te ontwikkelen van landschapselementen, afwisselend langs de zuidoever van de beek en de noord georiënteerde steilranden op de grens van het beekdal met de aangrenzende landschappen.

\section{Verhogen kwaliteit}

De kwaliteit van landschapselementen langs de beek kan geoptimaliseerd worden door het model WRIJ (zie H 3.4) toe te passen. Optimaal is als aan de zuidoever van de beek ter plaatse van het onderhoudspad een geleidelijke nat-drooggradiënt wordt aangelegd die met struweel en haksoorten wordt beplant. Op de noordoever van de beek wordt het bestaande, verbrede onderhoud pad beheerd als spuit- en bemestingsvrije zone. Hier kunnen structuurrijke botanische graslanden tot ontwikkeling komen. Gronden in eigendom van het Waterschap en in gebruik door agrariërs als botanisch grasland kunnen worden meegenomen in de mestplaatsingsruimte. 


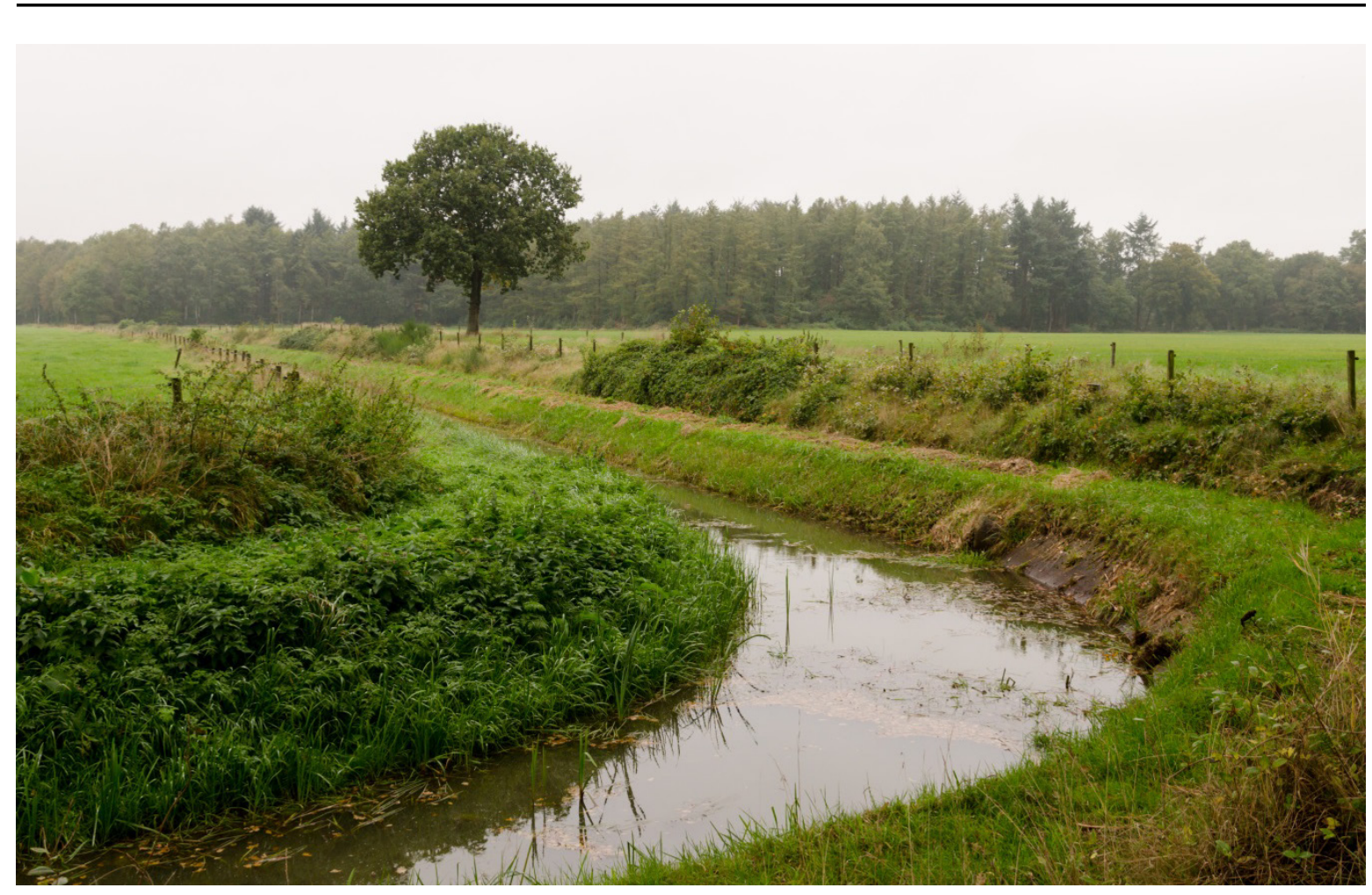

Figuur 5.4 Genormaliseerde beek in een hoogdynamisch beekdal landschap met dubbelzijdig onderhoudspad.

Hoogdynamisch: halfopen tot open onregelmatige blokverkaveling

- bestaande groene elementen in de hoofdstructuur (beekloop, kruisende wegen en beekdalranden) vormen het casco;

- oorspronkelijke secundaire structuur wordt omgevormd tot versterkte hoofdstructuur door:

- nieuwe landschapselementen te koppelen aan de structuur van beeklopen en grotere watergangen ter versterking van de ecologische samenhang van het landschap (Model WRIJ);

- beekdalranden met beplanting te versterken;

- oriëntatie nieuwe beplanting in het beekdal:

- oost-west parallel aan de beek: hoog opgaand

- haaks op de beekloop: laag, met uit zondering van kruisende wegen hoog

- opgaande groene elementen niet zijnde het casco kunnen gebruikt worden om de nieuwe hoofdstructuur te versterken volgens de richtlijnen van het compensatiebeginsel;

- geen aanleg van bos > 0,5 ha in verband met behoud (half)open karakter;

- gewenste kavelgrootte nieuwe kavels 5- 10 ha; kavels mogen niet kleiner worden dan 2 ha.

\section{Matig dynamisch: halfopen tot open onregelmatige blokverkaveling}

- bestaande opgaande groene elementen in de hoofdstructuur (beekloop, kruisende wegen en beekdalranden) en gave elementen in de secundaire structuur vormen het casco van het beekdallandschap;

- niet gave opgaande groene elementen in de secundaire structuur kunnen gebruikt worden om de hoofdstructuur en secundaire structuur te versterken volgens de richtlijnen van het compensatiebeginsel;

- behoud steilranden en microreliëf;

- behoud grillige structuur van onregelmatige verkaveling \& gebogen grenzen;

- gewenste kavelgrootte nieuwe kavels maximaal 5 ha; kavels mogen niet kleiner worden dan 1 ha.

\section{Laagdynamisch: kleinschalige onregelmatige blokverkaveling}

- alle bestaande opgaande groene elementen in zowel de hoofdstructuur als de secundaire structuur zijn onderdeel van het agrarische cultuurlandschap en vormen het casco van het beekdallandschap;

- kleinschalige secundaire structuur van singels, houtwallen, en hakhout/broekbosjes wordt (waar nodig) versterkt;

- behoud steilranden en microreliëf; 
- behoud grillige structuur van onregelmatige verkaveling en gebogen grenzen;

- kavelgrootte minimaal gelijk houden, waar mogelijk verkleinen tot minimaal ca. 0,5 ha.

\subsubsection{Jonge Broekontginning}

\section{Visie}

Het open broekontginningen-landschap kent een aantal duidelijke nno-zzw-georiënteerde parallelle lijnen waarlangs het landschap ontgonnen en ontsloten is. De beplanting langs deze weg- en waterloopstructuren vormen de dragers van het landschap, het landschappelijke casco (zie figuur 5.5). De visie op het Jonge broekontginningen-landschap is deze cascolijnen waar nodig te versterken. In de richting van de ontginningsassen behoudt het landschap zijn openheid. Dwars op deze structuur is het landschap meer gesloten van aard. Karakteristiek voor het Emsbroek is een aantal geïsoleerde moerasbosjes verspreid over het gebied. Deze bosjes worden al meer met elkaar verbonden door versterking van de nno-zzw-structuur van landschapselementen, maar door de aanleg van landschapselementen langs een watergang haaks op de hoofdstructuur komt een sluitend netwerk tot stand.

\section{Verhogen kwaliteit}

De kwaliteit van landschap en ecologie wordt verhoogd door de versterking van het landschappelijke netwerk en de aanleg van landschapselementen volgens het model WRIJ. Het plaatsen van een landschapselement op de zuidoever van de waterloop (zonder schouwpad tussen het landschapselement en de waterloop) leidt tot een verbetering van waterkwaliteit door de schaduwwerking en het ontstaan een ecologische gradiëntzone.

\section{Matig dynamisch: open regelmatige blokverkaveling}

- parallelle ontginningsassen met daartussen een grootschalige regelmatige blokverkaveling vormen de hoofdstructuur van het landschap;

- opgaande groene elementen langs natte en droge infrastructuur (wegen en hoofdwaterlopen) en vrijstaande bossen vormen het casco van het landschap;

- behoud open karakter;

- noodnoordoost-zuidzuidwest-structuur van het landschap versterken volgens compensatiebeginsel:

- bestaande opgaande groene elementen langs wegen en waterlopen

- nieuwe elementen langs hoofdwaterlopen

- ecologische verbindingen (ruigtes) langs waterlopen tussen vrijstaande bossen;

- gewenste kavelgrootte nieuwe kavels: 5-20 ha.

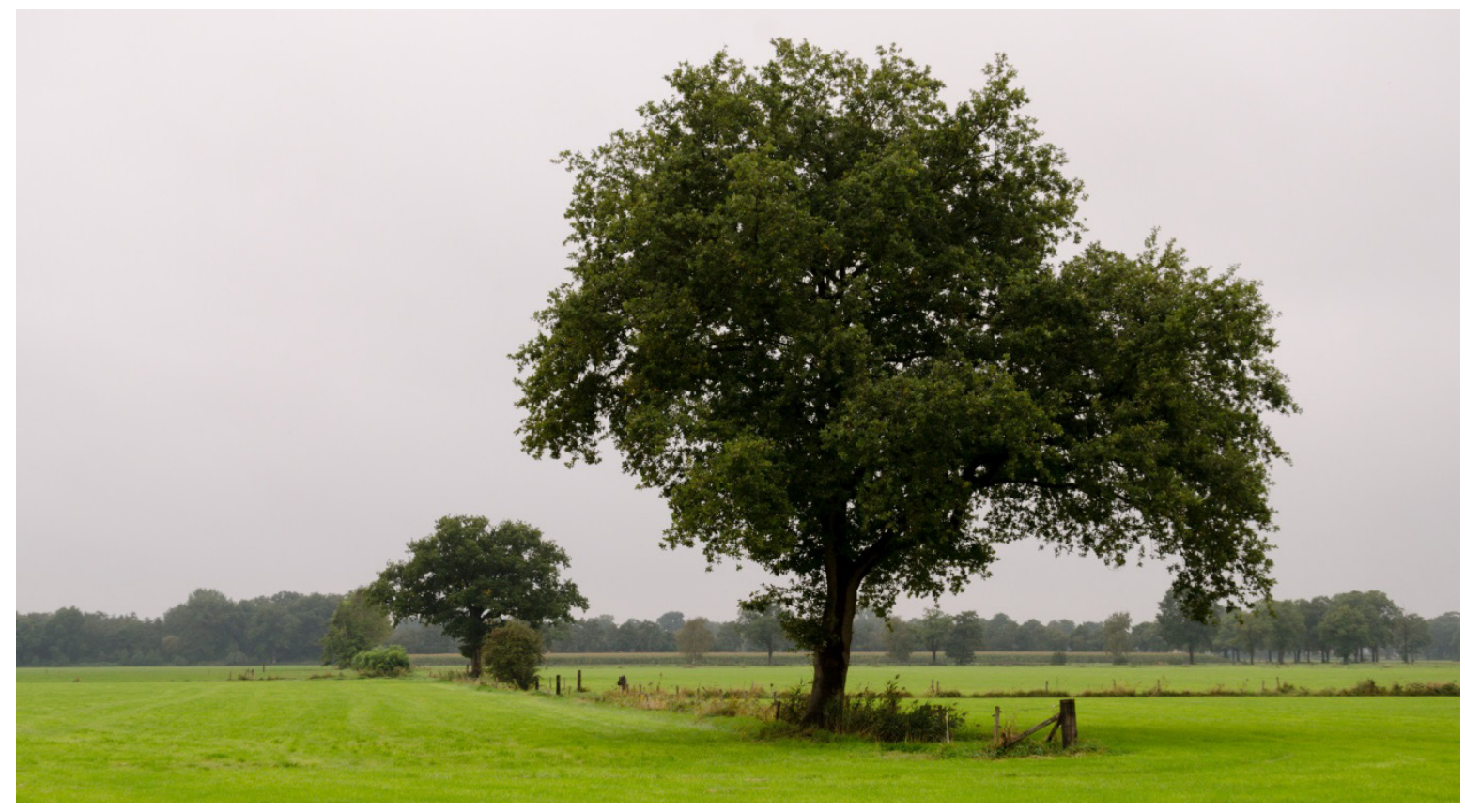

Figuur 5.5 Hoofdstructuurelementen in de jonge broekontginningen die versterkt kunnen worden door compensatie. 


\subsubsection{Oude broekontginningen}

\section{Visie}

Oorspronkelijke landschap met een kleinschalige blokontginning op de overgang van de hoger gronden naar de beekdalen. Dit landschap heeft sterke veranderingen ondergaan. Het is opener geworden met een grootschalige blokverkaveling waarin verspreid landschapselementen voorkomen, dikwijls dwars op de lengterichting van de beekdalen georiënteerd.

In gebieden met lage dynamiek behouden we de kleinschalige landschapsstructuur en versterken we deze door deze in te passen in het netwerk van omringende landschap. In gebieden met een matige dynamiek streven naar het creëren van enkele samenhangende landschapsstructuren dwars op het beekdal. In de hoogdynamische gebieden zetten we de resterende landschapselementen in om nieuwe landschapsstructuren langs de beken te kunnen ontwikkelen.

\section{Verhogen kwaliteit}

Koppeling van groene landschapselementen met waterlopen, poelen en moeraszones. Soortenkeuze aangepast aan de natte/vochtige groeiplaatsen in dit landschapstype.

Hoogdynamische: open regelmatige blokverkaveling

- grootschalige blokverkaveling vormt de hoofdstructuur;

- opgaande groene elementen langs natte en droge infrastructuur (wegen en hoofdwaterlopen) vormen het casco van het landschap;

- oorspronkelijke kleinschalige structuur wordt vervangen door nieuwe structuur:

- nieuwe landschapselementen worden gekoppeld aan de structuur van beeklopen en grotere watergangen ter versterking van de ecologische samenhang van het landschap (Model WRIJ);

- gewenste kavelgrootte nieuwe kavels: 5-20 ha.

Laagdynamisch: kleinschalige onregelmatige blokverkaveling

- alle bestaande opgaande groene elementen in zowel de hoofdstructuur als de secundaire structuur zijn onderdeel van het agrarische cultuurlandschap en vormen het casco van het beekdallandschap;

- kleinschalige secundaire structuur van singels, houtwallen, en hakhout/broekbosjes wordt (waar nodig) versterkt;

- kavelgrootte minimaal gelijk houden, waar mogelijk verkleinen tot minimaal ca. 0,5 ha.

\subsubsection{Jonge bos- en heideontginningslandschap}

\section{Visie}

In vergelijking met andere bos- en heideontginningslandschappen in Oost-Nederland is dit landschapstype in het projectgebied vrijwel overal vrij gesloten van karakter (met uitzondering van de omgeving Laren). De verkaveling is regelmatig en blokvormig en varieert sterk in grootte. De kavels worden omgeven door bospercelen en brede bossingels die deel uitmaken van het GNN en/of de bestemming bos of natuur hebben in het bestemmingsplan. Lange rechte wegen met een dubbele wegbeplanting doorsnijden het gebied. De structuur van opgaande landschapselementen is robuust. Voor de hoog en matig dynamische landschappen wordt ingezet op behoud en versterking van de hoofdstructuur, dat wil zeggen dat het netwerk van landschapselementen tussen de bosgebieden niet wordt aangetast en waar nodig gaten worden opgevuld. Bij het laag dynamische jonge bos- en heideontginningslandschap wordt gestreefd naar het behoud van de kleinschalige open kavels binnen het boslandschap zonder dat verdere versnippering plaatsvindt.

\section{Verhogen kwaliteit}

Creëren van gradiënten tussen bossen en open ruimtes voor de ontwikkeling van mantel- en zoomvegetaties.

Hoogdynamisch: halfopen landschap met regelmatige blokverkaveling

- opgaande groene elementen langs infrastructuur en kavelblokgrenzen en kleine bosrestanten vormen het casco van het landschap; 
- beplanting die geen onderdeel is van het casco kan worden ingezet ter versterking van de hoofdstructuur van het landschap langs infrastructuur en kavelblokgrenzen, wegen en waterlopen, in het bijzonder de lanen met dubbele bomenrijen;

- gewenste kavelgrootte nieuwe kavels: 10-15 ha.

Matig dynamisch: halfopen tot gesloten landschap met regelmatige blokverkaveling

- bospercelen in een netwerk van opgaande groene elementen langs infrastructuur en kavelgrenzen vormen het casco van het landschap;

- beplanting die geen onderdeel is van het casco kan worden ingezet ter versterking van de hoofdstructuur langs wegen en waterlopen, en kavelgrenzen, in het bijzonder de lanen met dubbele bomenrijen;

- gewenste kavelgrootte nieuwe kavels: 3-10 ha.

Laagdynamisch: gesloten bos landschap met regelmatig blokverkaveling en halfopen heideterreinen

- alle bospercelen en heideterreinen in een netwerk van opgaande groene elementen langs infrastructuur en kavelgrenzen vormen het casco van het landschap;

- hoofdstructuur en kleinschalige secundaire structuur van singels, houtwallen en hagen worden versterkt;

- gewenste kavelgrootte nieuwe kavels: 1-3 ha.

\subsubsection{Uiterwaarden}

\section{Visie}

In de uiterwaarden wordt de cascobenadering voor het landschap gedomineerd door het heersende ruimtelijk beleid. Het buitendijkse rivierengebied langs de IJssel valt onder de Vogel- en Habitatrichtlijn (N2000), een groot gedeelte valt binnen het GNN en een aanzienlijk deel van de landschapselementen valt binnen de bestemming natuur volgens het bestemmingsplan. Op grond van genoemde beleidskaders worden alle opgaande groene landschapselementen in de uiterwaarden als landschappelijk casco aangeduid. Echter, in de uiterwaarden is ook het Programma Stroomlijn van kracht, gericht op het behouden van voldoende doorstroomcapaciteit in het rivierengebied voor een veilige afvoer tijdens hoogwaterpieken. In het kader van Stroomlijn wordt in zones waar de rivierafvoer zich concentreert de vegetatie die tot opstuwing van de waterstand kan leiden, verwijderd. Dit geldt met name voor opgaande landschapselementen met een dichte structuur, zoals de struweelhagen in het rivierheggenlandschap die haaks op de stroming zijn georiënteerd. Knotwilgenrijen in de natuurlijke laagten in de stroomrichting van de rivier stuwen minder op. Tot het landschappelijk casco in de uiterwaarden rekenen we alle elementen in de uiterwaarden, met uitzondering van landschapselementen (haaks op de rivier) die binnen de contouren van het Programma Stroomlijn vallen (figuur 5.7). Voor deze elementen worden in delen van de uiterwaarden die buiten programma Stroomlijn vallen binnen het Gelders Natuurnetwerk compensatielocaties aangegeven.

\section{Verhogen kwaliteit}

Struweelhagen met zoomvegetatie op de hogere delen van de uiterwaard (ruim uitgerasterd); knotwilgen/essen met moerasruigte in de geulvormige laagten in de stroomrichting van de rivier. Kleinschalige ooibosontwikkeling langs strangen en kolken. Figuur 5.6 laat een struweelhaag zien zoals die nu voorkomt in het gebied. 


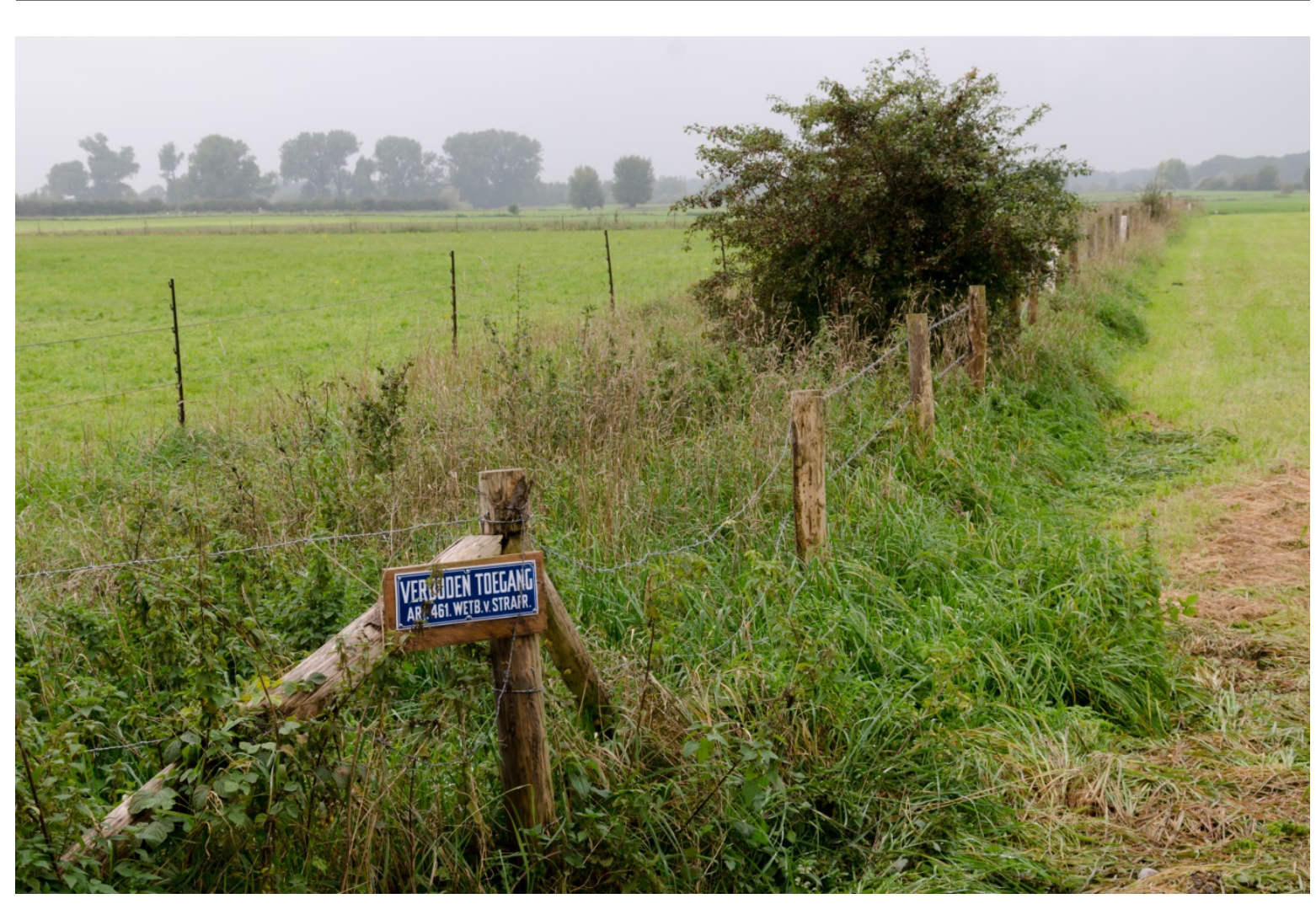

Figuur 5.6 Uitgerasterde stroken in de uiterwaarden waar struweelhagen zich kunnen ontwikkelen.

Hoogdynamisch: open landschap met een onregelmatige blokverkaveling die samenhangt met het natuurlijke reliëf.

- alle landschapselementen buiten de contouren van Programma Stroomlijn vormen het casco;

- struweelhagen langs opstrekkende verkaveling buiten de contouren van Programma Stroomlijn versterken;

- structuur van knotbomen en moerasruigten in laagten met een oriëntatie in de stroomrichting van de rivier versterken;

- gewenste kavelgrootte nieuwe kavels 5-15 ha.

Matig dynamisch: halfopen landschap met opstrekkende verkaveling, gescheiden door struweelhagen (rivierheggenlandschap).

- alle landschapselementen buiten de contouren van Programma Stroomlijn vormen het casco;

- struweelhagen langs opstrekkende verkaveling buiten de contouren van Programma Stroomlijn versterken;

- structuur van knotbomen en moerasruigten in laagten met een oriëntatie in de stroomrichting van de rivier versterken;

- gewenste kavelgrootte nieuwe kavels 0,5-10 ha.

Laagdynamisch: open landschap met een onregelmatige door het natuurlijk reliëf bepaalde verkaveling.

- alle bestaande landschapselementen buiten de contouren van Programma Stroomlijn vormen het landschappelijke casco;

- struweelhagen langs opstrekkende verkaveling buiten de contouren van Programma Stroomlijn versterken;

- structuur van knotbomen en moerasruigten in laagten met een oriëntatie in de stroomrichting van de rivier versterken;

- gewenste kavelgrootte nieuwe kavels 0,5-10 ha. 


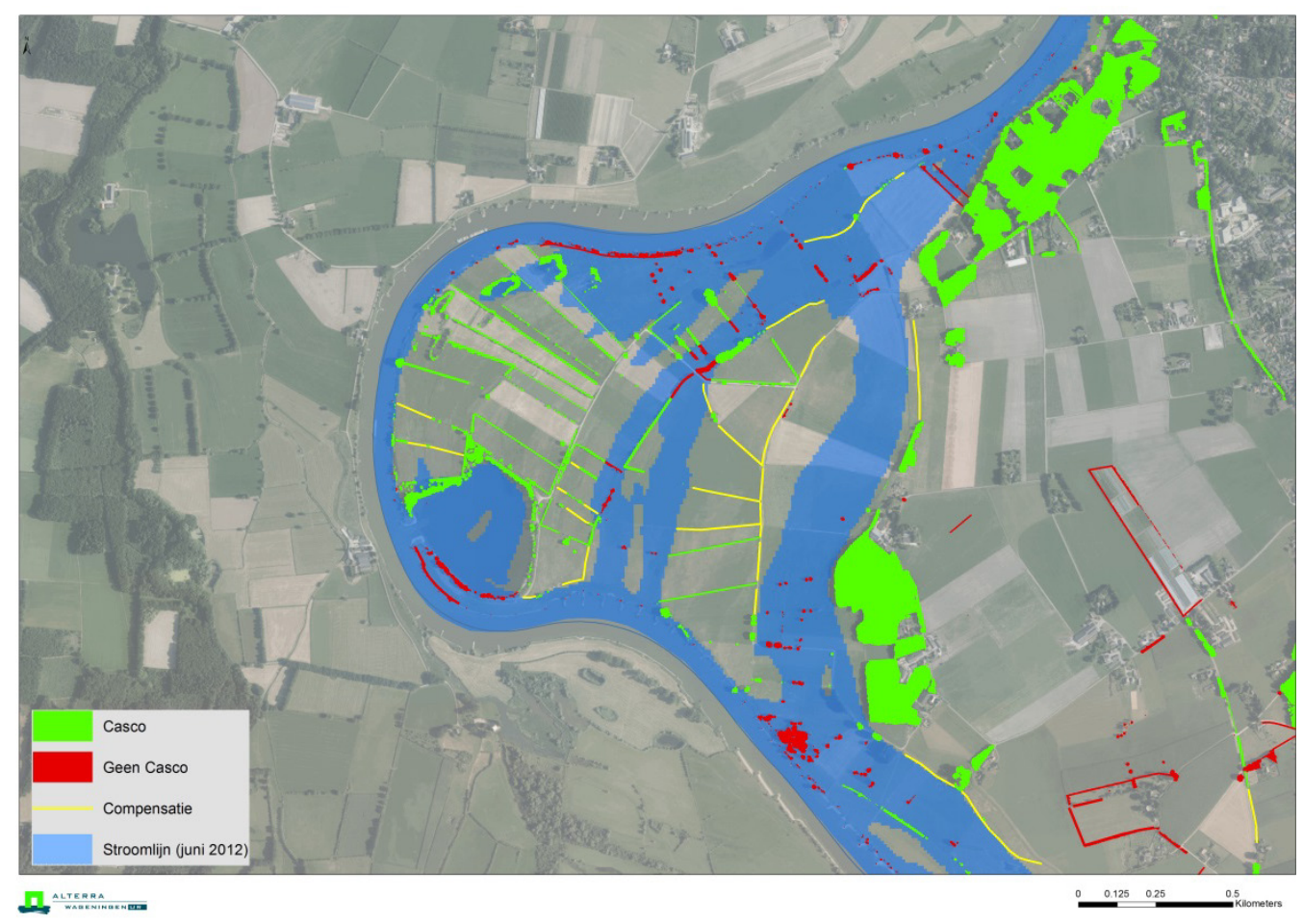

Figuur 5.7 Casco-uitwerking voor het uiterwaardenlandschap, rekening houdend met de stroombaan van het Programma Stroomlijn.

\subsubsection{Rivierduinen}

\section{Visie}

De rivierduinen liggen op de overgang van het uiterwaardenlandschap naar het binnendijkse rivierterrassenlandschap. De rivierduinen in het STEVIG-gebied zijn, op enkele kleine graslandpercelen na, vrijwel geheel met loofbos begroeid. De graslandjes zijn groeves waar in het verleden op kleine schaal zand is gewonnen. De rivierduinen vallen onder de habitatrichtlijn, zijn onderdeel van het GNN en zijn ook via het bestemmingsplan beschermd. De rivierduinbossen maken daarom ook integraal deel uit van het landschappelijke casco. De overgang van het rivierduin naar de uiterwaarden is ecologisch waardevol. Bij hoogwater op de rivier inunderen de flanken van het rivierduin en worden de zandgronden van het duin overspoeld met kalkhoudend rivierwater. Met name op de zuidelijk georiënteerde flanken van het duin ontstaan daardoor geschikte locaties voor bijzondere stroomdalflora. Dit geldt ook voor de laaggelegen graslanden in het rivierduin.

\section{Verhogen kwaliteit}

Met het plaatsen van een raster op de hellingvoet van het duin enkele meters buiten de bosrand wordt ruimte gegeven aan de ontwikkeling van een mantel- en zoomvegetatie (figuur 5.8). De geïsoleerde rivierduincomplexen via een open structuur van struweelhagen op de terrasrand opnemen in een netwerkstructuur.

Laagdynamisch: gesloten landschap zonder agrarische verkavelingsstructuur.

- alle landschapselementen vallen onder het landschappelijke casco;

- versterken van het ecologisch netwerk tussen de rivierduincomplexen onderling en de schakel tussen riviergebied en achterland door ontwikkeling van struweelhagen en zoomvegetaties op terrasranden;

- open houden van kleine graslandpercelen in de flanken van het duinen; ruimte maken voor de ontwikkeling van mantel- en zoomvegetaties;

- geen ontwikkeling van nieuwe kavels; bestaande open ruimten behouden; kavelgrootte ca. 0,5 ha. 


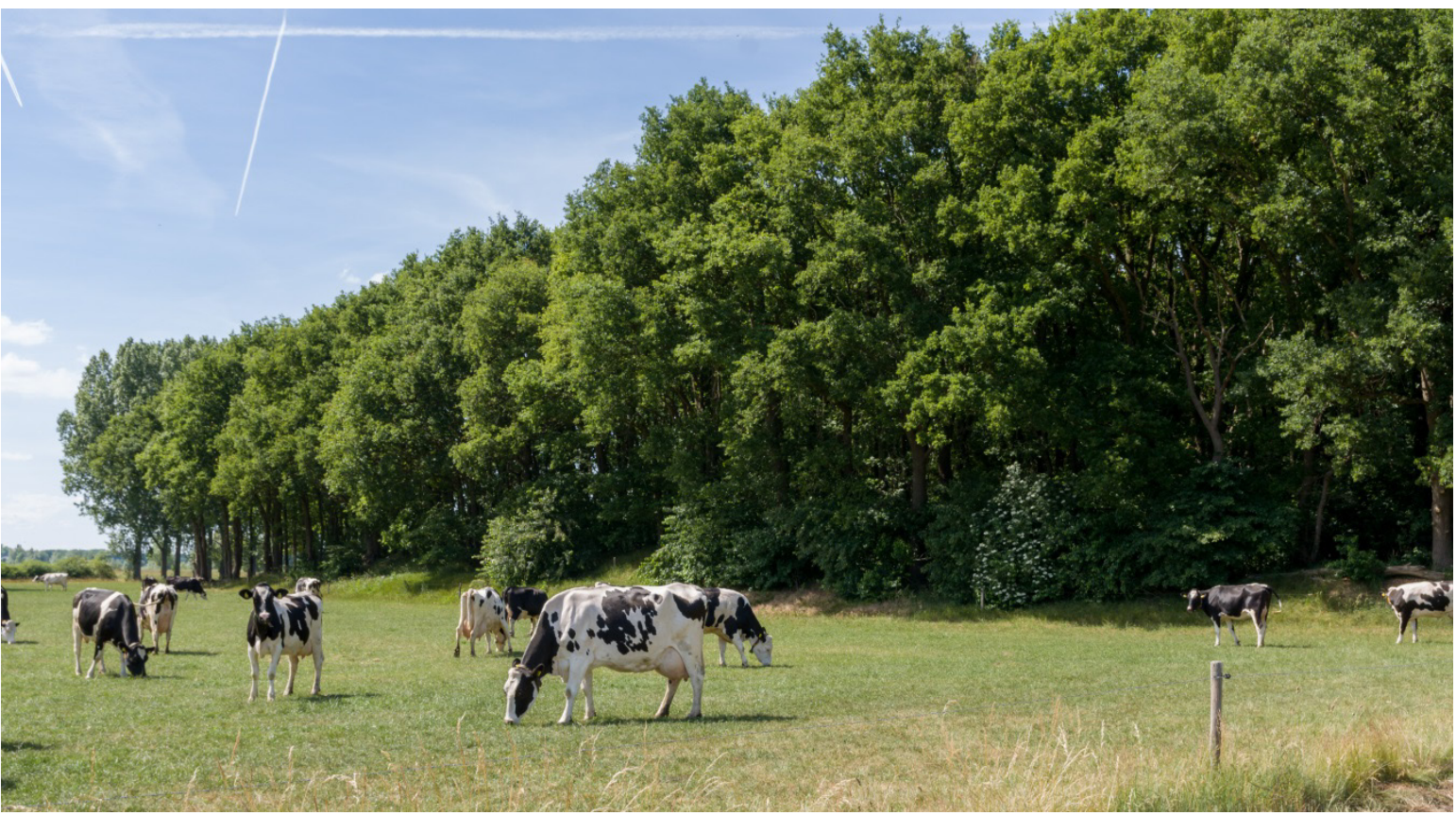

Figuur 5.8 Overgang van beboste rivierduinen naar de uiterwaarden. Unieke locatie voor de ontwikkeling van een mantel- en zoomvegetatie met stroomdalsoorten.

\subsubsection{Rivierterrassenlandschap}

\section{Visie}

Lager gelegen, vochtiger deel van het rivierterras, met in vergelijking met het terrassenlandschap met esdek van oorsprong een kleinschaliger verkaveling met meer opgaande landschapselementen en bosrestanten. Vormt een schakel tussen GNN Gorsselsche heide en de riviernatuur in de uiterwaarden. Om die reden de bestaande landschapsstructuur behouden en waar nodig netwerkkarakter versterken. Voor het buitendijkse deel van dit landschap geldt dat de terrasrand op de overgang naar het uiterwaardenlandschap kansrijk is voor de ontwikkeling van struweelhagen buiten de invloedssfeer van het Programma Stroomlijn.

\section{Verhogen kwaliteit}

Netwerk versterken; ontwikkelen van struweelhagen op de terrasrand, de overgang naar de lager gelegen uiterwaarden.

Hoogdynamisch: open onregelmatige blokverkaveling

- alle bestaande beplanting langs doorgaande wegen maakt deel uit van het casco;

- compensatie van landschapselementen op de terrasranden;

- gewenste kavelgrootte kavels open terrascomplex 10-30 ha.

\section{Matig dynamisch: halfopen onregelmatige blokverkaveling}

- alle bestaande opgaande groene elementen erfbosjes (>0,5 ha.) singels, en beplanting langs doorgaande wegen maken deel uit van het casco;

- geschoren hagen op erfgrenzen en perceelranden rekenen we niet tot het casco;

- compensatie kan plaatsvinden overal binnen het rivierterrassenlandschap maar bij voorkeur op een compensatielijn zoals bijvoorbeeld op de terrasranden of in de uiterwaarden;

- gewenste kavelgrootte kavels open terrascomplex 3-10 ha.

\subsubsection{Oud rivierterrassenlandschap met esdek}

\section{Visie}

Open akkercomplex met agrarische bedrijven en erven, vooral aan de randen van het gebied. In dit landschap zijn het voornamelijk de erfbeplanting, boomgaarden en geschoren hagen of struweelhagen 
om het erf of om individuele percelen die de groene structuur van het landschap kenmerken. Hoewel deze elementen waardevol zijn voor het landschapsbeeld, rekenen we deze elementen om twee reden niet tot het casco:

1. erfbeplanting valt in alle landschappen buiten de cascobenadering;

2. de structuur van geschoren struweel hagen is geen statische structuur, maar verandert mee met de eigendomsveranderingen.

Dit is kenmerkend voor de landschapsdynamiek die op een es thuishoort. Tevens zijn dit landschapselementen die relatief snel ontwikkeld kunnen worden. In het gebied komen daarnaast wat grotere erfbosjes en enkele robuuste singels voor die samenhang vertonen met het naastgelegen rivierduin en beplanting langs doorgaande wegen; deze landschapselementen reken we wel tot het casco. Op hoeken van percelen treffen we ook solitaire bomen aan die kenmerkend zijn voor het rivierenlandschap (populieren, walnoten en essen). Op solitaire bomen zijn de casco-regels niet van toepassing. Zij vallen onder de reguliere kapverordening. Verschillen tussen de dynamiekklassen betreffen vooral de schaal van de open ruimte. We gaan ervan uit deze schaalverschillen te handhaven.

\section{Verhogen kwaliteit}

Geschoren hagen door laten ontwikkelen tot struweelhagen. Struweelhagen ontwikkelen op de terrasrand, de overgang naar de lager gelegen uiterwaarden.

Hoogdynamisch: open onregelmatige blokverkaveling

- alle bestaande opgaande groene elementen erfbosjes ( $>0,5 \mathrm{ha}$ ), enkele robuuste singels, en beplanting langs doorgaande wegen maken deel uit van het casco;

- geschoren hagen op erfgrenzen en perceelranden rekenen we niet tot het casco;

- compensatie kan plaatsvinden overal binnen het rivierterrassenlandschap, maar bij voorkeur op een compensatielijn zoals op de terrasranden of in de uiterwaarden;

- gewenste kavelgrootte kavels open terrascomplex 10-30 ha.

Matig dynamisch: open onregelmatige blokverkaveling

- alle bestaande opgaande groene elementen erfbosjes (>0,5 ha), enkele robuuste singels, en beplanting langs doorgaande wegen maken deel uit van het casco;

- geschoren hagen op erfgrenzen en perceelranden rekenen we niet tot het casco;

- compensatie kan plaatsvinden overal binnen het rivierterrassenlandschap, maar bij voorkeur op een compensatielijn zoals op de terrasranden of in de uiterwaarden;

- gewenste kavelgrootte kavels open terrascomplex 3-10 ha.

\section{Laagdynamisch: open onregelmatige blokverkaveling}

- alle bestaande opgaande groene elementen erfbosjes ( $>0,5 \mathrm{ha}$ ), enkele robuuste singels, en beplanting langs doorgaande wegen maken deel uit van het casco;

- geschoren hagen op erfgrenzen en perceelranden rekenen we niet tot het casco;

- compensatie kan plaatsvinden overal binnen het rivierterrassenlandschap, maar bij voorkeur op een compensatielijn, zoals op de terrasranden of in de uiterwaarden;

- gewenste kavelgrootte kavels open terrascomplex 0,5-3 ha.

\subsection{Compensatie}

\subsubsection{Kwaliteitsladder}

Op de cascokaart staan lijnen die aangeven waar het landschap versterkt kan worden door compensatie. Om tot een versterking van het landschap te komen, is het van groot belang om bij elke locatie voor compensatie te kijken in welk landschapstype het ligt en van daaruit het plan voor de compensatie uit te werken in lijn met de visie per landschapstype, rekening houdend met de genoemde kwaliteitverhogende aspecten bij de keuze van het type element en gebruik te maken van streekeigen soortensamenstelling. Dat betekent in de praktijk een variatie in te compenseren landschapselementen: van gesloten bomenrijen tot elzensingels tot hakhoutsingels op steilranden. 
Een van de generieke bouwstenen is dat gestreefd wordt naar verhoging van de kwaliteit van de landschapselementen. Hieruit volgt een prioriteit (hoog-laag) met de voorkeur voor het type aan te leggen element. Robuuste landschapselementen, die bestaan uit een combinatie van een wallichaam, gevarieerde ondergroei en struiklaag en opgaande boomlaag, leveren de hoogste waarde in verhouding tot bijvoorbeeld een bomenrij zonder ondergroei. Houtsingels op een wallichaam komen in het studiegebied weinig voor en zijn daarom in de kwaliteitsladder niet apart onderscheiden. In de cascobenadering zitten daarom de volgende regels voor de uitvoering:

- Het te compenseren element moet minstens tot hetzelfde type element behoren of tot een element met een hogere waarde en heeft een minimale breedte (zie tabel 5.3 Kwaliteitsladder landschapselementen).

- Het te compenseren element wordt aangelegd met streekeigen en voor het landschapstype kenmerkende soorten. Voor de sortimentskeuze voor nieuw aan te leggen elementen wordt verwezen naar de tabel Groeiplaatsen Natuurlijke Boom en Struiksoorten in het objectiveringsdocument.

- Het te compenseren element wordt aangelegd volgens de 'objectiveringsregels landschapselementen' (Richtlijnen objectivering Casco Lochem Gemeente Lochem (2017)).

Het toevoegen van kwaliteit wordt beloond met een reductie op de te compenseren lengte van het element. De mate van reductie is opgenomen in de 'objectiveringsregels landschapselementen'.

Tabel 5.3 Kwaliteitsladder landschapselementen

\begin{tabular}{|c|c|c|}
\hline & andschapselement & $\begin{array}{l}\text { Ondergrens } \\
\text { breedte/oppervlakte } \\
\text { element }\end{array}$ \\
\hline 1 & Hakhoutsingel met struweelmantel en zoom (met of zonder wallichaam) & 4 meter \\
\hline 2 & Hakhout bosje $(<0,5$ ha) met struweelmantel en zoom & $250 \mathbf{m}^{2}$ \\
\hline 3 & Struweelhaag met zoom & 2 meter \\
\hline 4 & Hakhoutsingel met struweelmantel & 3 meter \\
\hline 5 & Hakhout bosje $(<0,5$ ha) met struweelmantel & $250 \mathbf{m}^{2}$ \\
\hline 6 & Struweelhaag /struweelrand & 1,5 meter \\
\hline 7 & Hakhoutsingel/elzensingel & 2,5 meter \\
\hline 8 & Knotbomenrij (wilg, els, es) & 1,5 meter \\
\hline 9 & Gesloten bomenrij (incl. laanbeplanting) & 2,5 meter \\
\hline 10 & Hakhout bosje (<0,5 ha) & $250 \mathrm{~m}^{2}$ \\
\hline 11 & Open bomenrij (incl. laanbeplanting) & 2,5 meter \\
\hline 12 & Geschoren haag of heg & 1 meter \\
\hline
\end{tabular}

Ook de ligging van het element speelt een belangrijke rol voor het functioneren van het landschap als samenhangend ecologisch systeem. Per landschapstype is daarom aangegeven waar de voorkeur ligt voor de positie van de te compenseren elementen op basis van de bouwstenen. Op de cascokaart zijn deze compensatie-elementen weergegeven en vormen samen met het landschappelijke casco van bestaande elementen een samenhangend groen netwerk van opgaande landschapselementen. 


\section{Resultaten}

\subsection{Landschap in ontwikkeling}

Figuur 6.1 geeft een overzicht van de landschapsdynamiek in het STEVIG-projectgebied. In tabel 6.1 is dit uitgewerkt in oppervlakten (ha/\%) per landschapstypen. Uit de analyse blijkt ten eerste dat $80 \%$ van het landschap matig (38\%) tot sterk (42\%) is veranderd. $20 \%$ van het landschap is als laagdynamisch geclassificeerd. In deze delen is weinig veranderd in de landschapsstructuur ten opzichte van de situatie rond 1900. De grootste veranderingen hebben zich met name voorgedaan in de oude agrarische cultuurlandschappen: de beekdalen, de oude broekontginningen, de essenlandschappen in zowel het dekzand- als het rivierengebied en de kampenlandschappen. Het kleinschalige groene karakter van deze landschappen heeft in de tijd plaatsgemaakt voor een relatief grootschalige openheid. Dit zien we met name terug in de beekdalen van de Eefsebeek, Heurnerbeek, Molenbeek en Dommerbeek. Een openheid die nu collectief wordt geadopteerd als een kenmerk van deze landschappen. De landschapsdiversiteit, de contrasten in het landschap op korte afstand, is hierdoor aan het verdwijnen. In veel gevallen is het alleen nog het reliëf dat voor het geoefende oog de landschappen markeert. Een positieve uitzondering binnen de oude cultuurlandschappen vormen de gebieden Groot Dochteren en het Landgoed Joppe. Ondanks dat de tijd en de ontwikkelingen in deze gebieden niet hebben stilgestaan, ademt het landschap hier nog de sfeer van het oorspronkelijke landschap. In deze gebieden is er samenhang tussen de groene structuur van lanen, singels en bosjes, de bodem en het reliëf.

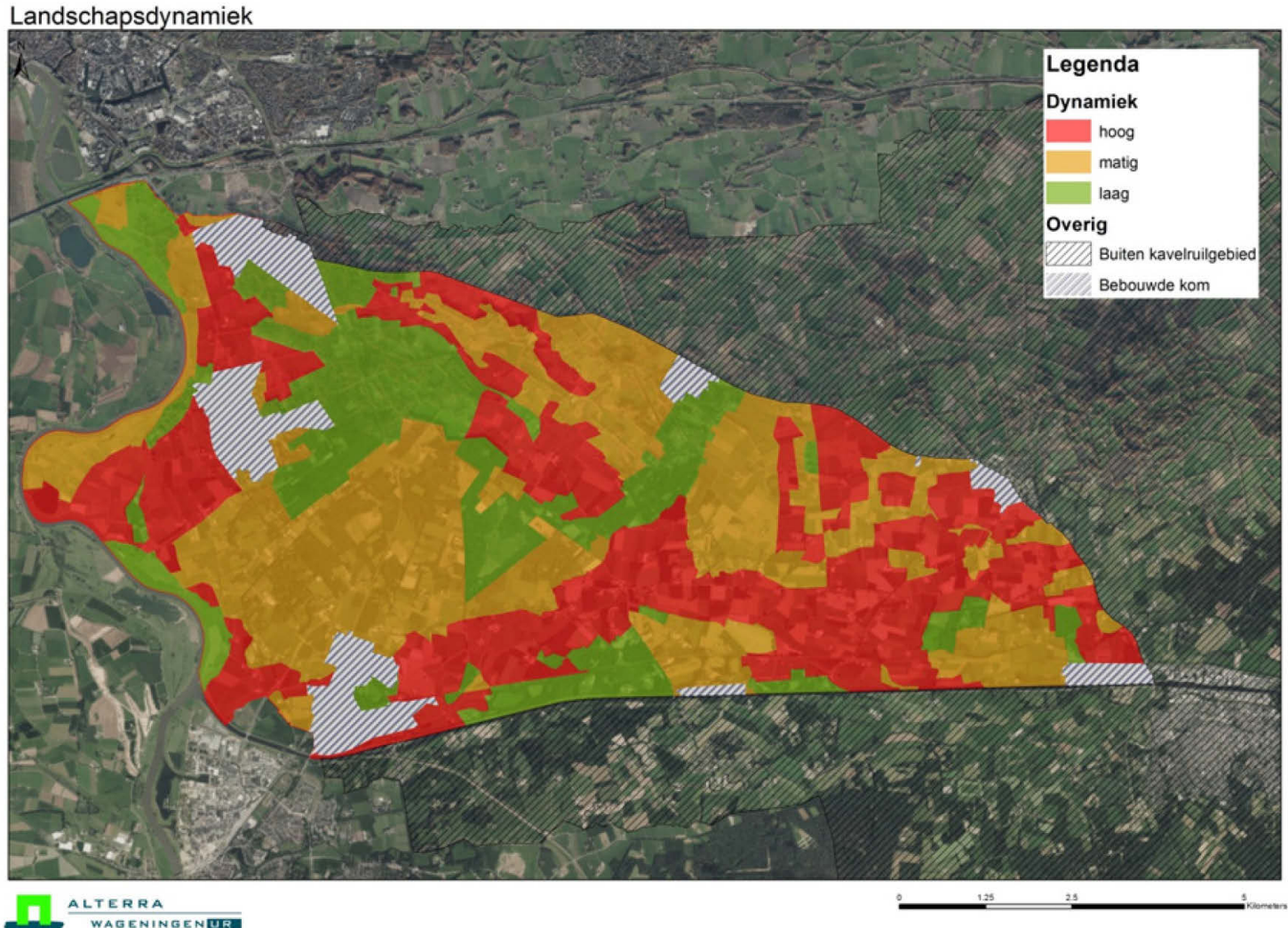

Figuur 6.1 Landschapsdynamiekkaart van het STEVIG-projectgebied Lochem-Laren-Epse-Eefde.

In tegenstelling tot veel andere gebieden in Oost-Nederland zijn het juist de jonge landschappen die in het STEVIG-gebied relatief weinig veranderingen hebben ondergaan waar het de ontginningsstructuur 
betreft. Na ontginning zijn de heidelandschappen maar zeer beperkt in agrarisch gebruik genomen, maar veelal bebost of men heeft gebruikgemaakt van de natuurlijke bosopslag op de heide. Grote delen van dit landschapstype zijn daardoor als laag- of matig dynamisch geclassificeerd. De structuur van het landschap die met de ontginning ontstond, is grotendeels bewaard gebleven in de vorm van een boslandschap met rechte ontginningslanen en verspreid enkele open ruimtes met landbouwpercelen. De Gorsselsche Heide in het gebied refereert aan de situatie van voor de ontginning. Een ander relatief jong landschap is het ontginningslandschap van het Emsbroek. Dit natte broekgebied is vanaf 1850 in ontginning gekomen. Kenmerkend voor dit gebied zijn de noordoost-zuidwest-ontginningsstructuren van wegen en waterlopen. Dit oorspronkelijk vrij open moerasgebied kent na de eerste drooglegging een fase waarin het gebied aan openheid verliest door natuurlijke ontwikkeling/aanleg van bos. Vervolgens heeft het gebied door het agrarisch gebruik de openheid gekregen die we nu van het gebied kennen, met enkele natte bosrestanten. Het gebied is als matig dynamisch geclassificeerd.

De uiterwaarden vormen een onderdeel van het landschap waarin zowel gebieden met hoge als matige en lage dynamiek voorkomen. De ontginningsstructuur van de Ravenswaarden, een opstrekkende verkaveling haaks op de rivier met struweelhagen en knotbomen op de kavelgrenzen, is als uniek voor het uiterwaardenlandschap van de IJssel te betitelen. In de zone dicht bij de dijk is de oorspronkelijke landschapsstructuur nagenoeg verdwenen. Dit gebied is als hoogdynamisch op de kaart gezet. Dit geldt ook voor het gebied van de zandwinplaats. De kern van het gebied met de IJsselheggen is als matig dynamisch geclassificeerd. De structuur is hier in hoofdlijnen nog goed aanwezig, maar kan versterkt worden. De laaggelegen uiterwaarden ten noorden en ten zuiden van de kern Ravenswaarden zijn als laagdynamisch gekarteerd. In deze gebieden volgt de structuur van het buitendijkse cultuurlandschap het natuurlijke reliëf van oude laaggelegen strangen en hogere oeverwallen en rivierterrassen. Omdat dit landschap in vroeger tijden ook al vrijgehouden werd van beplanting om de doorstroming van de rivier bij hoogwater te garanderen, is de openheid van nu vergelijkbaar met die in 1900.

Tabel 6.1 Oppervlakteverdeling van de landschapstypen en dynamiekklassen in het STEVIG-gebied (ha/\%).

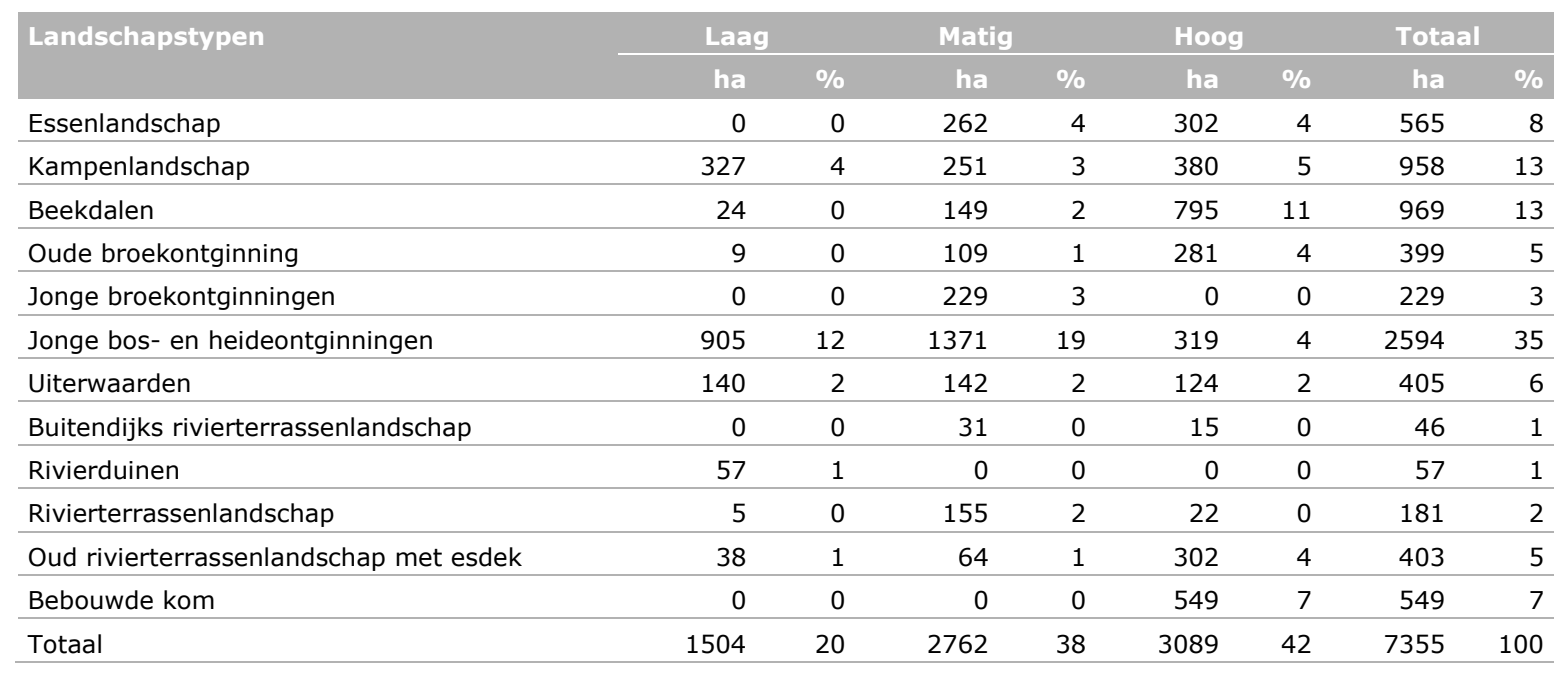

\section{Conclusie}

De conclusie uit deze analyse voor de uitvoering van de cascobenadering is dat met name in de hoogdynamische oude, agrarische cultuurlandschappen de focus zal liggen op het versterken van het landschap langs nieuwe landschapsstructuren. Voor de beekdalen en oude broekontginningen liggen daarvoor de kansen langs de natte infrastructuur. Aanleg (als compensatie) van beekbegeleidende (knot)bomenrijen en hakhoutsingels en hakhoutstruwelen en bosjes op de steilranden van het beekdal geven niet alleen een enorme impuls aan landschapskwaliteit ter plaatse, maar vergroten ook de ecologische samenhang in het gebied. Deze oost-west lopende natte structuren verbinden de landgoederen van Verwolde en Ampsen met de Gorsselsche heide en de uiterwaardennatuur langs de IJssel. 
Voor de drogere essen- en kampenlandschappen is de droge infrastructuur van wegen en paden geen optie, omdat deze structuur al beplant is en in de generieke bouwstenen is opgenomen dat er geen verplaatsing van landschapselementen naar wegbermen mag plaatsvinden. Een prima optie voor structuurversterking van deze landschappen vormen de steilranden van de essen en kampen. Veel van de steilrandbeplanting is in de loop van de tijd verdwenen. Herplant kan plaatsvinden zonder belemmeringen op te leveren voor de landbouwstructuur door rekening te houden met de positie en het type landschapselement, bijvoorbeeld laag hakhout of struweelhagen. Hiervoor geldt dus herstel van oude structuren in een nieuwe vorm.

In de matig dynamische gebieden kan het landschap versterkt worden door met de cascobenadering de bestaande 'gaten' in de landschapsstructuur aan te vullen. Dit geldt met name voor het IJsselheggengebied van de Ravenswaarden en het Emsbroek en delen van het kampenlandschap op de flanken van de beekdalen.

In de laagdynamische gebieden zijn geen duidelijke opgaven voor landschapsversterking geïdentificeerd.

\subsection{De cascokaart}

De cascokaart bestaat uit drie onderdelen (figuur 6.2). Ten eerste geeft de kaart weer wat wordt aangeduid als het 'raamwerk' van groene landschapselementen die gezamenlijk de structuur van het bestaande landschap dragen, het casco. Daarnaast worden de groene landschapselementen weergeven die geen onderdeel vormen van deze structuur. En ten slotte de lijnen waarlangs het landschap versterkt kan worden, zodat het landschap wint aan (ecologische) samenhang, kwaliteit en landschapsbeleving.

De in een groene kleur aangeduide eenheden op de kaart zijn de casco-elementen, de landschapselementen die niet verwijderd of verplaatst mogen worden.

De oranjerood gekleurde eenheden zijn de niet-casco-elementen. Deze elementen kunnen in het kader van de cascobenadering op de bestaande locatie worden verwijderd, maar dienen dan elders in het gebied op aangegeven locaties gecompenseerd te worden.

De gele lijnen op de kaart zijn ten slotte de locaties waar compensatie dient plaats te vinden. Deze locaties dragen bij aan de versterking van het landschap op een bepaalde locatie, maar zijn ook zo gekozen dat zij de landschapsstructuur en (ecologische) samenhang regionaal versterken. 


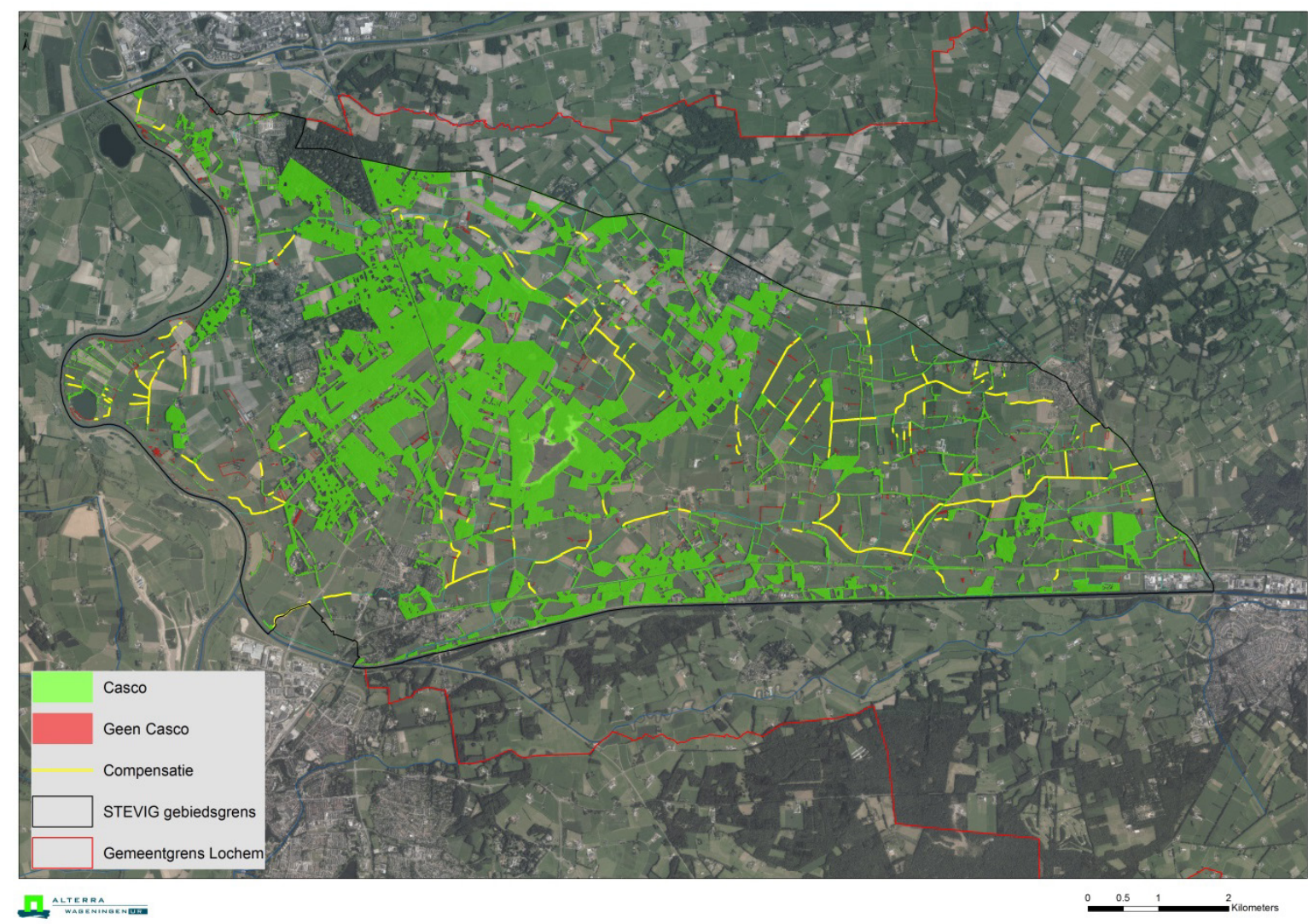

Figuur 6.2 Cascokaart van het STEVIG-gebied (april 2017).

Het casco van het landschap voor het STEVIG-gebied wordt in grote mate bepaald en vastgelegd door bestaand beleid, zoals de ligging van de Vogel- en Habitatrichtlijn gebieden (Natura 2000), het GeldersNatuurNetwerk (GNN), en de bestemmingen bos en natuur in het bestemmingsplan buitengebied van de gemeente Lochem (generieke bouwstenen). De bouwstenen per landschapstype, waarin de landschap-specifieke kenmerken worden beschreven, zijn gebruikt om het tot een samenhangend landschappelijk raamwerk te vormen. De indeling van de landschapsdynamiek is gebruikt om te bepalen op welk schaal deze samenhang actueel functioneert. In hoogdynamische landschappen zijn het alleen de hoofdstructuren die tot het casco gerekend zijn; in laagdynamische landschappen maken alle landschapsstructuren deel uit van het casco.

Het casco is zodanig vormgegeven dat aan de uitgangspunten van de minimale kavelgrootte voor effectief agrarisch gebruik vrijwel altijd wordt voldaan.

De landschapselementen die resteren, zijn geen onderdeel van het casco. Op de cascokaart zijn dit zowel elementen in het agrarisch gebied die buiten het casco vallen als beplanting rond erven die buiten de bestemmingen wonen, bedrijven of agrarisch bouwvlak vallen. Hoewel deze erfbeplantingen het beeld van het landschap in belangrijke mate bepalen - in hoogdynamische gebieden vormen zij soms de enige opgaande landschapselementen -, maken zij in veel gevallen geen deel uit van de samenhangende landschapsstructuur. Anderzijds zullen deze elementen niet actief worden ingezet voor structuurverbetering van de landbouw- en landschapsversterking, omdat er geen behoefte bestaat deze elementen in de directe woonomgeving te verplaatsen.

In het buitendijkse gebied zijn de elementen die binnen de stroombaan van het Programma Stroomlijn vallen niet tot het casco gerekend, met uitzondering van die elementen met een oriëntatie in de stroomrichting van het water.

Uit een visuele beoordeling van de kaart blijkt dat het aandeel te verplaatsen niet-casco-elementen, niet zijnde erfbeplanting, relatief gering is. Exacte kwantificering is niet mogelijk, omdat de elementen die niet tot het casco behoren voor een groot deel bestaan uit erfbeplanting, die geen onderdeel uitmaakt van de cascobenadering. Elementen die niet tot het casco behoren en daarom verplaatst mogen worden, komen vooral voor in de beekdallandschappen, oude en jonge broekontginningen en 
enkele kleine gebieden hoogdynamische bos en heideontginningslandschap. De uiterwaarden laten we hier in verband met de afwijkende situatie buiten beschouwing.

Veel van de landschappen zijn in de loop der jaren dermate opgeschaald dat landschapselementen op dit moment niet de belemmerende factor zijn om tot een structuurverbetering van de landbouw te komen. Op de enkele plaatsen waar dit wel het geval is, biedt het casco-instrument voldoende houvast om voor die situaties tot een voor landbouw en landschap adequate oplossing te komen.

Vergelijken we daarmee het aandeel gele compensatielijnen, dan is de behoefte aan landschapsversterking voor deze gebieden waarschijnlijk veel groter dan het aanbod aan te verplaatsen landschapselementen hierin kan voorzien. In tabel 6.2 is een overzicht gegeven van de behoefte aan landschapsstructuurversterking per landschapstype en dynamiekklasse in meters. De totale lengte compensatielocaties bedraagt ruim $30 \mathrm{~km}$. Het grootste deel daarvan, ruim $13 \mathrm{~km}$, wordt ingenomen door de beekdalen. De oost-west georiënteerde beeklopen van de Dommerbeek en de Eefsche-Harfensche Beek en Molenbeek bieden de grootste kansen voor landschapsherstel. Met name in de beekdalen is het landschap in de loop der jaren sterk veranderd (hoge dynamiek). Het model van het waterschap Rijn en IJssel voor Agrarisch Waterbeheer (zie par. 3.4) biedt uitstekende kansen hiervoor.

Potenties voor landschapsversterking in de uiterwaarden liggen er vooral in het IJsselheggenlandschap door compensatie van landschapselementen die in het kader van Programma Stroomlijn moeten verdwijnen. Aanleg van struweelhagen kan vooral op de hooggelegen delen van de uiterwaarden binnen het Gelders NatuurNetwerk plaatsvinden.

De compensatielijnen in de (oude) rivierterrassen met en zonder esdek zijn gericht op het onderling verbinden van de rivierduinlandschappen langs de terrasranden en het verbinden van binnendijkse natuur met het buitendijkse gebied. Hier ontbreken op dit moment belangrijke schakels in het landschap.

Een derde belangrijke categorie vormen de compensatielijnen op de steilranden van het Kampenlandschap. In veel gevallen zijn deze ook oost-west georiënteerd en vormen zij een samenhangende structuur met de compensatielijnen langs de waterlopen in de beekdalen.

In het jonge broekontginningen-landschap is bewust gekozen om de potentiële compensatie gering te houden in verband met het behouden van het open karakter van het landschap.

Tabel 6.2 Lengte potentiële compensatielocaties per landschapstype en dynamiekklasse ( $m$ ).

\begin{tabular}{|c|c|c|c|c|}
\hline Landschapstype & hoog & matig & laag & Totaal \\
\hline Beekdalen & 12017 & 872 & 135 & 13023 \\
\hline Uiterwaarden & 1825 & 1043 & 1150 & 4019 \\
\hline Kampenlandschap & 1060 & 1189 & 822 & 3070 \\
\hline Jonge broekontginningen & & 2255 & & 2255 \\
\hline Essenlandschap & 1054 & 363 & & 1418 \\
\hline Rivierterrassenlandschap & & 453 & 1 & 454 \\
\hline Buitendijks rivierterrassenlandschap & 141 & 223 & & 364 \\
\hline Oud rivierterrassenlandschap met esdek & 319 & & & 319 \\
\hline
\end{tabular}




\section{$7 \quad$ Conclusies en aanbevelingen}

De cascoanalyse leidt tot de volgende conclusies:

$\mathrm{Er}$ is voldoende ruimte voor structuurversterking van de landbouw in de gebieden die niet onder het bestaande reguliere (inter)nationaal natuur- en landschapsbeleid vallen (GNN, N2000, Nationaal landschap). In deze zogenaamde 'witte' gebieden vormt het huidige landschap in de regel geen belemmering voor een structuurversterking van de landbouw (al dan niet met kavelruil). De omvang van de percelen, dat wil zeggen de ruimte tussen de landschapselementen, is in het algemeen voldoende voor een effectieve en efficiënte landbouw binnen de kaders die in het gebiedsproces van de cascobenadering zijn afgesproken. In situaties waar dit niet het geval is voorziet de cascobenadering in een adequate oplossing.

De casco-analyse heeft aan het licht gebracht dat er met name in de 'witte' gebieden vanuit het landschap geredeneerd een behoefte is aan landschapsstructuurversterking. Deze structuurversterking is niet alleen gericht op het verbeteren van ecologische samenhang van het gehele gebied, maar ook het verbeteren van de landschapskwaliteit en -beleving. De diversiteit van de landschappen is aan slijtage onderhevig. De oost-west georiënteerde structuur van beekdalen kan in meerdere opzichten en schaalniveaus de schakel vormen tussen min of meer geïsoleerde onderdelen van het landschap. Daarnaast bieden de beeklopen zelf een unieke kans om landschapsstructuren met kwaliteit te ontwikkelen (gradiëntsituaties nat-droog en voedselrijk-voedselarm) die voor vele soorten een geschikt habitat bieden en als corridor tussen de verschillende leefgebieden kunnen functioneren.

Het model van het waterschap Rijn en IJssel voor agrarisch natuurbeheer langs de grote doorgaande beken die een lage KRW-ambitie hebben, kan een grote bijdrage leveren in het kader van de landschapsstructuurverbetering. Ook voor de landbouw kan dit model aantrekkelijk zijn, omdat het tot een (bescheiden) areaal vergroting kan leiden.

Uitvoering geven aan de cascobenadering in het kader van de vrijwillige kavelruil Lochem-Laren-EpseEefde, voorziet hoogstwaarschijnlijk niet in een voldoende aantal te verplaatsen landschapselementen waarmee de landschapsstructuur voldoende versterkt kan worden. Het zal tot lokale structuurverbeteringen beperkt blijven. De compensatielijnen bieden voor deze kleine aanpassingen wel voldoende kader om de geschikte locaties te vinden.

Hoewel de cascobenadering niet gezien mag worden als een landschapsplan, menen wij dat we in deze cascoanalyse voldoende in beeld hebben gebracht waar het landschap in grote lijnen aan kwaliteit kan winnen. Wij zijn van mening dat landschap in het gebied Lochem-Laren-Epse-Eefde enorm aan kwaliteit kan winnen als de landschapsstructuren langs de oost-west lopende beeksystemen worden hersteld. Naar onze verwachting zal de vrijwillige kavelruil in dit gebied onvoldoende perspectief bieden voor landschapsherstel op deze schaal. Daarom roepen wij de gebiedspartijen op om energie te genereren voor het landschap en gezamenlijk initiatieven te ontwikkelen gericht op een duurzame integrale landschapsstructuurversterking. De gemeente Lochem kan hierin faciliteren met haar subsidieregeling GPL. Eigenaren ontvangen een financiële bijdrage om nieuwe landschapselementen te realiseren.

Een deel van het casco ligt buiten de leefgebieden van het nieuwe stelsel Agrarisch Natuur- en Landschapsbeheer (ANLB). Voor beheersvergoedingen van deze casco-elementen zal een andere oplossing gezocht moeten worden.

De cascobenadering werkt alleen als de gemeente actief het gedachtegoed uitdraagt. Dat betekent enerzijds invulling geven aan haar regierol daar waar gebiedspartijen in lijn met de cascobenadering initiatieven ontwikkelen om de landschapsstructuur te versterken en anderzijds handhaven, daar waar tegen de regels in landschapselementen worden aangetast of op een onjuiste wijze worden gecompenseerd. 
De gemeente is geen bevoegd gezag voor opgaand groen dat valt onder de Boswet en vanaf 1 juli 2016 onder de Wet natuurbescherming. Zonder aanvullend beleid betekent dit dat de gemeente het cascobeleid niet kan uitvoeren voor die landschapselementen. Een oplossing kan zijn de provincie te vragen het cascobeleid op te nemen in een provinciale verordening. Die bevoegdheid heeft de provincie in de Wet natuurbescherming namelijk gekregen in artikel 4.2, lid 3 als het gaat om een verbod om casco-elementen te vellen: Gedeputeerde Staten kunnen het vellen van houtopstanden telkens voor ten hoogste vijf jaar verbieden ter bescherming van bijzondere natuur- of landschapswaarden. En in artikel 4.3, lid 3 als het gaat om richtlijnen voor het herplanten: Provinciale staten kunnen bij verordening regels stellen over de bosbouwkundig verantwoorde wijze van herbeplanting, bedoeld in het eerste lid.

Op het moment van afronding van de cascobenadering was het proces van de vrijwillige kavelruil Lochem-Laren-Epse-Eefde nog niet zover gevorderd dat de uitkomsten van de cascobenadering in het gebiedsproces konden worden ingebracht. Om te toetsen wat de cascobenadering kan bijdragen aan het kavelruilproces, wordt aanbevolen een of meerdere proefsessies te organiseren die aansluiten bij initiatieven die in de streek leven.

Ten slotte: de cascobenadering is een denkwijze en geen blauwdruk voor het landschap. Het beoogt het bewustzijn te vergroten dat landschap dynamisch is. Doordat samen met de gebiedspartijen een kader met spelregels en een landschapsstructuur op hoofdlijnen is vastgelegd, wordt ruimte geboden aan ontwikkelingen die zowel voor de landbouw als het landschap positief kunnen uitwerken. Dat vraagt van alle partijen een houding die verdergaat dan het individuele belang, en ook recht doet aan de maatschappelijke opgave voor een gezonde leefomgeving voor mens en natuur en een mooi landschap. 


\section{Literatuur}

Bont, Chris de, 2008. Vergeten land, ontginning, bewoning en waterbeheer in de West-Nederlandse veengebieden (800-1350). Proefschrift Wageningen Universiteit, Wageningen. 2 dl. (652 p.)

Dirkx, G.H.P. \& W. Nieuwenhuizen, 2013. HISTLAND; Historisch-landschappelijk informatiesysteem. Wageningen, Wettelijke Onderzoekstaken Natuur \& Milieu, WOt-werkdocument 331.36 blz.; 8 ref.; 5 bijl.

Duenk, F.H.J. \& C.A.M. ten Cate, 2009. Landschapsontwikkelingsvisie Bronckhorst-Lochem-Zutphen. Royal Haskoning, Enschede.

Gemeente Lochem, 2010. Bestemmingsplan Buitengebied.

Gemeente Lochem, 2017. Richtlijnen objectivering Casco Lochem.

Maas, G.J. \& Boers, J., 2010. Goed boeren in een nationaal landschap : hoe het landschap in Noordoost-Twente kan profileren van schaalvergroting in de landbouw, uitwerking van de cascobenadering in de gemeente Tubbergen, Alterra, Alterra-rapport 2087, Wageningen.

Nieuwenhuizen, W. \& G.J. Maas, 2012. Cascobenadering in Noordoost-Twente. Wageningen, Alterra, Alterra-rapport 2275, Wageningen.

Notitie: Naar een benchmark voor Basiskwaliteit natuur en landschap en bijzondere natuurkwaliteit, 2015. Vorden. (https://www.gemeenteberkelland.nl/bis/dsresource?objectid=7cdbf820-877c4a83-9a6a-55d14b1cac0f\&type=PDF).

Stortelder, A., in prep. Basiskwaliteit Landschap.

Vries, F. de; Groot, W.J.M. de; Hoogland, T.; Denneboom, J., 2003. De Bodemkaart van Nederland digitaal; toelichting bij inhoud, actualiteit en methodiek en korte beschrijving van additionele informatie. Wageningen, Alterra, Alterra-rapport 811, Wageningen.

Zoon buro voor ecologie, 2009. Natuurkansen in Lochem. Aanwezige natuurwaarden en potenties voor ontwikkeling daarvan in het buitengebied van de gemeente Lochem. Met handleiding voor gebruik in de praktijk. 


\section{Bijlage 1 Bestemmingsplan Buitengebied}

Algemene aanduidingsregels landschapstypen (40.2):

Beleid en kernkwaliteiten (40.2.1):

Ter plaatse van de aanduiding 'overige zone' - landschapstype a t/m $\mathrm{h}$ is het beleid gericht op de instandhouding en de ontwikkeling van het landschap met de volgende kernkwaliteiten:

a. Beekdallandschap: oost-west stromende beken, open dalen met veel hoogteverschillen, wegen, bebouwing en hoog opgaande beplanting evenwijdig aan dan wel haaks op de beken en gesitueerd aan de rand van het beekdal op de overgang naar andere landschapstypen;

b. Bos- en landgoederenlandschap: parkachtige historische tuinen, oude boerderijen en landerijen, bos en houtwallen, afwisseling bos met kleinschalig landschap, boomgroepen en solitaire bomen in weides, lanen met dubbele bomenrijen;

c. Essenlandschap: microreliëf in de vorm van grote essen en steilranden, perceelrandbeplanting, houtwallen en houthakbosjes, onregelmatige verkaveling, grillige wegenstructuur, oude boerderijen en open essen en enken;

d. Kleinschalig kampenlandschap: kleinschalig landschap, microreliëf in de vorm van eenmansessen en steilranden, perceelrandbeplanting, houtwallen en houthakbosjes, grillige wegenstructuur met beplanting en open essen en enken;

e. Open broekgebied: vlak en open landschap met een regelmatig verkavelingspatroon, sloten, rechte wegen en grote open ruimten met weinig beplanting in de vorm van kleine boselementen en houtwallen;

f. Rivierenlandschap van het IJsseldal: openheid, natuurlijk karakter met nauwelijks bebouwing, afwisseling van hoge en lage delen, stroomruggen, stangen, zandgaten en wielen, zomer- en winterdijk;

g. Stuwwal: het macroreliëf van de stuwwal, doorzichten, perceelrandbeplanting, de combinatie van bos op de oost- en westhelling en een krans van open essen en enken.

Algemene aanduidingsregels essen en enken (40.3)

Ter plaatse van de aanduiding 'overige zone - essen en enken' is het beleid gericht op het open houden van de essen en enken en is in de bestemmingen Agrarisch in Artikel 3 en Agrarisch met waarden in Artikel 4 aangegeven of er bij het verlenen van afwijkingen of omgevingsvergunningen voor het uitvoeren van een werk - geen bouwwerk - of van werkzaamheden, en bij wijziging van het bestemmingsplan aan dit beleid moet worden getoetst en op welke wijze.

Algemene aanduidingsregels beschermingszone natte landnatuur (40.4)

Ter plaatse van de aanduiding 'overige zone - beschermingszone natte landnatuur' is het beleid gericht op de instandhouding van natte natuur en is in de bestemmingen Agrarisch en Agrarisch met waarden aangegeven of er bij het verlenen van afwijkingen of omgevingsvergunningen voor het uitvoeren van een werk - geen bouwwerk - of van werkzaamheden, en bij de wijziging van het bestemmingsplan aan dit beleid moet worden getoetst en op welke wijze.

Algemene aanduidingsregels Weidevogelgebied (40.5)

Ter plaatse van de aanduiding 'overige zone - weidevogelgebied' is het beleid gericht op de instandhouding van het weidevogelgebieden en is in de bestemmingen Agrarisch in Artikel 3 en Agrarisch met waarden in Artikel 4 aangegeven of er bij het verlenen van afwijkingen of omgevingsvergunningen voor het uitvoeren van een werk - geen bouwwerk - of van werkzaamheden, en bij wijziging van het bestemmingsplan aan dit beleid moet worden getoetst en op welke wijze. 
Tabel B1 Bouwstenen cascobenadering afgeleid uit het Bestemmingsplan buitengebied Gemeente Lochem.

\begin{tabular}{|c|c|}
\hline Landschapstype & Bouwsteen \\
\hline Essenlandschap & $\begin{array}{l}\text { - Behoud afwisseling (open) essen en beplanting op steilranden } \\
\text { - Behouden karakteristieke beplanting op de randen van de es/enk } \\
\text { - Behoud grillige structuur (onregelmatige blokverkaveling, gebogen grenzen) } \\
\text { - Op essen en enken geen aanleg van landschapselementen of met uitzondering van de } \\
\text { esranden en lage gronden } \\
\text { - Wegbeplanting versterken }\end{array}$ \\
\hline Kampenlandschap & $\begin{array}{l}\text { - Behoud kleinschalig beeld } \\
\text { - Behoud grillige structuur (onregelmatige blokverkaveling, gebogen grenzen) } \\
\text { - Behoud steilranden \& microreliëf } \\
\text { - Beplanten van steilranden } \\
\text { - Wegbeplanting }\end{array}$ \\
\hline Beekdallandschap & $\begin{array}{l}\text { - Behoud openheid } \\
\text { - Oriëntatie hoog opgaande nieuwe beplanting oost-west } \\
\text { - Oriëntatie lage beplanting haaks op de beekloop } \\
\text { - Geen bebossing op lage gronden i.v.m. met behoud openheid }\end{array}$ \\
\hline $\begin{array}{l}\text { Broekontginningen- } \\
\text { landschap } \\
\text { (Open broekgebied) }\end{array}$ & $\begin{array}{l}\text { - Behoud openheid } \\
\text { - Windsingels en hagen die perceelspatroon volgen langs wegen situeren (voorkeur) } \\
\text { - Geen aanleg van bossen } \\
\text { - Wegbeplanting }\end{array}$ \\
\hline
\end{tabular}


Wageningen Environmental Research Postbus 47

6700 AA Wageningen

T 0317480700

www.wur.nl/environmental-research

Wageningen Environmental Research Rapport 2810

ISSN 1566-7197
De missie van Wageningen University \& Research is 'To explore the potential of nature to improve the quality of life'. Binnen Wageningen University \& Research bundelen Wageningen University en gespecialiseerde onderzoeksinstituten van Stichting Wageningen Research hun krachten om bij te dragen aan de oplossing van belangrijke vragen in het domein van gezonde voeding en leefomgeving. Met ongeveer 30 vestigingen, 5.000 medewerkers en 10.000 studenten behoort Wageningen University \& Research wereldwijd tot de aansprekende kennisinstellingen binnen haar domein. De integrale benadering van de vraagstukken en de samenwerking tussen verschillende disciplines vormen het hart van de unieke Wageningen aanpak. 



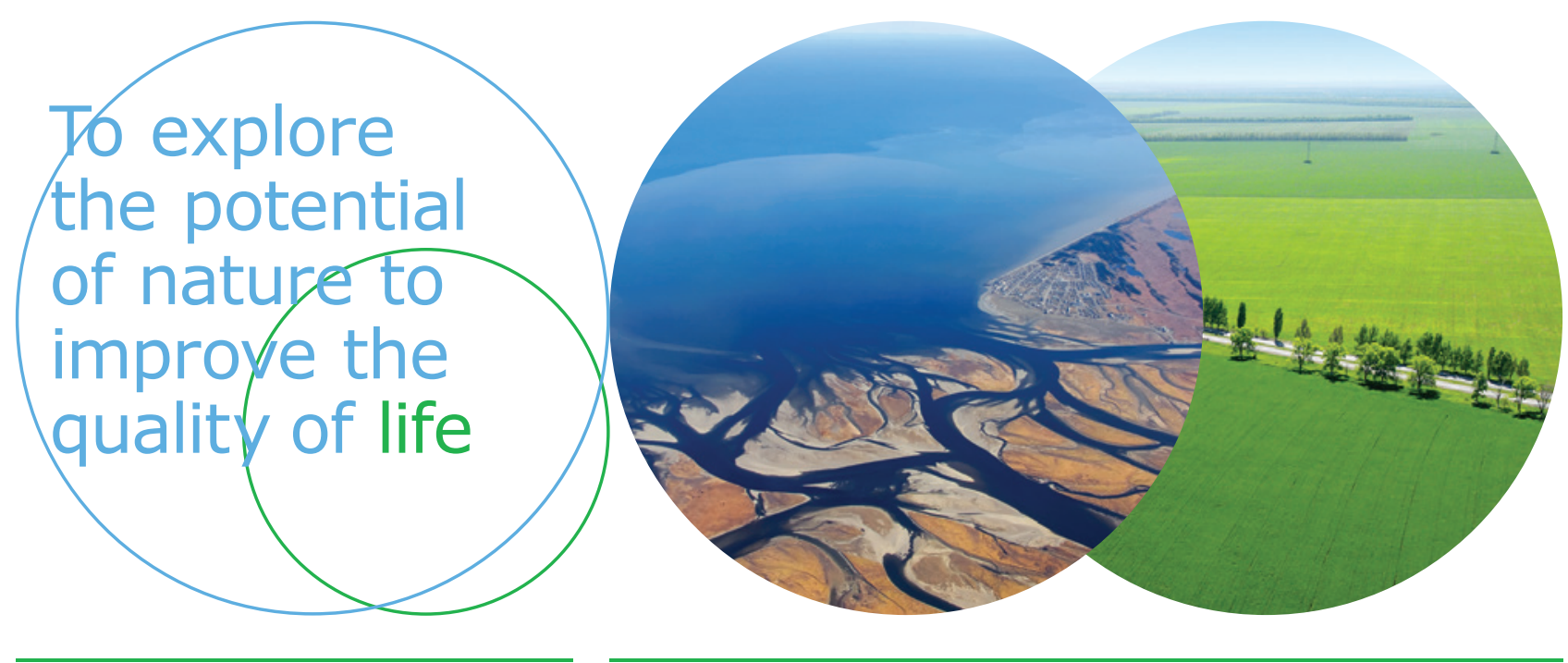

Wageningen Environmental Research Postbus 47

$6700 \mathrm{AB}$ Wageningen

T 317480700

www.wur.nl/environmental-research

Rapport 2810

ISSN 1566-7197
De missie van Wageningen University \& Research is 'To explore the potential of nature to improve the quality of life'. Binnen Wageningen University \& Research bundelen Wageningen University en gespecialiseerde onderzoeksinstituten van Stichting Wageningen Research hun krachten om bij te dragen aan de oplossing van belangrijke vragen in het domein van gezonde voeding en leefomgeving. Met ongeveer 30 vestigingen, 5.000 medewerkers en 10.000 studenten behoort Wageningen University \& Research wereldwijd tot de aansprekende kennisinstellingen binnen haar domein. De integrale benadering van de vraagstukken en de samenwerking tussen verschillende disciplines vormen het hart van de unieke Wageningen aanpak. 